\title{
Estimated Water Withdrawals and Use in Illinois, 1990
}

By Charles Avery

U.S. GEOLOGICAL SURVEY

Open-File Report 96-396

Prepared in cooperation with the

ILLINOIS STATE WATER SURVEY

Urbana, Illinois

1996

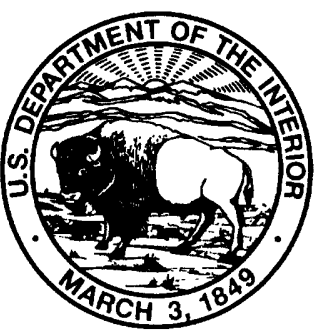




\title{
U.S. DEPARTMENT OF THE INTERIOR BRUCE BABBITT, Secretary
}

\author{
U.S. GEOLOGICAL SURVEY
}

Gordon P. Eaton, Director

For addtional information write to:

District Chief

U.S. Geological Survey

102 E. Main St., 4th Floor

Urbana, Illinois 61801
Copies of this report can be purchased from:

U.S. Geological Survey

Branch of Information Services

Box 25286

Denver, CO 80225-0046 


\section{CONTENTS}

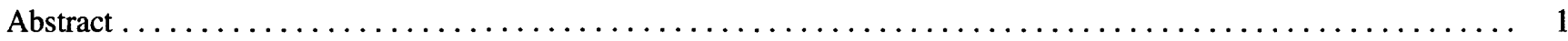

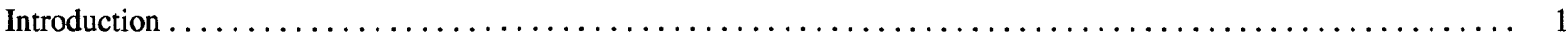

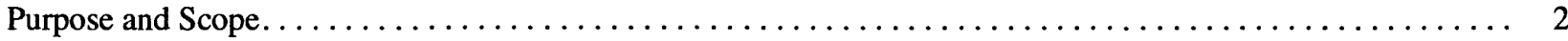

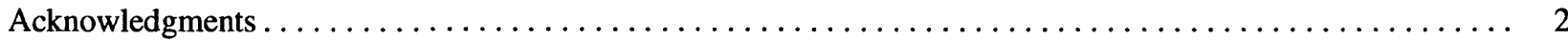

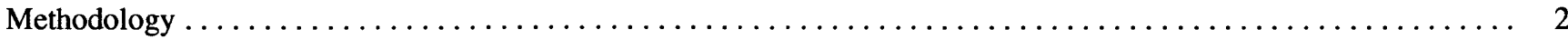

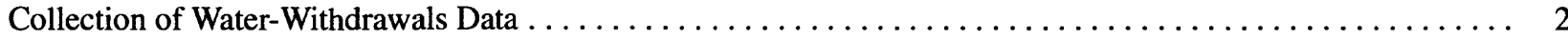

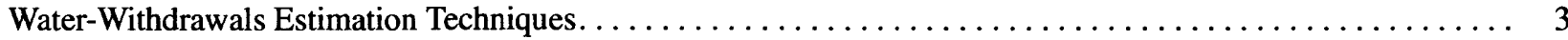

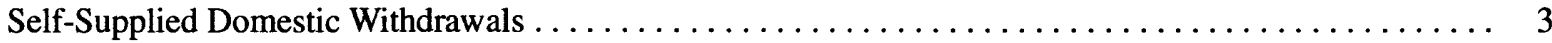

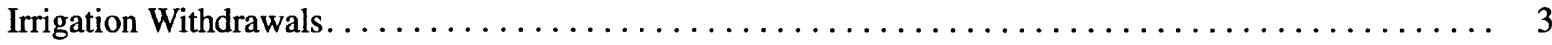

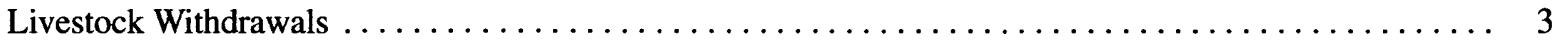

Estimated Water Withdrawals and Use in Illinois, $1990 \ldots \ldots \ldots \ldots \ldots \ldots \ldots$

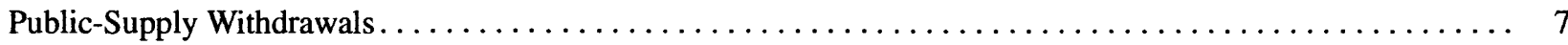

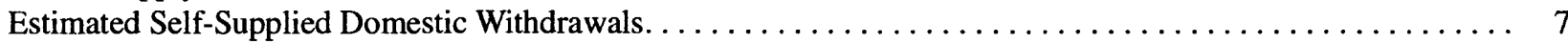

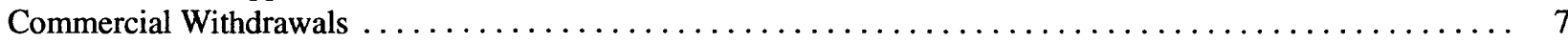

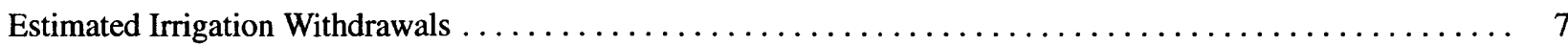

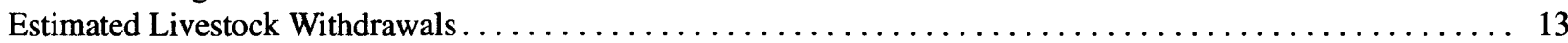

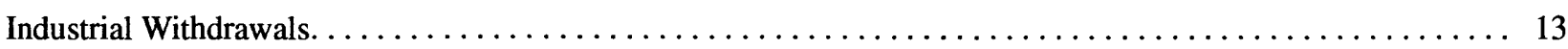

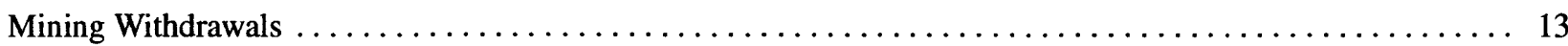

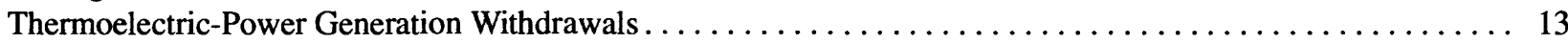

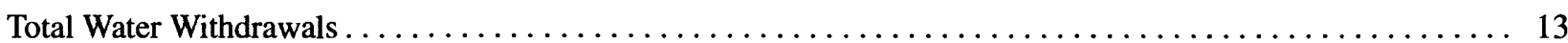

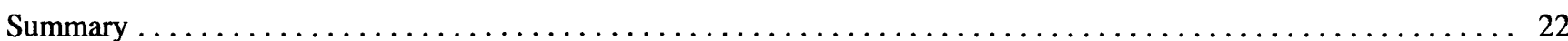

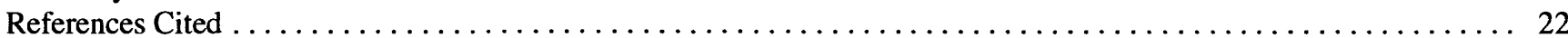

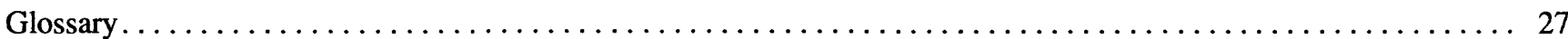

\section{FIGURES}

1-17. Maps showing:

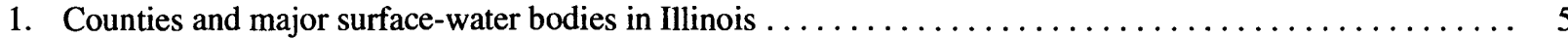

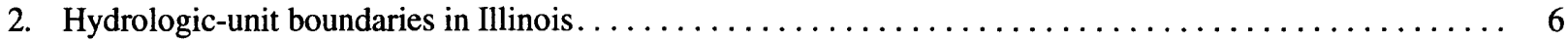

3. Public-supply withdrawals of ground water in Illinois, by county, $1990 \ldots \ldots \ldots$

4. Public-supply withdrawals of surface water in Illinois, by county, $1990 \ldots \ldots \ldots \ldots$

5. Estimated self-supplied domestic withdrawals of water in Illinois, by county, $1990 \ldots \ldots \ldots$

6. Self-supplied commercial withdrawals of ground water in Illinois, by county, $1990 \ldots \ldots \ldots \ldots$

7. Self-supplied commercial withdrawals of surface water in Illinois, by county, $1990 \ldots \ldots \ldots \ldots$

8. Estimated irrigation withdrawals of water in Illinois, by county, $1990 \ldots \ldots \ldots \ldots \ldots$

9. Estimated livestock and animal specialties withdrawals of water in Illinois, by county, 1990 . . . . . . 15

10. Self-supplied industrial withdrawals of ground water in Illinois, by county, $1990 \ldots \ldots \ldots$

11. Self-supplied industrial withdrawals of surface water in Illinois, by county, $1990 \ldots \ldots \ldots 17$

12. Mining withdrawals of ground water in Illinois, by county, $1990 \ldots \ldots \ldots \ldots \ldots$

13. Mining withdrawals of surface water in Illinois, by county, $1990 \ldots \ldots \ldots \ldots$

14. Self-supplied thermoelectric-power withdrawals of ground water in Illinois, by county, $1990 \ldots \ldots$. . . . . 20

15. Self-supplied thermoelectric-power withdrawals of surface water in Illinois, by county, 1990 . . . . . . 21

16. Total withdrawals of ground water in Illinois, by county, $1990 \ldots \ldots \ldots \ldots \ldots \ldots$

17. Total withdrawals of surface water in Illinois, by county, $1990 \ldots \ldots \ldots \ldots \ldots \ldots$

18. Pie diagrams showing surface-water, ground-water, and total water withdrawals by water-use

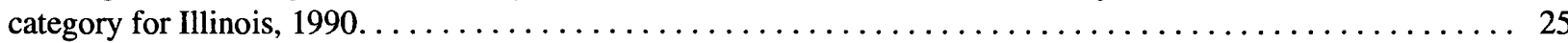


1. Public-supply withdrawals and domestic water use in Illinois, by county, 1990 .

2. Public-supply withdrawals and domestic water use in Illinois, by hydrologic unit, 1990 ................................. 33

3. Population served by public-supply facilities and self-supplied population in Illinois, by county, $1990 \ldots \ldots \ldots \ldots . . .34$

4. Population served by public-supply facilities and self-supplied population in Illinois, by hydrologic unit, 1990

5. Commercial self-supplied withdrawals and deliveries from public-supply facilities for commercial use in Illinois, by county, 1990

6. Commercial self-supplied withdrawals and deliveries from public-supply facilities for commercial use in Illinois, by hydrologic unit, 1990

7. Estimated irrigation water withdrawals, irrigated land, and estimated water withdrawals for livestock and animal specialties in Illinois, by county, 1990

8. Estimated irrigation water withdrawals, irrigated land, and estimated water withdrawals for livestock and animal specialties in Illinois, by hydrologic unit, 1990.

9. Industrial self-supplied withdrawals and deliveries from public-water facilities for industrial use in Illinois, by county, 1990

10. Industrial self-supplied withdrawals and deliveries from public-water facilities for industrial use in Illinois, by hydrologic unit, 1990

11. Mining withdrawals and consumptive use in Illinois, by county, 1990

2. Mining withdrawals and consumptive use in Illinois, by hydrologic unit, 1990 ...

13. Thermoelectric-power self-supplied withdrawals, deliveries from public-supply facilities for thermoelectric-power generation, consumptive use, and power generated in Illinois, by county, 1990 .

14. Thermoelectric-power self-supplied withdrawals, deliveries from public-supply facilities for thermoelectric-power generation, consumptive use, and power generated in Illinois, by hydrologic unit, 1990

15. Total withdrawals in Illinois, by county, 1990 .

16. Total withdrawals in Illinois, by hydrologic unit, 1990

\section{CONVERSION FACTORS}

\begin{tabular}{rcl}
\hline Multiply & By & To obtain \\
\hline foot (ft) & 0.3048 & meter \\
inch (in.) & 25.4 & millimeter \\
million gallons per day (Mgal/d) & 3,785 & cubic meter per day \\
gallon per day (gal/d) & 0.003785 & cubic meter per day \\
gigawatt-hour (GWh) & $3,413 \times 10^{9}$ & British thermal unit \\
\hline
\end{tabular}




\title{
Estimated Water Withdrawals and Use in Illinois, 1990
}

\author{
By Charles Avery
}

\section{Abstract}

The total amount of water withdrawn in Illinois during 1990 was about 18,016 million gallons per day $(\mathrm{Mgal} / \mathrm{d})$. This amount was about $740 \mathrm{Mgal} / \mathrm{d}$ less than in 1988 . The total water withdrawn for thermoelectric-power generation was about $15,170 \mathrm{Mgal} / \mathrm{d}$; about $370 \mathrm{Mgal} / \mathrm{d}$ was consumptively used. About $936 \mathrm{Mgal} / \mathrm{d}$, or 33 percent, of the total water withdrawn in Illinois during 1990 was ground water, excluding withdrawals for thermoelectricpower generation; about $1,911 \mathrm{Mgal} / \mathrm{d}$ of surface water was withdrawn and used, excluding withdrawals for thermoelectric-power generation. Seventy-four percent of the total surface water, excluding withdrawals for thermoelectric-power generation, was withdrawn by public-supply facilities. The next largest use of surface water was for self-supplied industrial withdrawals. Forty-seven percent of the total ground water was withdrawn by public-supply facilities. The next largest use of ground water was for irrigation. About $25 \mathrm{Mgal} / \mathrm{d}$ of the total ground water withdrawn was saline. Sixty-five percent of the total water withdrawn, excluding thermoelectric withdrawals, in Illinois during 1990 was for public-supply facilities. The next largest users of the total water withdrawn was for self-supplied withdrawals by industries and for irrigation.

Water withdrawn and delivered from public-supply facilities in Illinois during 1990 totaled about 1,859 Mgal/d. Surface water and ground water were the sources for about 1,415 and $444 \mathrm{Mgal} / \mathrm{d}$, respectively, of the withdrawals for public supply. The total water obtained from Lake Michigan for public-water supply was about $1,146 \mathrm{Mgal} / \mathrm{d}$. About $115 \mathrm{Mgal} / \mathrm{d}$ was withdrawn for self-supplied domestic purposes. Total selfsupplied withdrawals and deliveries from publicwater facilities for commercial use were about $672 \mathrm{Mgal} / \mathrm{d}$. About $173 \mathrm{Mgal} / \mathrm{d}$ was self supplied by the commercial establishments. Total irrigation water withdrawals were about $78 \mathrm{Mgal} / \mathrm{d}$. Total estimated livestock withdrawals were about $63 \mathrm{Mgal} / \mathrm{d}$. Total self-supplied withdrawals and deliveries from public-supply facilities for industrial purposes were about $728 \mathrm{Mgal} / \mathrm{d}$. About $464 \mathrm{Mgal} / \mathrm{d}$ was self-supplied withdrawals by industrial facilities. A total of about $94 \mathrm{Mgal} / \mathrm{d}$ was withdrawn during mining activities. A total of about $33 \mathrm{Mgal} / \mathrm{d}$ was withdrawn during mining from ground-water sources; about $25 \mathrm{Mgal} / \mathrm{d}$ of the ground water withdrawn was saline.

\section{INTRODUCTION}

Water-use information aids in the planning and management of water resources in Illinois. Water-use data serve the needs of governmental agencies, public water-supply operators, water-resource managers, and researchers for assessing current water-use patterns and anticipating future water demands. This report, prepared in cooperation with the Illinois State Water Survey (ISWS), provides statewide water-use data for 
1990. The last comprehensive water-use report for Illinois provides data for 1988 (Avery, 1995).

The State of Illinois has an abundant but finite supply of surface water ${ }^{1}$ and ground water. The State is bounded by major surface-water resources; the Mississippi River on the western border, the Ohio and Wabash Rivers on the south and southeast, and Lake Michigan on the northeast (fig. 1). Major tributaries to the rivers bounding the State are the Illinois, Kaskaskia, Rock, Big Muddy, Embarras, and Kankakee Rivers. No saline surface-water sources are found in Illinois. Ground water also is a widely available freshwater resource in Illinois. Major aquifers underlying Illinois include the saturated unconsolidated sand and gravel deposits, the Pennsylvanian-Mississippian aquifer, Silurian aquifer, and the Cambrian-Ordovician aquifer (U.S. Geological Survey, 1985).

Definition of terms is critical in understanding water-use data. Water-use terms utilized in this report are presented in the glossary (at the back of the report). Definitions of water-use terms in the glossary are from Solley and others (1993). This report deals primarily with water withdrawals. Some withdrawal data are documented quantities, obtained from questionnaires sent to water users by the ISWS, of water withdrawn for public supply, for commercial establishments, for industrial and mining activities, and for thermoelectricpower generation. Other withdrawal values are estimated quantities of water, determined by extrapolating from related known data for the categories of domestic, irrigation, and livestock use. Water withdrawn in a county or hydrologic unit (drainage basin) may or may not be used in the same county or hydrologic unit; when water-withdrawal values are estimated, it is assumed that the water was withdrawn in the same county or hydrologic unit as its use, which may or may not be the case, however.

Data bases of water-use information are maintained by the ISWS and the U.S. Geological Survey (USGS). The data base maintained by the USGS includes water-withdrawal data collected and aggregated by the ISWS, water-returns data collected by the Illinois Environmental Protection Agency, and wateruse data estimated by the USGS. This USGS data base contains a site-specific water-use data system (SSWUDS) and an aggregated water-use data system (AWUDS).

\footnotetext{
${ }^{1}$ Italicized terms are defined in the Glossary.
}

\section{Purpose and Scope}

The purpose of this report is to present aggregated data on water withdrawals during 1990 in Illinois. Water-withdrawal data were collected from public-supply facilities, mining companies, thermoelectric-power generating plants, and self-supplied commercial and industrial establishments. Withdrawals for self-supplied domestic, irrigation, and livestock purposes were estimated by means of methods discussed later in the report. The data for the entire State were aggregated by county (fig. 1) and hydrologic unit (fig. 2).

\section{Acknowledgments}

The author thanks Kenneth J. Hlinka, Kris K. Klindworth, and Kay M. Charles of the Illinois State Water Survey for the time and effort expended to collect and compile the water-withdrawal data for 1990.

\section{METHODOLOGY}

Water-withdrawal data are collected or estimated using various methods. Data provided by the water users generally are more accurate than estimates because they are measured values, in most cases.

\section{Collection of Water-Withdrawal Data}

Water-withdrawal data (primarily site-specific metered usage) for public-supply facilities, mining companies, thermoelectric-power generating plants, and self-supplied commercial and industrial establishments are obtained every year from questionnaires sent to about 4,000 water users by the ISWS. The water users are asked to return the forms to the ISWS where the data are checked and digitized. If a water user does not respond to the questionnaire, a second questionnaire is sent, and a follow-up telephone call is made as a final recourse. If it is determined that a water user cannot provide the data, an amount is estimated based on other information provided by the water user or by extrapolating data from previous years. If no previous data are available to make an estimate, no withdrawal data for that water user are entered into the data base. These data are aggregated by county and hydrologic unit by the ISWS and released to the USGS. 


\section{Water-Withdrawals Estimation Techniques}

Water use for self-supplied domestic, irrigation, and livestock purposes is estimated from other related data available by county aggregation, such as population and agricultural census figures. The estimated withdrawal data are subsequently aggregated by hydrologic unit by multiplying the proportion of each hydrologic unit within a county by the water-use estimate for the county. It is assumed that all unmetered selfsupplied water use for domestic purposes, irrigation, and livestock in Illinois is obtained from ground-water sources, except for a small amount of surface water used for irrigation. The estimated withdrawal data are entered directly into AWUDS. Deliveries from public supplies were estimated for domestic, commercial, industrial, and thermoelectric-power generation uses.

\section{Self-Supplied Domestic Withdrawals}

Self-supplied domestic water use is estimated by multiplying an estimated rural domestic per capita water use for each county by the self-supplied population for each county. The estimated rural domestic per capita water use in each county is the average per capita water use of the small water-supply systems that serve 800 people or less and have two or less commercial establishments (Kirk, 1987, p. 7). The self-supplied population is the difference between the total county population and the population served by public watersupply facilities in the county. The statewide average rural domestic per capita water use during 1990 was calculated at $95 \mathrm{gal} / \mathrm{d}$.

\section{Irrigation Withdrawals}

Irrigation water withdrawals are estimated by multiplying the irrigated crop acreage by the cumulative moisture surplus or deficit for plant transpiration determined from rainfall amounts (Kirk, 1987). The irrigated crop acreage in each county was obtained from Bowman and Kimpel (1991). Counties with a large number of golf courses have had the acreage of the golf courses included as irrigated acreage. Daily rainfall totals at weather stations for nearly all the counties were obtained from the monthly reports of the National Oceanic and Atmospheric Administration (1991a, 1991b, 1991c, 1991d). The rainfall between May 1 and August 31, 1990, was totaled on a 7-day basis and the seasonal cumulative moisture surplus or deficit was determined for each county by the following procedure.
1. If more than $1.25 \mathrm{in}$. of rain falls during the first 7 days of the growing season, one-half the amount of rain exceeding $1.25 \mathrm{in}$. is assumed to contribute to moisture surplus and is added to the cumulative moisture determination. If less than $1.25 \mathrm{in}$. of rain falls during that period, the difference between the actual rainfall and 1.25 in. is estimated to be the quantity of water, in inches, applied by irrigation during that period. This difference is subtracted from the cumulative moisture determination.

2. For each subsequent 7-day period during the growing season, the rainfall is totaled. One-half of the rainfall during the period in excess of $1.25 \mathrm{in}$. is added to the cumulative moisture determination. If the rainfall amount is less than 1.25 in., then the difference is subtracted from the cumulative moisture determination. The seasonal cumulative moisture surplus or deficit is determined for the entire crop-growing season. If the seasonal moisture is in deficit, this value is the total estimated irrigation water applied, in inches, for the year.

The rainfall and cumulative moisture surplus or deficit for plant transpiration were determined for each county for the 1990 crop-growing season. The total irrigation water use in each county was calculated by multiplying the cumulative moisture deficit, in inches, by the irrigated acreage for the county. The total irrigation water use was divided by 365 days to obtain a daily rate for the year.

\section{Livestock Withdrawals}

Water use for livestock purposes is determined by multiplying the county population of each major type of farm animal by the estimated water directly consumed by the animal and other water used in association with the animal (Kirk, 1987). The major animal populations for each county were obtained from the U.S. Bureau of Census (1989). The estimated water used from direct consumption by and uses associated with each animal type are as follows:

\begin{tabular}{lc}
\hline \multicolumn{1}{c}{ Animal type } & $\begin{array}{c}\text { Estimated water use } \\
\text { (gallons per day) }\end{array}$ \\
\hline Dairy cows & 35.0 \\
Beef cattle & 12.0 \\
Horses and mules & 12.0 \\
Hogs & 4.0 \\
Goats & 3.0 \\
Sheep & 2.0 \\
Turkeys & .12 \\
Chickens & .06 \\
Rabbits & .05 \\
Mink & .03 \\
\end{tabular}




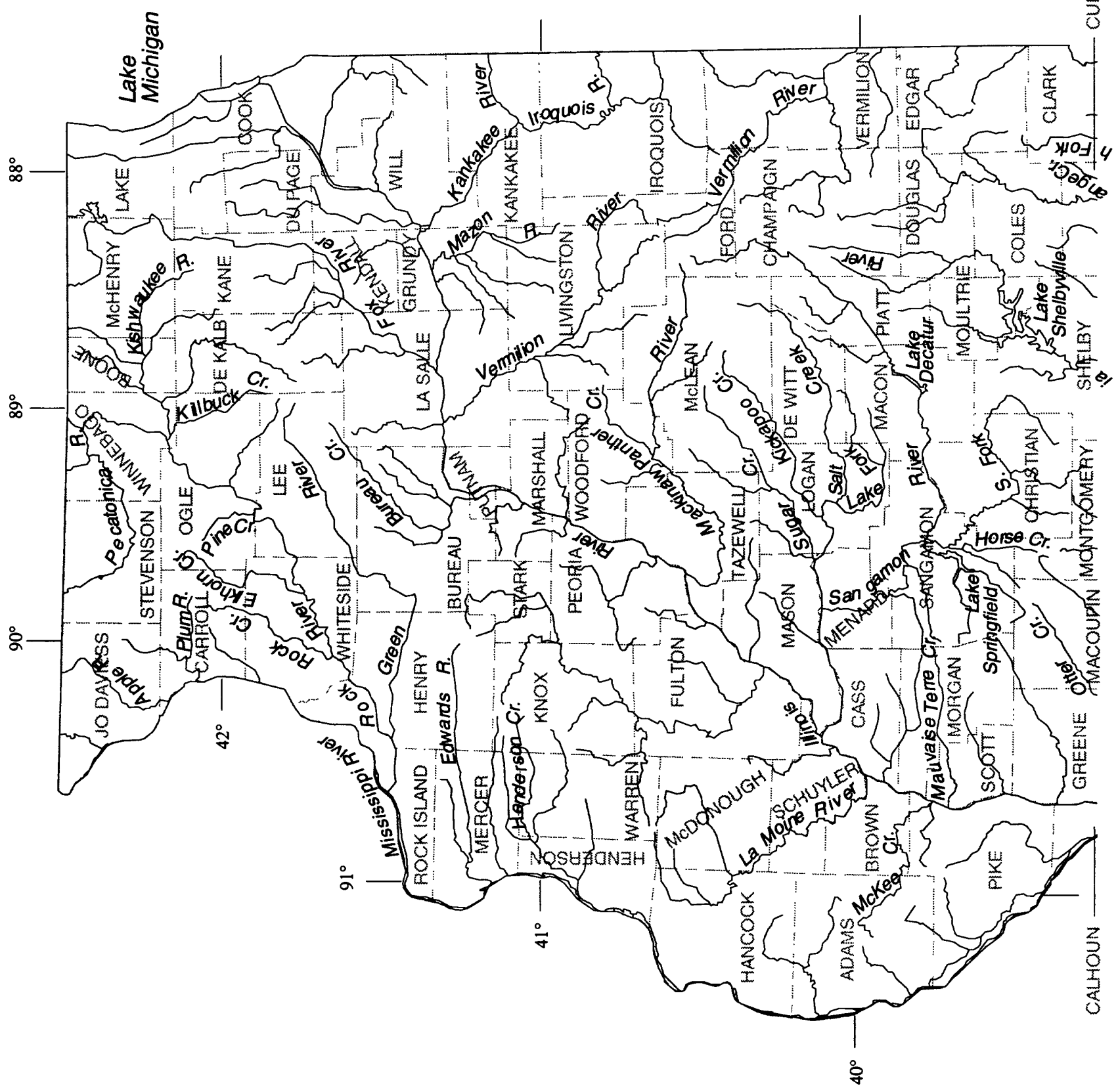




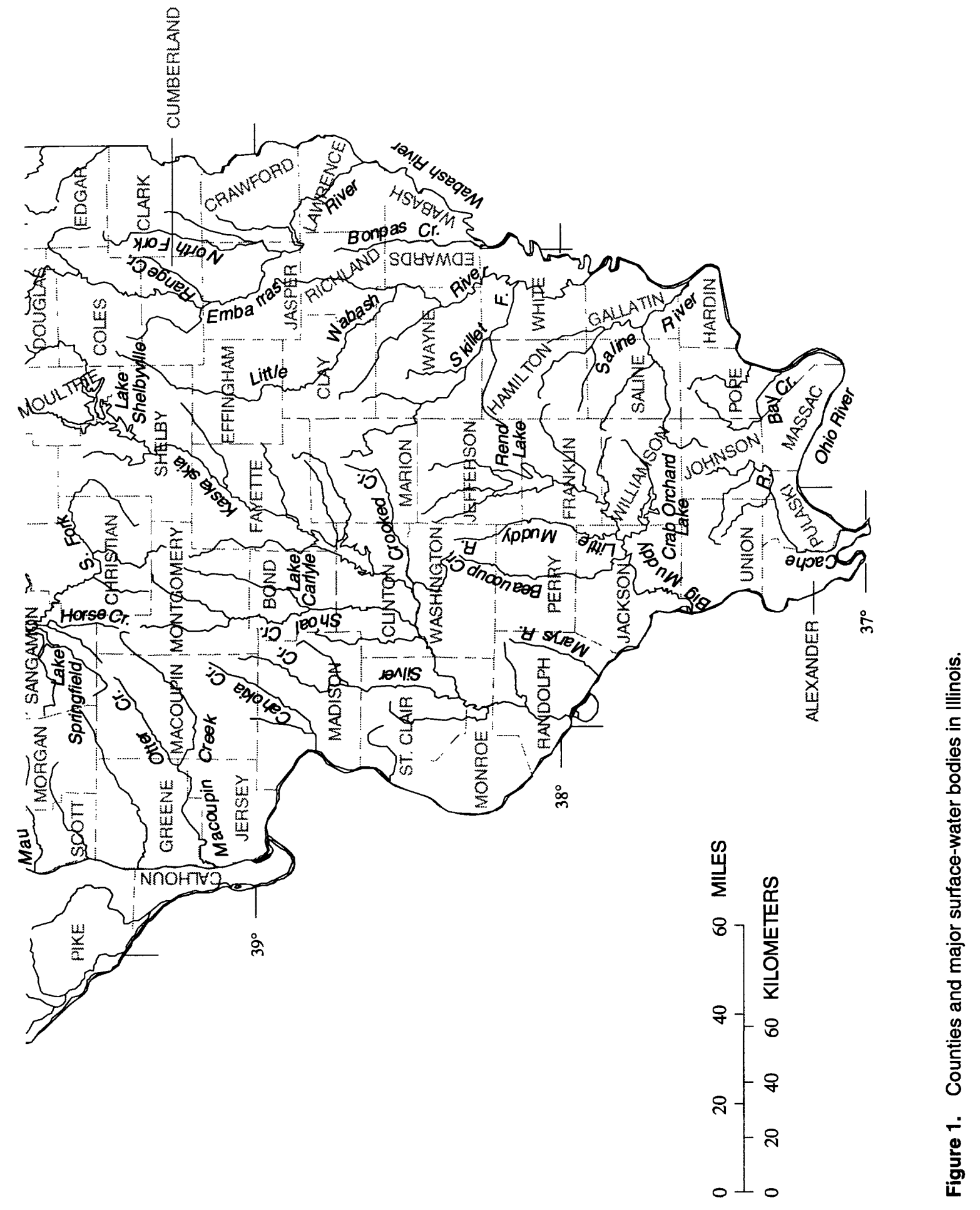



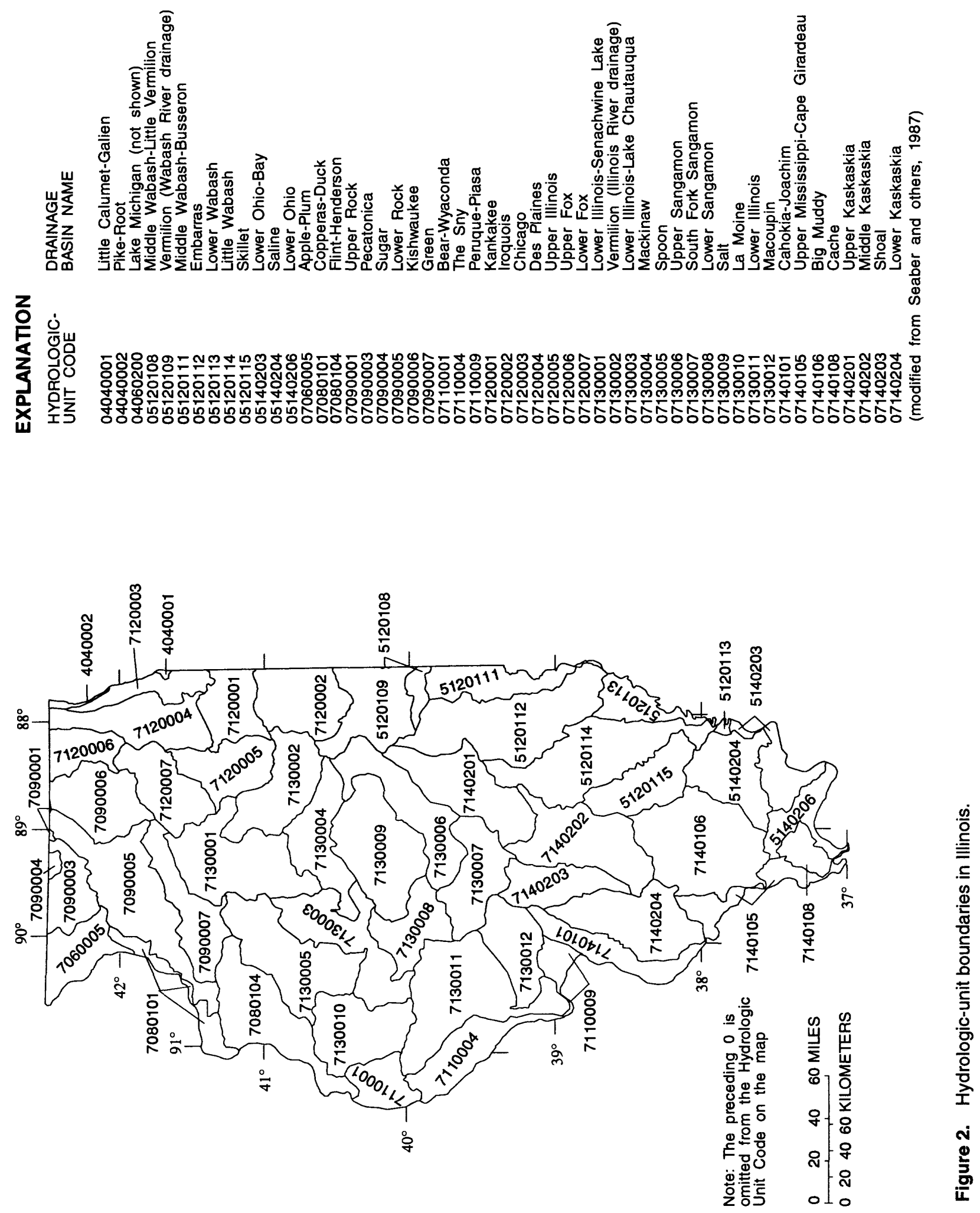


\section{ESTIMATED WATER WITHDRAWALS AND USE IN ILLINOIS, 1990}

Only offstream uses of water in Illinois are presented in this report; instream uses, such as for hydroelectric-power generation, are not considered. Data are aggregated by county and hydrologic unit. Surface-water and ground-water withdrawals are aggregated by major categories of water use.

\section{Public-Supply Withdrawals}

Water withdrawn and delivered from publicsupply facilities in Illinois during 1990 totaled about 1,859 Mgal/d (tables 1 and 2; all tables at end of report); about 1,956 Mgal/d was withdrawn in 1988 (Avery, 1995). Surface water and ground water were the sources for about 1,415 and $444 \mathrm{Mgal} / \mathrm{d}$, respectively, of the withdrawals for public supply during 1990; about 1,495 and $462 \mathrm{Mgal} / \mathrm{d}$ of surface water and ground water, respectively, were withdrawn in 1988 (Avery, 1995).

Withdrawals from ground water and surface water for public supply are subsequently delivered to water users connected to the water-distribution system. Water from public-supply facilities is delivered to households for domestic purposes, commercial establishments, industrial concerns, and thermoelectricpower plants. Eighty-nine, seventy-four, and thirty-six percent of the water used for domestic, commercial, and industrial purposes, respectively, were delivered by public-supply facilities. A minimal amount (less than $2 \mathrm{Mgal} / \mathrm{d}$ ) of water was delivered by publicsupply facilities to thermoelectric-power generators.

Eighty-eight percent of the population of Illinois are served by public-supply facilities. The largest withdrawals of ground water for public supply were in Champaign, Cook, Du Page, Kane, Lake, La Salle, McHenry, Madison, Peoria, Tazewell, Will, and Winnebago Counties (fig. 3). The largest amounts of surface water withdrawn for public supply were from Lake Michigan, the Mississippi River, and the Sangamon River. About 1,146 Mgal/d, or 81 percent of the surface water withdrawn and used in Illinois for public supply, is obtained from Lake Michigan (hydrologic unit 04060200) (table 2). Counties with large withdrawals from surface-water sources for public supply were Cook, Lake, Macon, Madison, and Sangamon (fig. 4).

\section{Estimated Self-Supplied Domestic Withdrawals}

Self-supplied water for domestic use includes the relatively small amounts of water used by individual households. All self-supplied domestic water in Illinois is reported to be ground water obtained from a water well or spring (Kirk, 1987). About $115 \mathrm{Mgal} / \mathrm{d}$ is estimated to have been withdrawn for self-supplied domestic purposes in 1990 (tables 1 and 2); about $122 \mathrm{Mgal} / \mathrm{d}$ was estimated to have been used in 1988 (Avery, 1995).

About 11 percent of the total water used for domestic use in Illinois was self supplied. The largest withdrawals of self-supplied domestic water were in Du Page, Lake, McHenry, Will, and Winnebago Counties (fig. 5). The population served by public-supply facilities and the self-supplied population in Illinois are shown in tables 3 and 4 . The greatest proportion of selfsupplied to public-supplied population is in Calhoun, Cumberland, Edwards, Henderson, Jasper, Kendall, and Shelby Counties.

\section{Commercial Withdrawals}

Total self-supplied withdrawals and deliveries from public-water facilities for commercial use were about $672 \mathrm{Mgal} / \mathrm{d}$ (tables 5 and 6). About $173 \mathrm{Mgal} / \mathrm{d}$ was self supplied by the commercial establishments. More surface water than ground water was withdrawn for self-supplied commercial use. The largest selfsupplied commercial withdrawals of ground water were in Champaign, Cook, Du Page, Jackson, Madison, Mason, Massac, and St. Clair Counties (fig. 6). The largest self-supplied commercial withdrawals of surface water were in Calhoun, Carroll, Cook, Jersey, and Williamson Counties (fig. 7).

\section{Estimated Irrigation Withdrawals}

Total irrigation withdrawals were estimated to have been about $78 \mathrm{Mgal} / \mathrm{d}$ in 1990 (tables 7 and 8); about $302 \mathrm{Mgal} / \mathrm{d}$ was withdrawn in 1988 (Avery, 1995). Irrigated acreage has increased from 281,370 in 1988 (Avery, 1995) to 286,540 acres in 1990.

Irrigation water is applied during the growing season of May-August, but the total water used is averaged over the entire year (as presented in this report). The source of most irrigation water is ground water, 


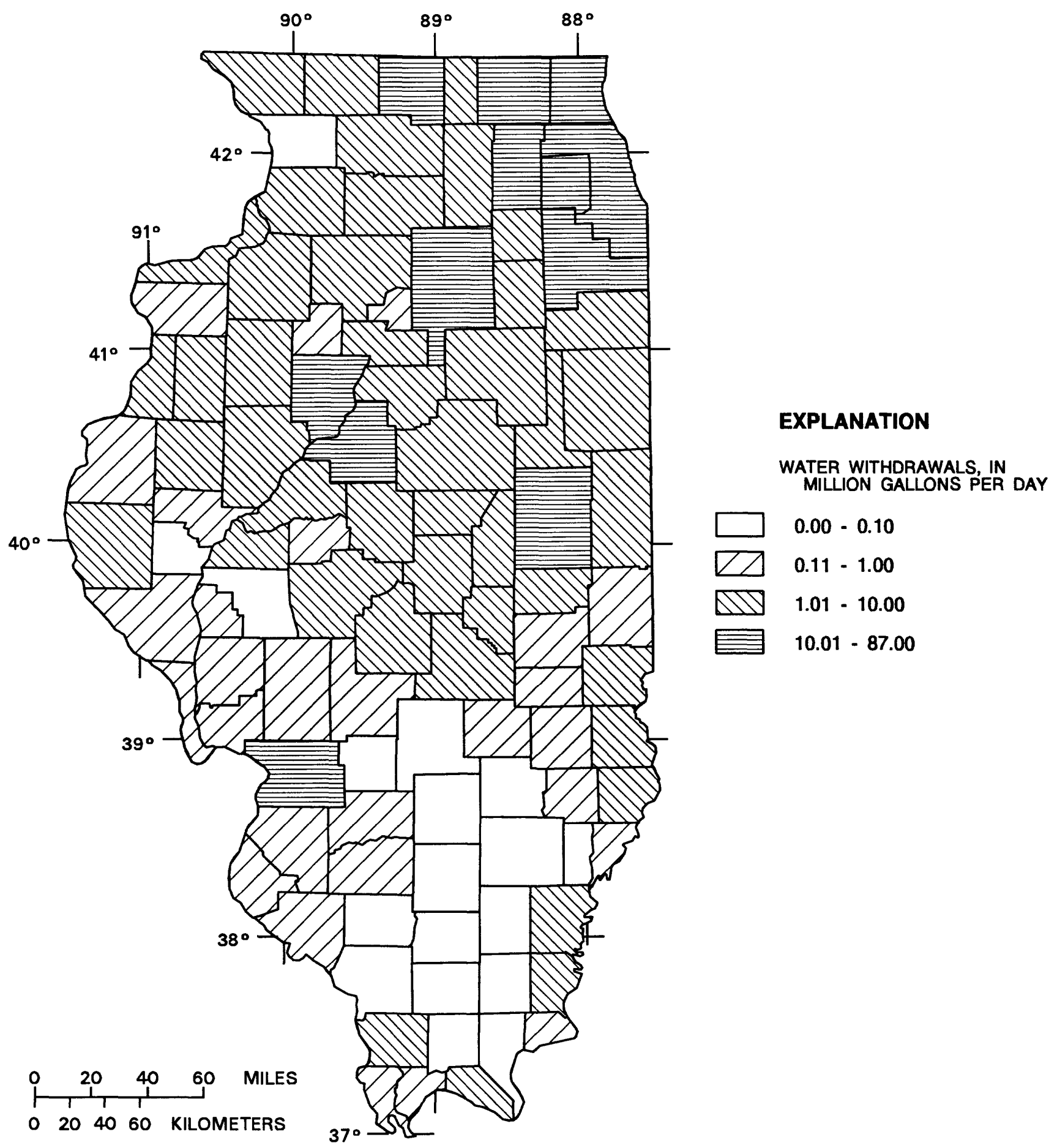

Figure 3. Public-supply withdrawals of ground water in Illinois, by county, 1990 . 


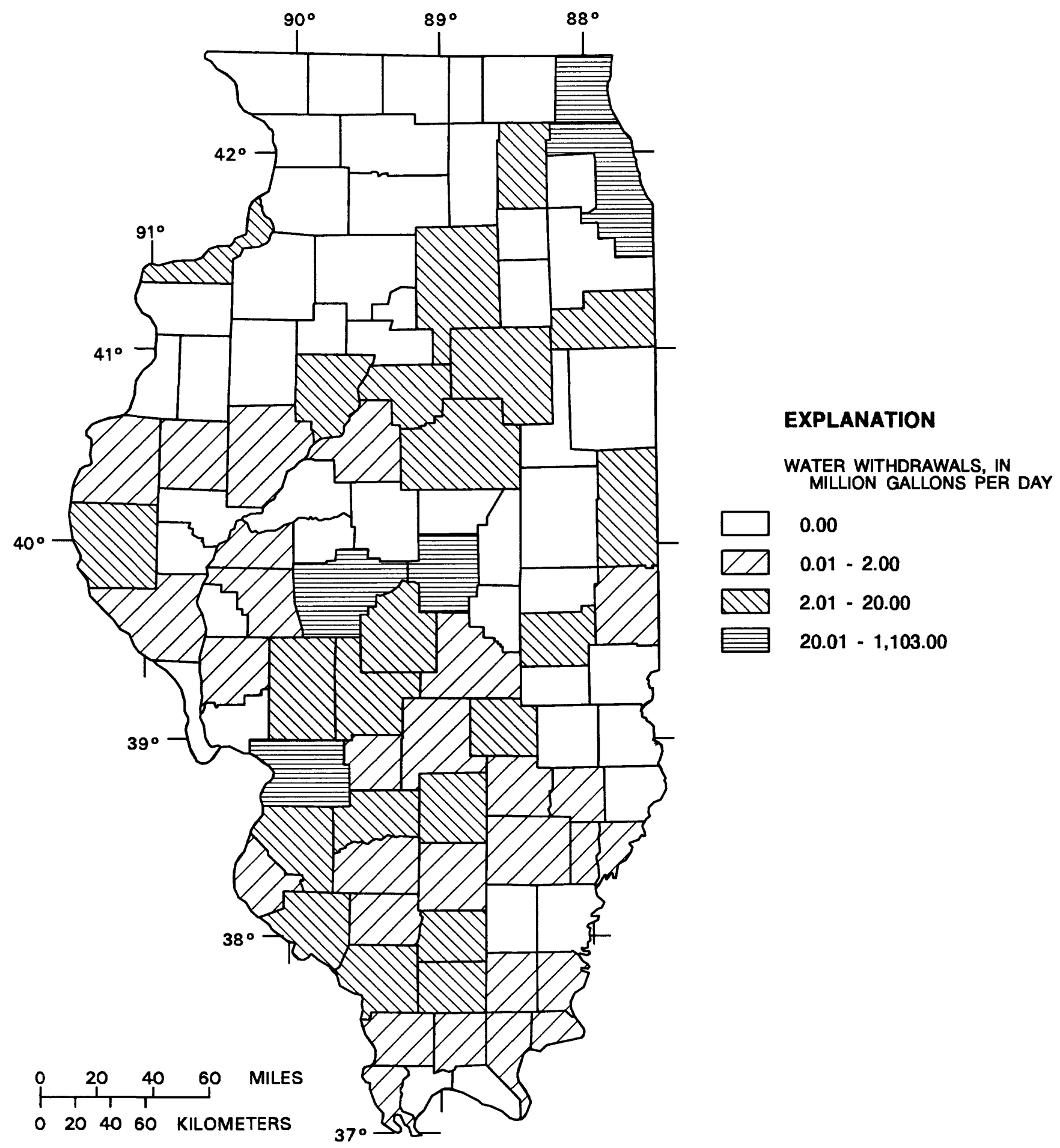

Figure 4. Public-supply withdrawals of surface water in Illinois, by county, 1990. 


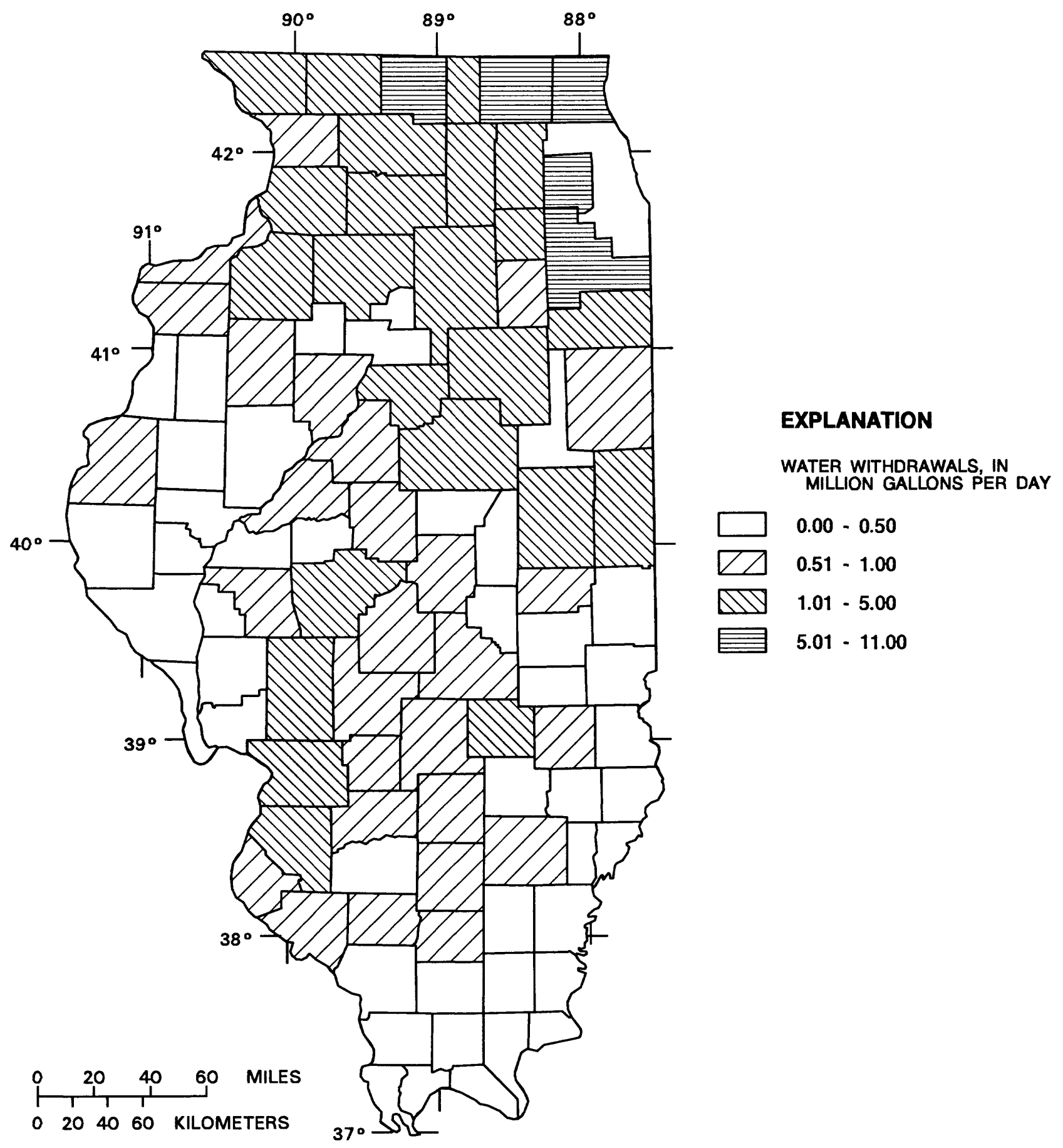

Figure 5. Estimated self-supplied domestic withdrawals of water in Illinois, by county, 1990. 


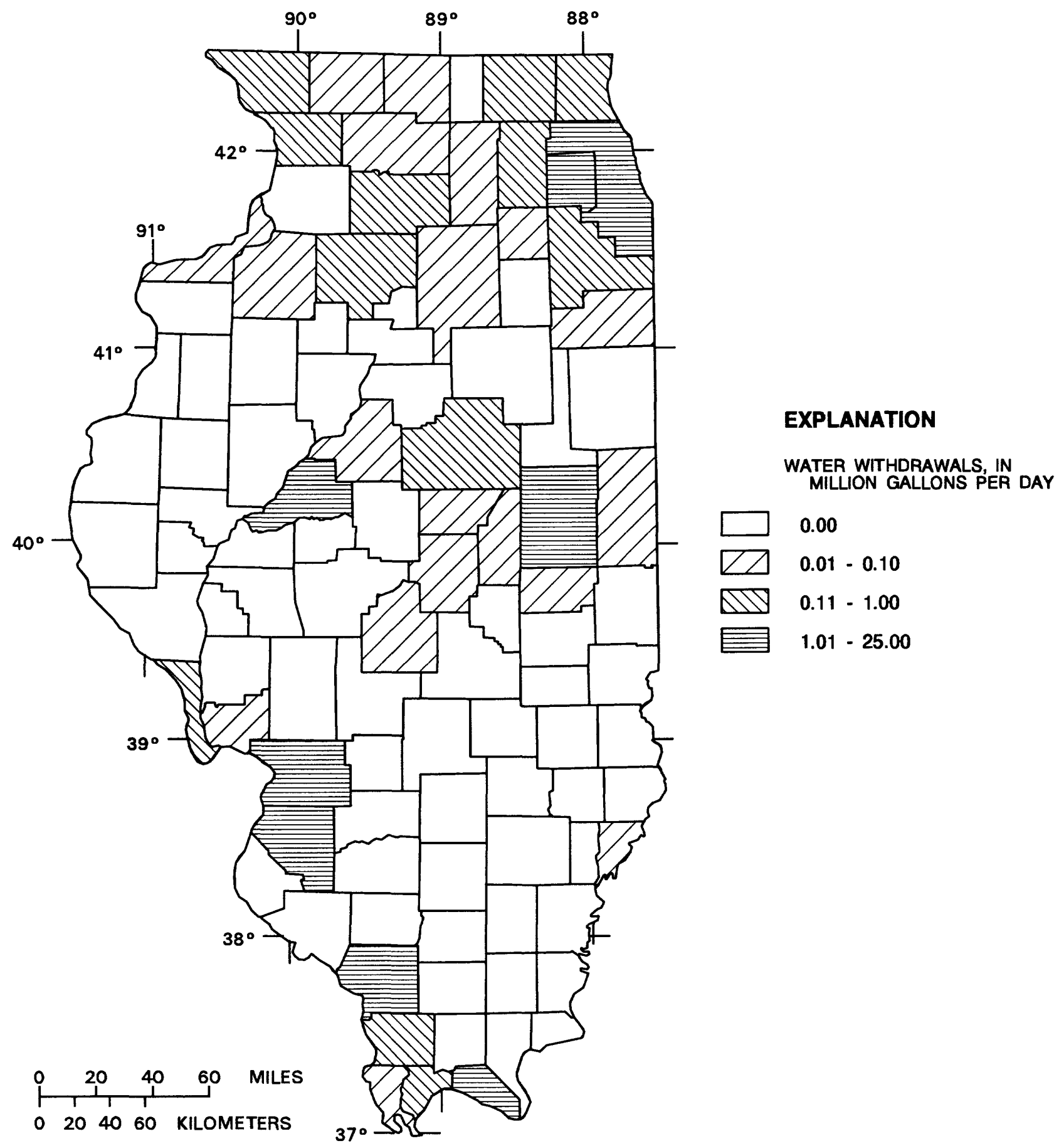

Figure 6. Self-supplied commercial withdrawals of ground water in Illinois, by county, 1990 . 


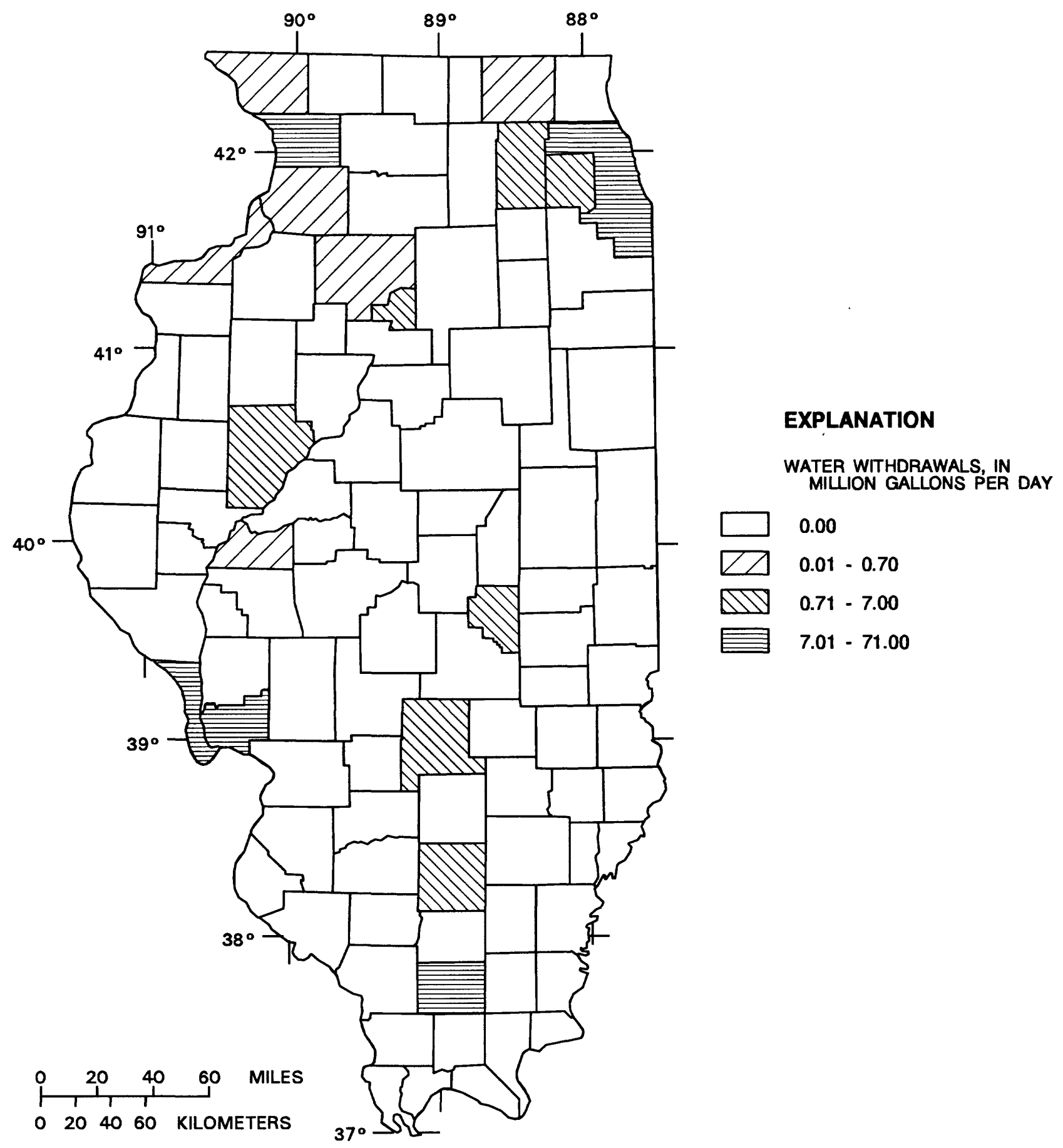

Figure 7. Self-supplied commercial withdrawals of surface water in Illinois, by county, 1990. 
except for relatively small amounts (less than $1 \mathrm{Mgal} / \mathrm{d}$ ) of surface water applied in numerous counties throughout the State. All ground water used for irrigation is applied by spray methods; thus, very little conveyance loss results during the process of irrigation. Most of the irrigation water was used in Clark, Cook, Du Page, Gallatin, Kankakee, Lawrence, Lee, Mason, Tazewell, White, and Whiteside Counties (fig. 8).

\section{Estimated Livestock Withdrawals}

Total withdrawals for livestock and animal specialties use were about $63 \mathrm{Mgal} / \mathrm{d}$ in 1990 (tables 7 and 8); about $56 \mathrm{Mgal} / \mathrm{d}$ was used for livestock in 1988 (Avery, 1995). It is assumed that the source of water for livestock uses is ground water, either wells or springs. About $9 \mathrm{Mgal} / \mathrm{d}$ of ground water and about $2 \mathrm{Mgal} / \mathrm{d}$ of surface water were used for animal specialties. The largest use for livestock and animal specialties was in Henry, Jo Daviess, Mason, and Stephenson Counties (fig. 9).

\section{Industrial Withdrawals}

Self-supplied withdrawals and deliveries from public supply for industrial use were about $728 \mathrm{Mgal} / \mathrm{d}$ in 1990 (tables 9 and 10); about $743 \mathrm{Mgal} / \mathrm{d}$ was used in 1988 (Avery, 1995). The industries included in this category are the 20 major Division D Manufacturing groups from the Standard Industrial Classification Manual (Office of Management and Budget, 1987). About $464 \mathrm{Mgal} / \mathrm{d}$ was self-supplied withdrawals by industrial facilities; 33 percent of the self-supplied water was from ground-water sources. The largest selfsupplied withdrawals of ground water for industrial use were in Adams, Champaign, Cook, Grundy, La Salle, Madison, Massac, Morgan, Peoria, Rock Island, Tazewell, Whiteside, Will, and Winnebago Counties (fig. 10). The largest self-supplied withdrawals of surface water for industrial use were in Cook, Lake, Madison, Peoria, Rock Island, Tazewell, and Will Counties (fig. 11). No saline ground water or surface water is withdrawn for industrial use.

\section{Mining Withdrawals}

A total of about $94 \mathrm{Mgal} / \mathrm{d}$ was withdrawn during mining activities in 1990; about $94 \mathrm{Mgal} / \mathrm{d}$ was withdrawn in 1988 (Avery, 1995). Both fresh and saline ground water are withdrawn during mining (tables 11 and 12). Only fresh surface water occurs in Illinois; thus, the fresh surface water used during mining is all freshwater. About $61 \mathrm{Mgal} / \mathrm{d}$ of mining withdrawals was from surface-water sources. About $33 \mathrm{Mgal} / \mathrm{d}$ of mining withdrawals was from groundwater sources; about $25 \mathrm{Mgal} / \mathrm{d}$ of the ground water was saline. Most of the ground water withdrawn during mining was in the southern Illinois counties of Crawford, Fayette, Gallatin, Hardin, Jasper, Lawrence, Perry, Wabash, Wayne, and White (fig. 12). Most of the surface water withdrawn during mining was in Champaign, DeKalb, Franklin, La Salle, McHenry, Perry, St. Clair, Saline, and Williamson Counties (fig. 13). The total consumptive use of the water withdrawn during mining was about $46 \mathrm{Mgal} / \mathrm{d}$, or about 49 percent of the total water withdrawn during mining (tables 11 and 12).

\section{Thermoelectric-Power Generation Withdrawals}

Self-supplied withdrawals and deliveries from public supplies for thermoelectric-power generation were about $15,170 \mathrm{Mgal} / \mathrm{d}$ in 1990 (tables 13 and 14); about $15,589 \mathrm{Mgal} / \mathrm{d}$ was withdrawn in 1988 (Avery, 1995). Both fossil-fuel and nuclear-fuel thermoelectric-power generators are included in this category.

Most of the water withdrawn for thermoelectricpower generation is from surface-water sources and is withdrawn at or near the power-generating stations, although a small amount of water is obtained from self-supplied ground water and deliveries from publicwater facilities. Most of the ground water withdrawn for thermoelectric-power generation was in Rock Island, Tazewell, and Will Counties (fig. 14). Most of the surface water withdrawn for thermoelectric-power generation was in Grundy, Lake, Randolph, and Will Counties (fig. 15). Consumptive use of water for thermoelectric-power generation was about $370 \mathrm{Mgal} / \mathrm{d}$, or about 2 percent of the total water withdrawn for thermoelectric-power generation.

\section{Total Water Withdrawals}

The total amount of water withdrawn in Illinois during 1990 was about $18,016 \mathrm{Mgal} / \mathrm{d}$ (tables 15 and 16). This amount was about $740 \mathrm{Mgal} / \mathrm{d}$ less than in 


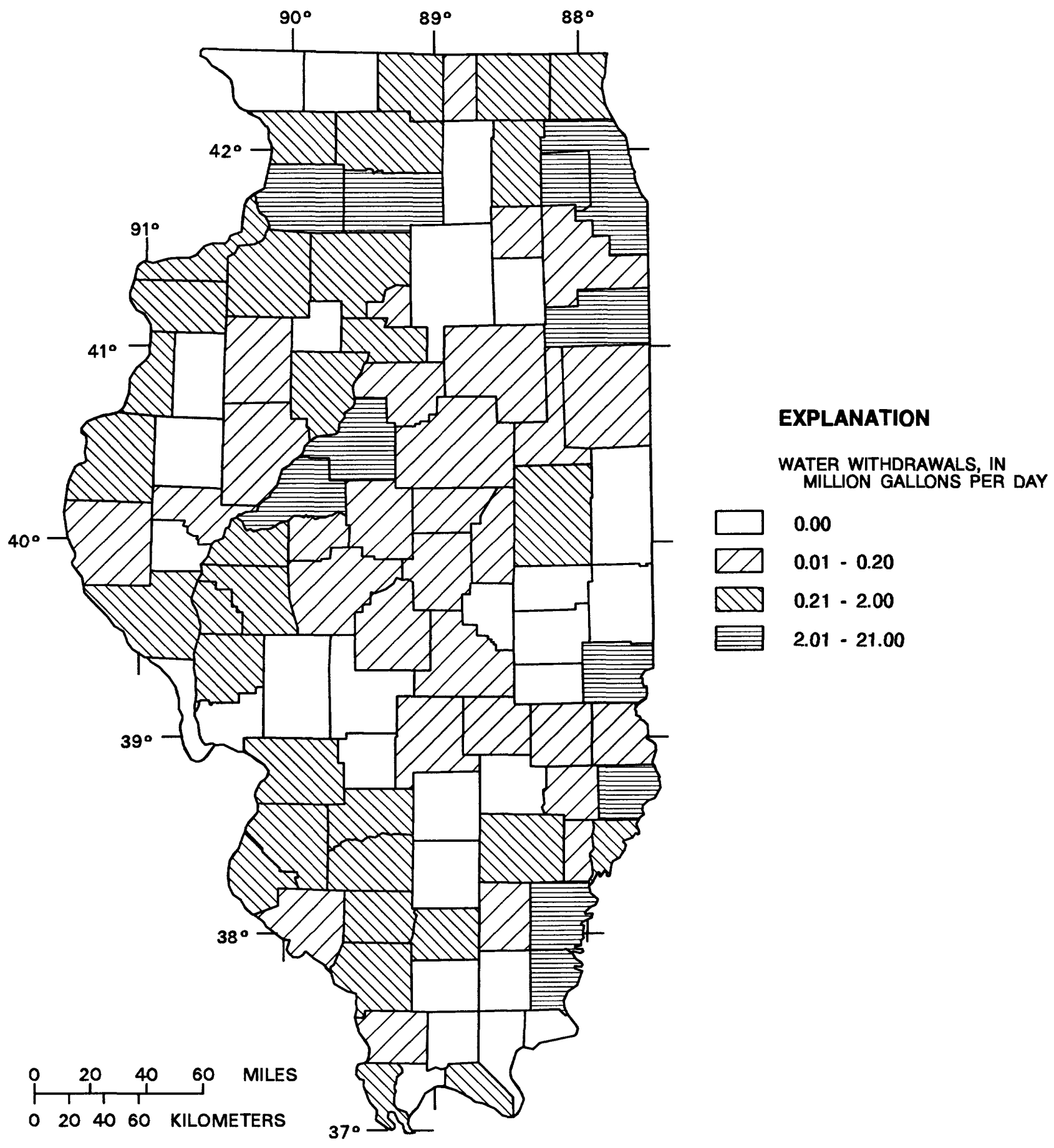

Figure 8. Estimated irrigation withdrawals of water in Illinois, by county, 1990. 


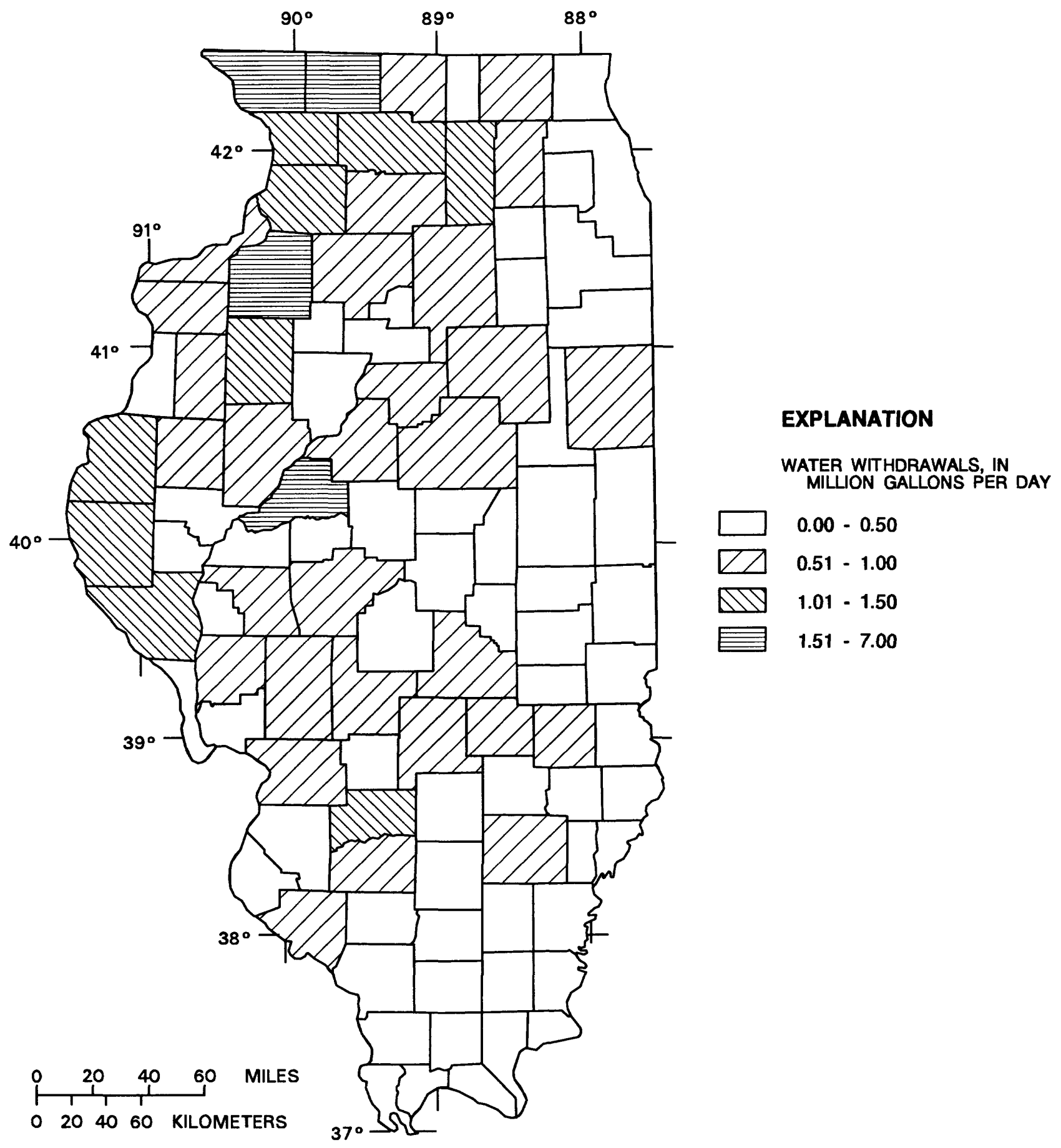

Figure 9. Estimated livestock and animal specialties withdrawals of water in Illinois, by county, 1990. 


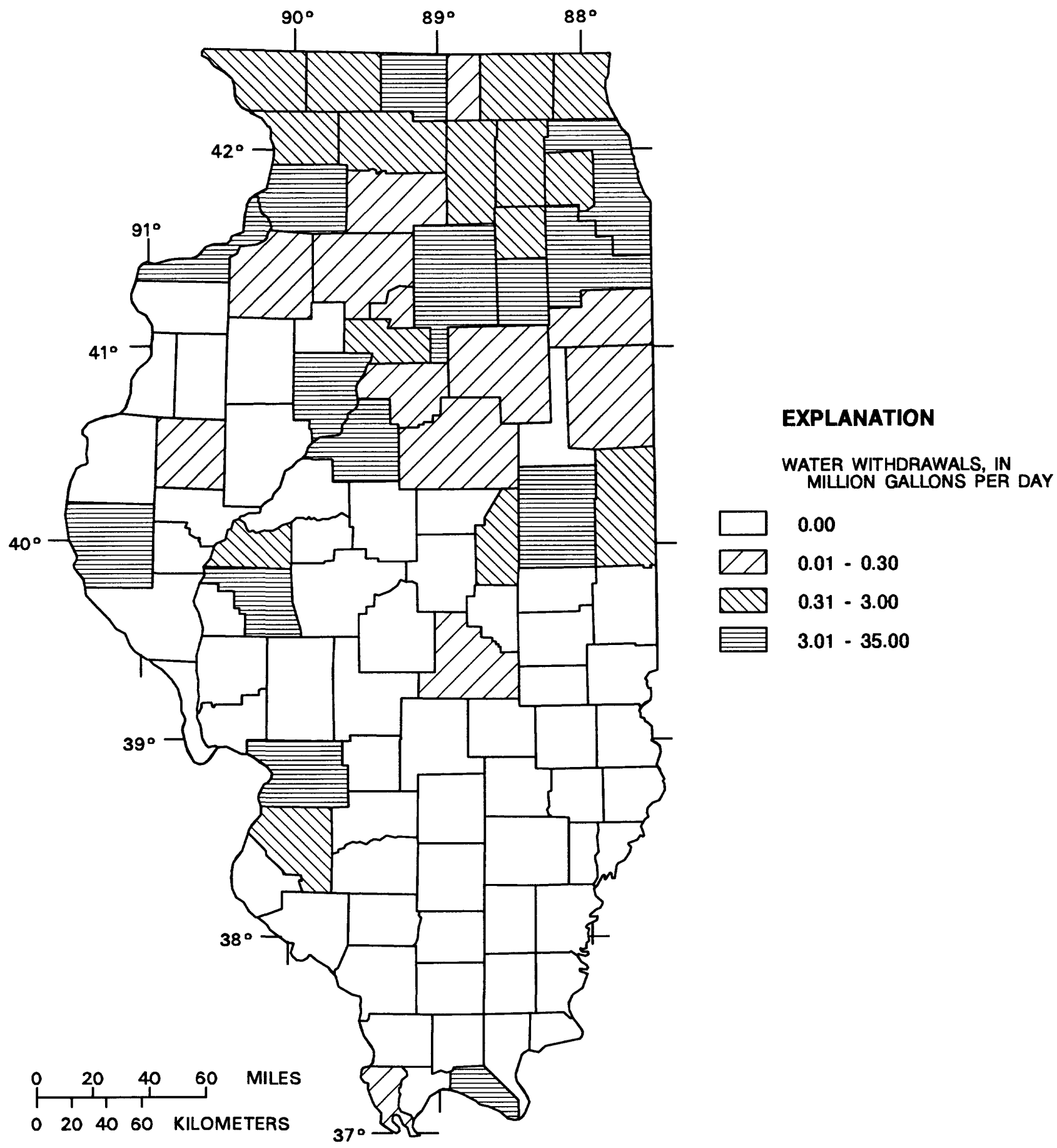

Figure 10. Self-supplied industrial withdrawals of ground water in Illinois, by county, 1990. 


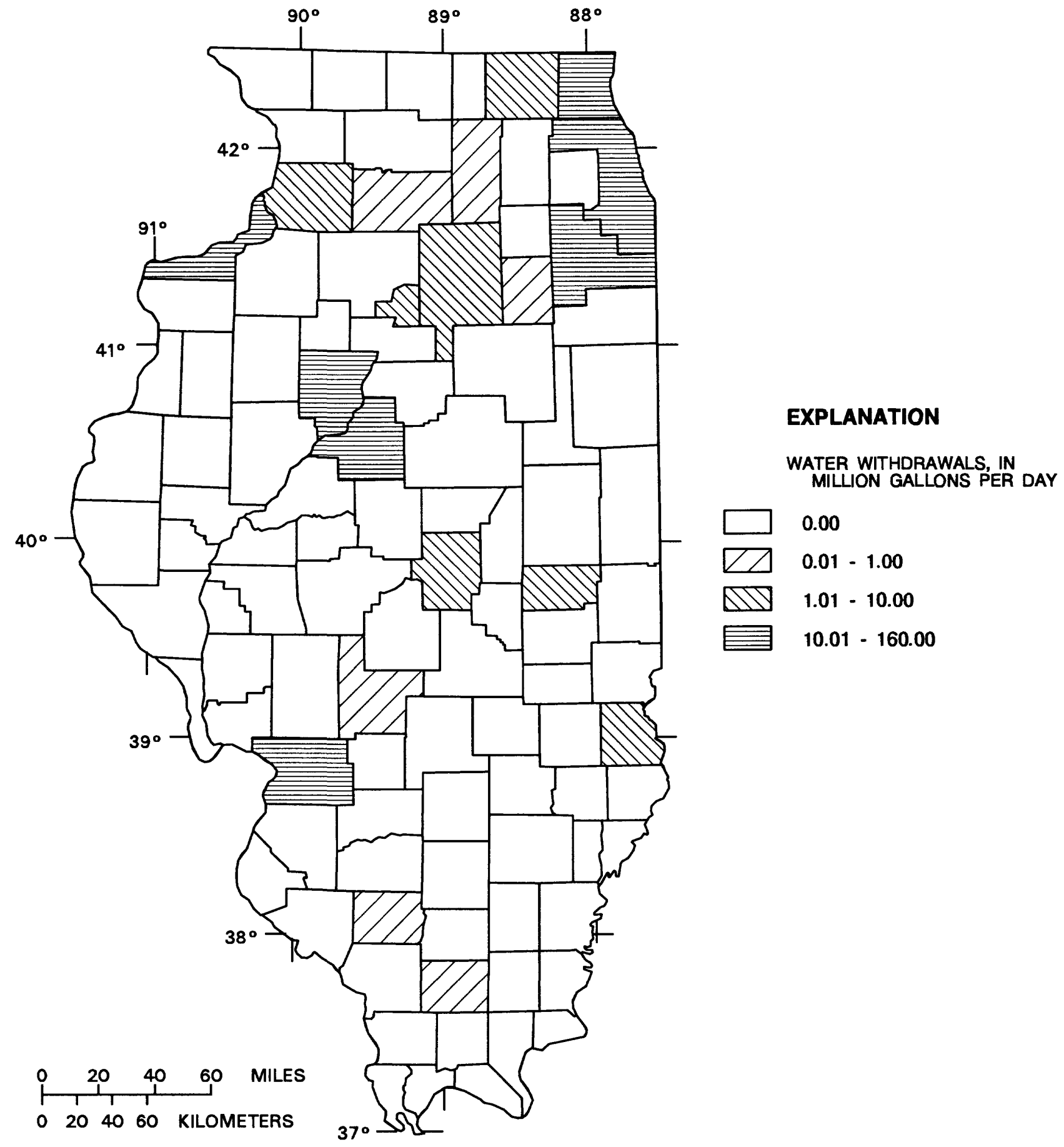

Figure 11. Self-supplied industrial withdrawals of surface water in Illinois, by county, 1990. 


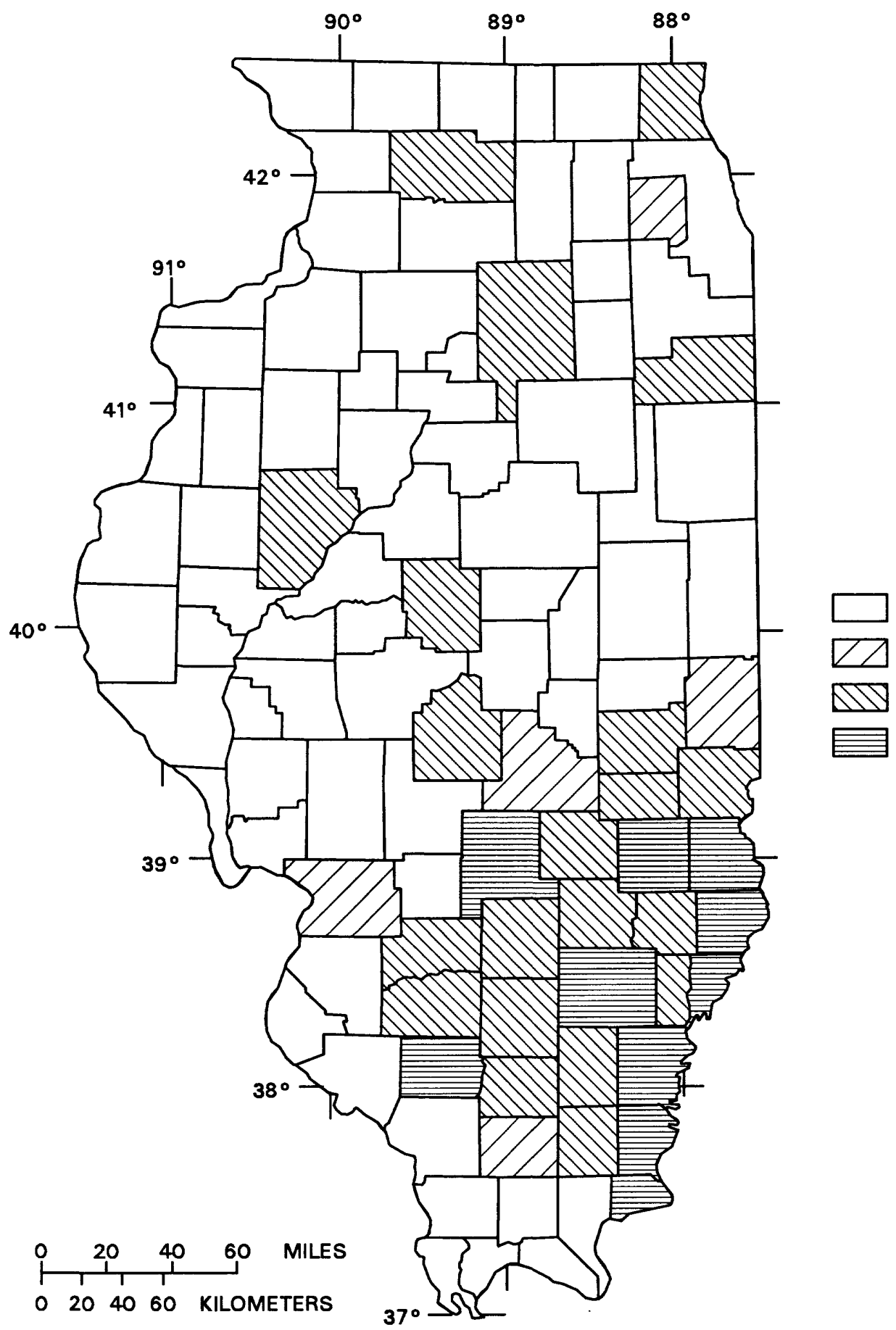

\section{EXPLANATION}

WATER WITHDRAWALS, IN MILLION GALLONS PER DAY

\subsection{0}

$0.01-0.10$

$0.11-1.00$

$1.01 \cdot 8.00$

Figure 12. Mining withdrawals of ground water in Illinois, by county, 1990 . 


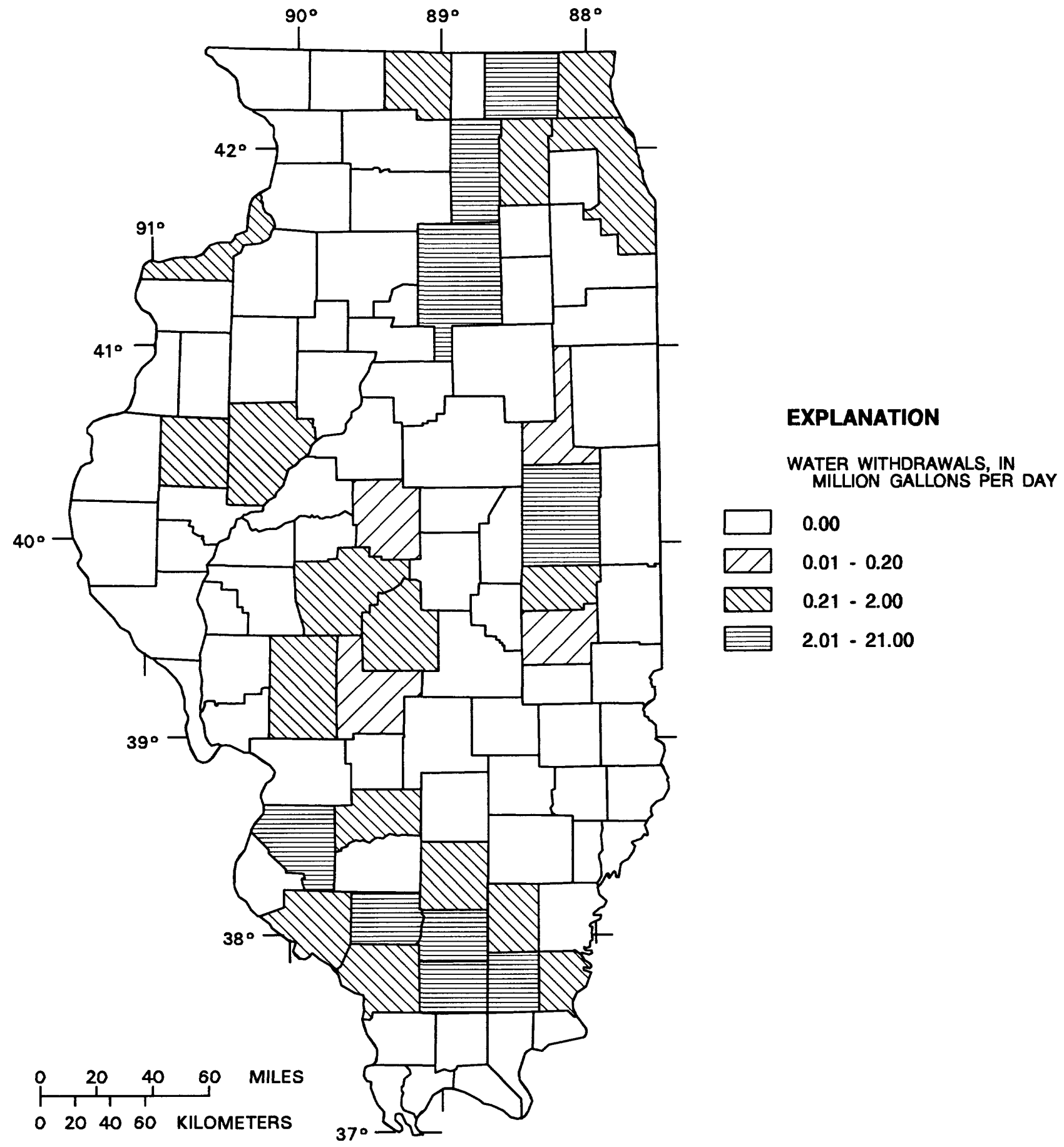

Figure 13. Mining withdrawals of surface water in Illinois, by county, 1990. 


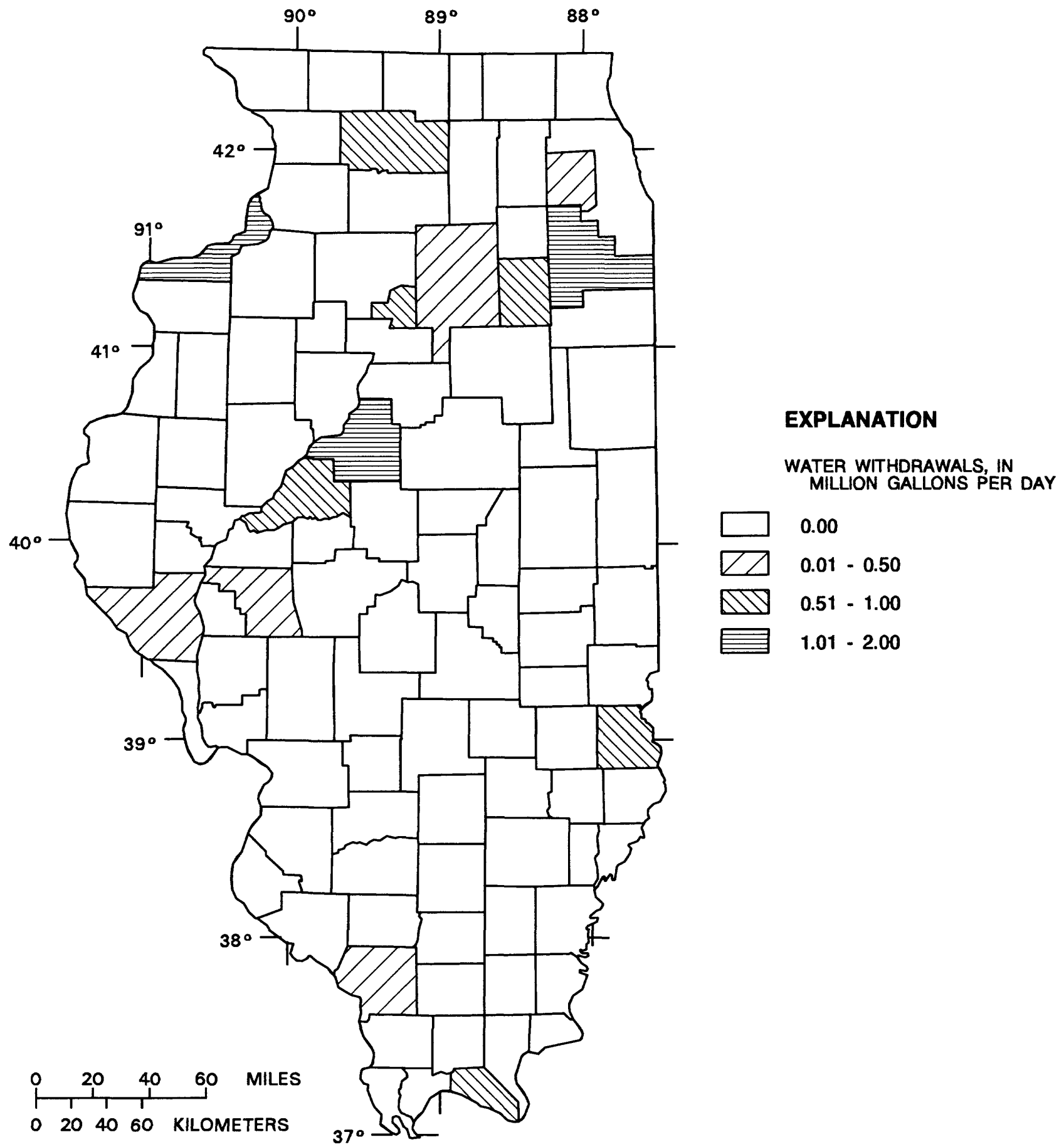

Figure 14. Self-supplied thermoelectric-power withdrawals of ground water in Illinois, by county, 1990 . 


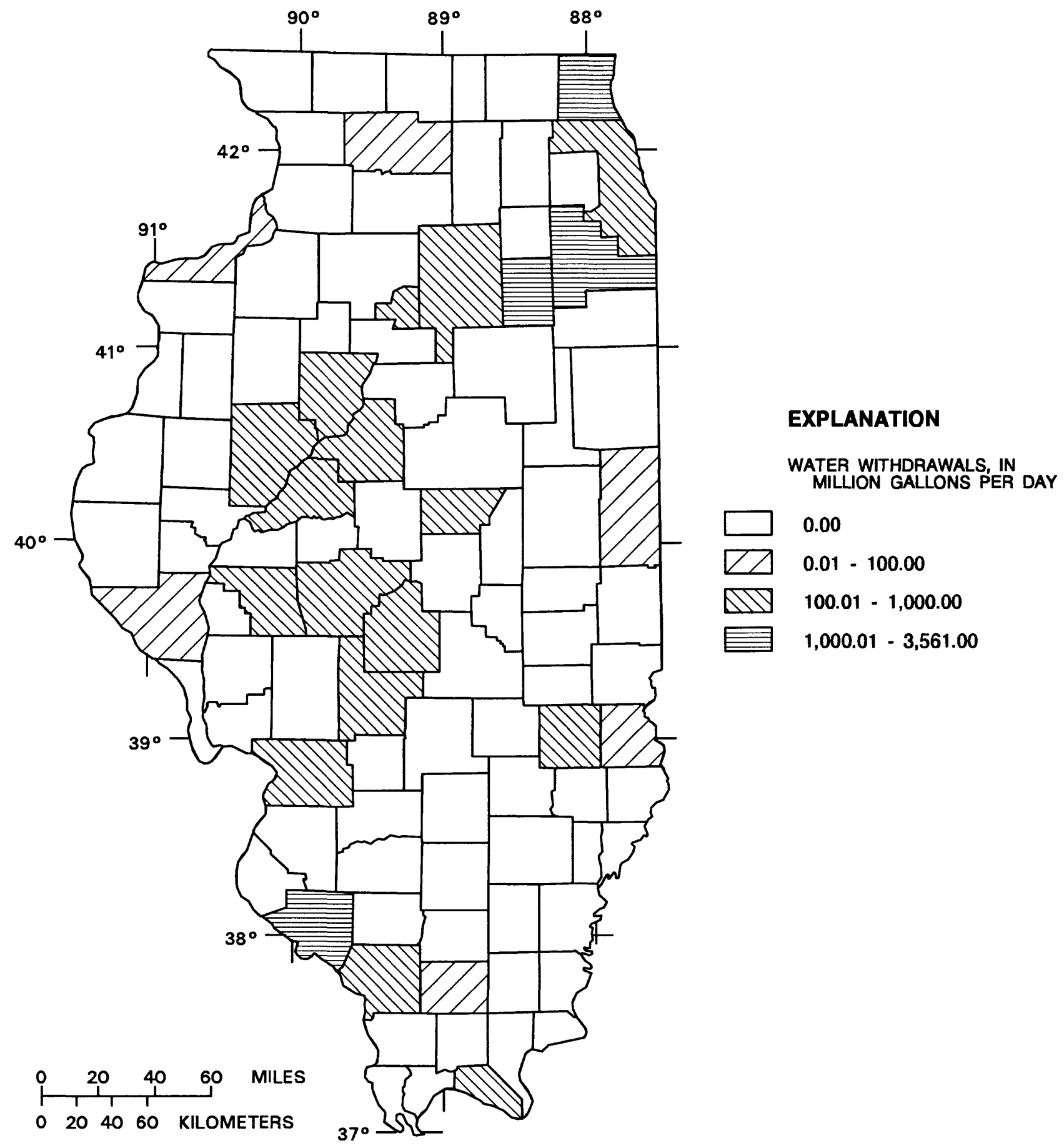

Figure 15. Self-supplied thermoelectric-power withdrawals of surface water in Illinois, by county, 1990. 
1988. The total withdrawal of fresh ground water, surface water, and saline ground water, excluding selfsupplied thermoelectric-power withdrawals, was about 2,847 Mgal/d. Self-supplied thermoelectric-power withdrawals are not considered in the data totals because the amount of water is so great relative to other water-use categories and the consumptive use is very low. About $936 \mathrm{Mgal} / \mathrm{d}$, or 33 percent, of the total water withdrawn in Illinois, excluding the self-supplied withdrawals for thermoelectric-power generation, was ground water; about $1,911 \mathrm{Mgal} / \mathrm{d}$ of surface water was withdrawn, excluding the large self-supplied withdrawals for thermoelectric-power generation. About $25 \mathrm{Mgal} / \mathrm{d}$ of the total ground water withdrawn and used in Illinois was saline.

Fifty-eight percent of the ground water withdrawn in 1990 was in Champaign, Cook, Du Page, Jackson, Kane, Lake, McHenry, Madison, Mason, Peoria, Tazewell, Will, and Winnebago Counties (fig. 16). Seventy-six percent of the surface water, excluding self-supplied thermoelectric-power withdrawals, was withdrawn in 1990 in Christian, Cook, Grundy, La Salle, Lake, Randolph, Tazewell, and Will Counties (fig. 17).

Surface-water, ground-water, and total water withdrawals by water-use category for Illinois during 1990 are shown in figure 18. Seventy-four percent of the total surface water, excluding withdrawals for thermoelectric-power generation, was withdrawn by public-supply facilities. The next largest use of surface water was self-supplied industrial withdrawals. Fortyseven percent of the total ground water was withdrawn by public-supply facilities. The next largest use of ground water was for irrigation. Sixty-five percent of the total water withdrawn in Illinois during 1990 was by public-supply facilities. The next largest uses of water in Illinois during 1990 were self-supplied industrial withdrawals and irrigation.

\section{SUMMARY}

Water withdrawn from public-supply facilities in Illinois during 1990 totaled about $1,859 \mathrm{Mgal} / \mathrm{d}$. Surface water and ground water were the sources for about 1,415 and $444 \mathrm{Mgal} / \mathrm{d}$, respectively, of the withdrawals for public supply in 1990 . The total water obtained from Lake Michigan for public supply was about $1,146 \mathrm{Mgal} / \mathrm{d}$. A total of about $115 \mathrm{Mgal} / \mathrm{d}$ was withdrawn for self-supplied domestic purposes. Total self-supplied withdrawals and deliveries from public- supply facilities for commercial use were about $672 \mathrm{Mgal} / \mathrm{d}$, of which about $173 \mathrm{Mgal} / \mathrm{d}$ was self supplied by the commercial establishments. Total irrigation water withdrawals were about $78 \mathrm{Mgal} / \mathrm{d}$. Total livestock and animal specialties withdrawals were about $63 \mathrm{Mgal} / \mathrm{d}$. Total self-supplied withdrawals and deliveries from public-supply facilities for industrial use were about $728 \mathrm{Mgal} / \mathrm{d}$. About $464 \mathrm{Mgal} / \mathrm{d}$ was self-supplied withdrawals by industrial facilities. A total of about $94 \mathrm{Mgal} / \mathrm{d}$ was withdrawn during mining activities. A total of about $33 \mathrm{Mgal} / \mathrm{d}$ of ground water was withdrawn during mining activities; about $25 \mathrm{Mgal} / \mathrm{d}$ of the ground water was saline. Total selfsupplied withdrawals and deliveries from publicsupply facilities for thermoelectric-power generation were about $15,170 \mathrm{Mgal} / \mathrm{d}$, about $370 \mathrm{Mgal} / \mathrm{d}$ was consumptively used.

The total amount of water withdrawn in Illinois during 1990 was about $18,016 \mathrm{Mgal} / \mathrm{d}$. This amount was about $740 \mathrm{Mgal} / \mathrm{d}$ less than in 1988 . The total water withdrawal, excluding self-supplied thermoelectric-power withdrawals, was about $2,847 \mathrm{Mgal} / \mathrm{d}$. About $936 \mathrm{Mgal} / \mathrm{d}$, or 33 percent, of the total water withdrawn in Illinois, excluding withdrawals for thermoelectric-power generation, was ground water; about $1,911 \mathrm{Mgal} / \mathrm{d}$ of surface water was withdrawn, excluding withdrawals for thermoelectric-power generation. About $25 \mathrm{Mgal} / \mathrm{d}$ of the total ground water withdrawn was saline. Seventy-four percent of the total surface water, excluding withdrawals for thermoelectric-power generation, was withdrawn by public-supply facilities. The next largest use of surface water was self-supplied industrial withdrawals. Forty-seven percent of the total ground water was withdrawn by public-supply facilities. The next largest use of ground water was for irrigation. Sixty-five percent of the total water withdrawn, excluding withdrawals for thermoelectricpower generation, in Illinois during 1990 was for public-supply facilities. The next largest uses of water in Illinois during 1990 were self-supplied industrial and irrigation withdrawals.

\section{REFERENCES CITED}

Avery, Charles, 1995, Estimated water withdrawals and use in Illinois, 1988: U.S. Geological Survey Open-File Report 95-309, 52 p. 


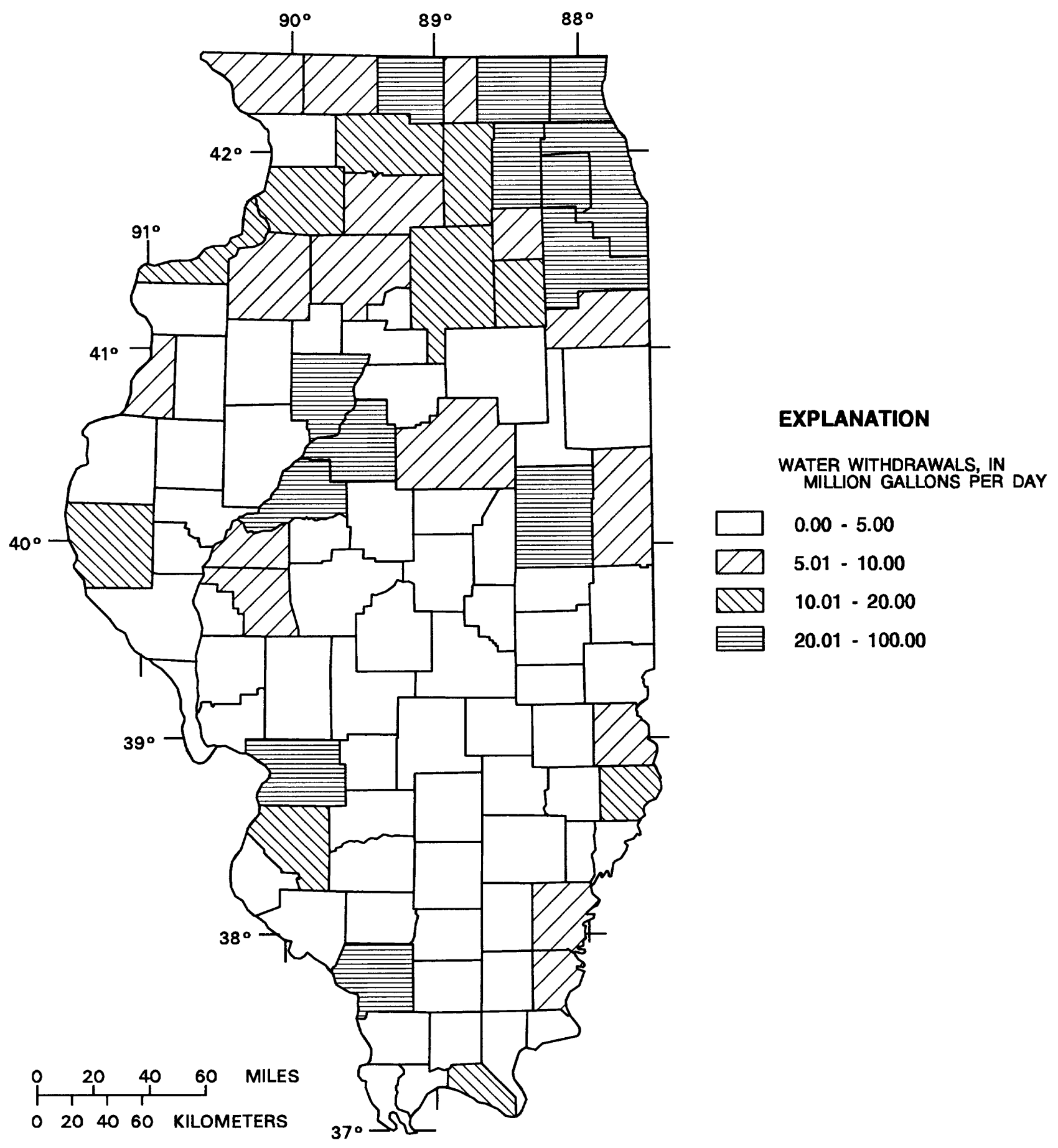

Figure 16. Total withdrawals of ground water in Illinois, by county, 1990. 


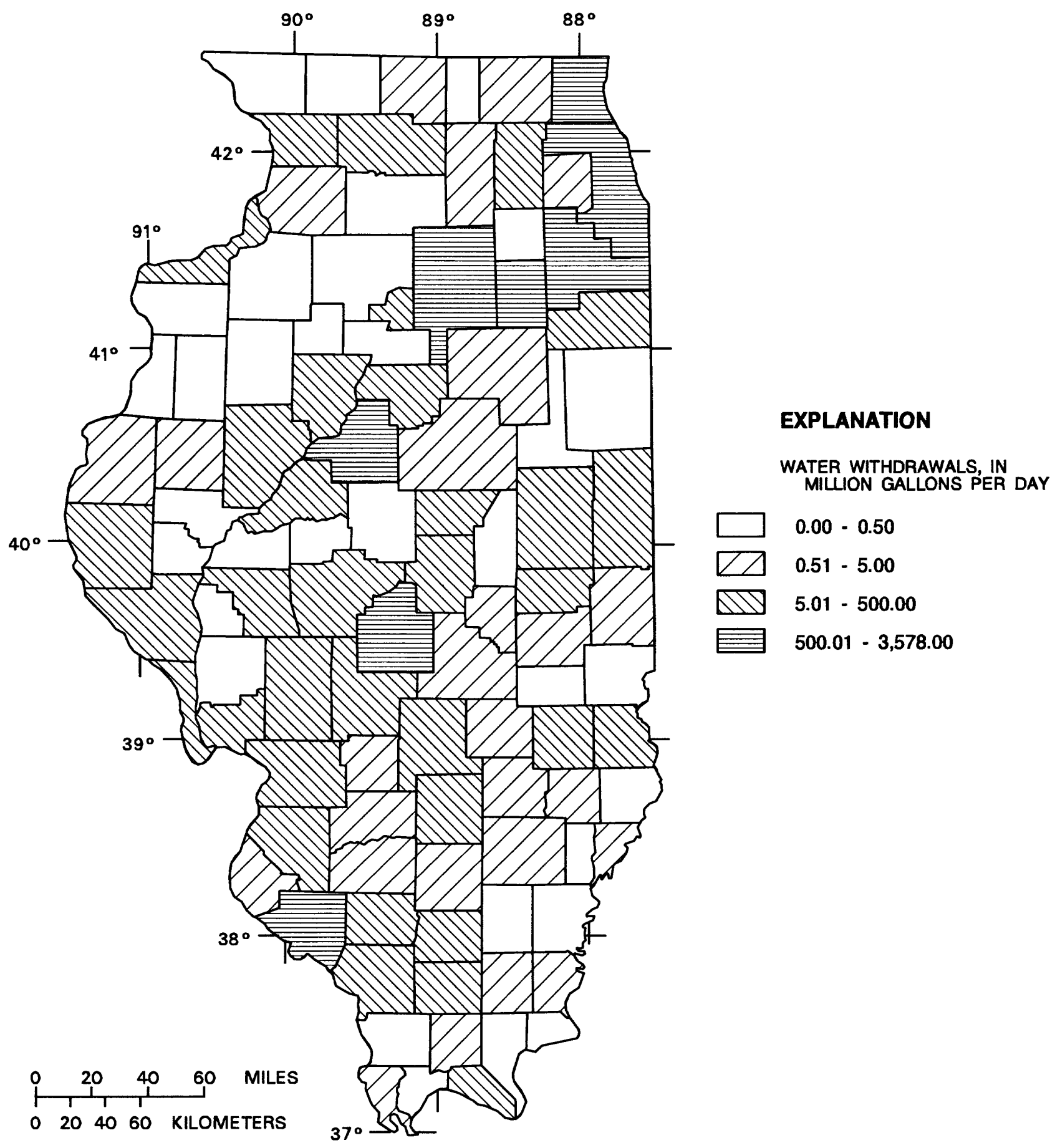

Figure 17. Total withdrawals of surface water in lllinois, by county, 1990. 


\section{SURFACE-WATER WITHDRAWALS}

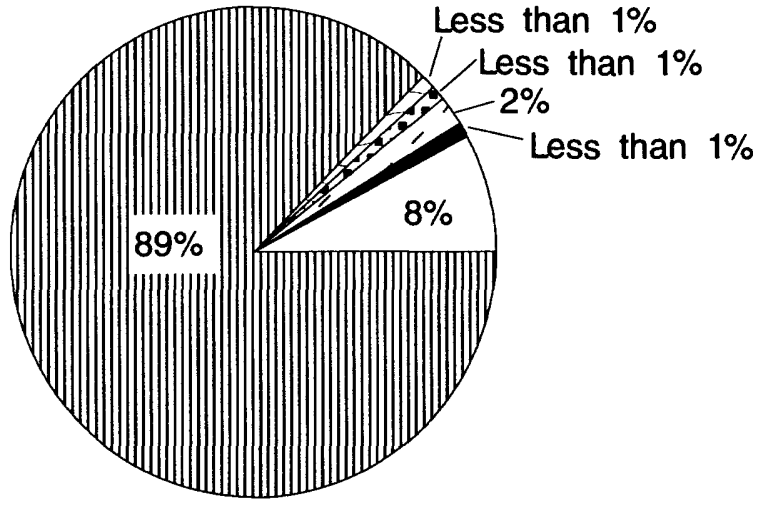

Total $=17,070.83$ million gallons per day

SURFACE-WATER WITHDRAWALS

(excluding self-supplied thermoelectricpower withdrawals)

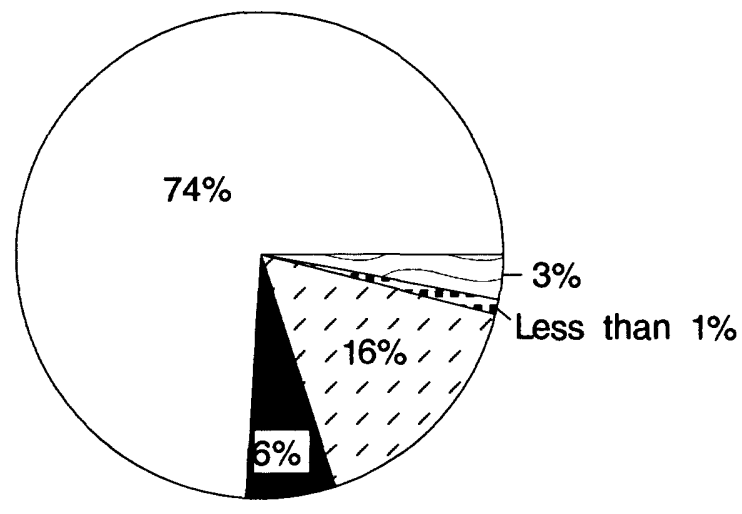

Total $=1,911.12$ million gallons per day

\section{EXPLANATION}

PUBLC-SUPPLY WITHDRAWALS

SELF-SUPPUED COMMERCIAL WITHDRAWALS

$P$ SELF-SUPPUED INDUSTRIAL WITHDRAWALS

A.. ESTIMATED IRRIGATION WATER WITHDRAWALS MINING WITHDRAWALS

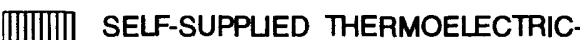
POWER WITHDRAWALS DI ESTIMATED SELF-SUPPUED

ESTIMATED SELF-SUPPUED LIVESTOCK WITHDRAWALS

\section{GROUND-WATER WITHDRAWALS}

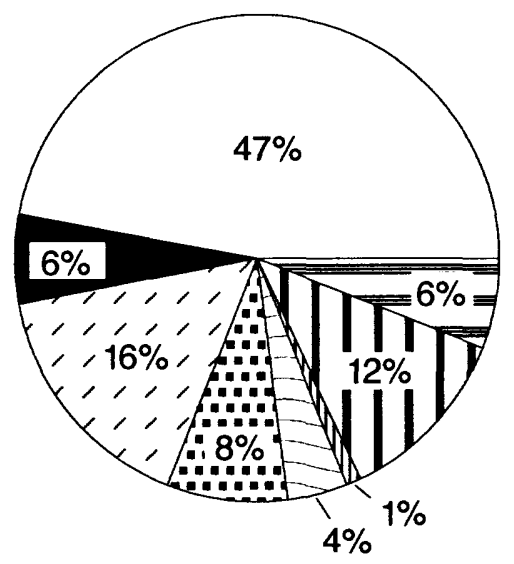

Total $=945.29$ million gallons per day

TOTAL WATER WITHDRAWALS (excluding self-supplied thermoelectricpower withdrawals)

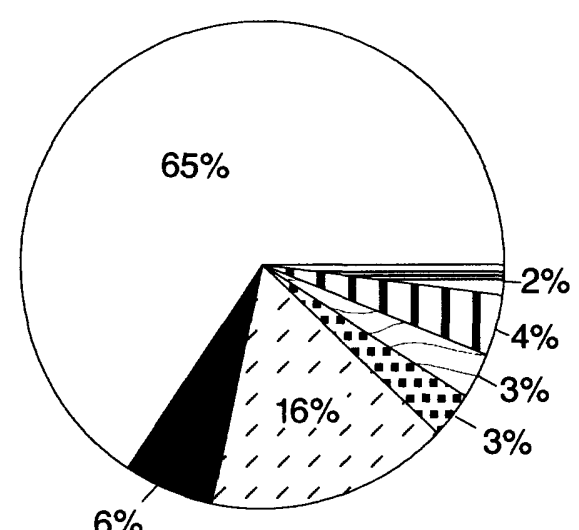

Total $=2,847.38$ million gallons per day

Figure 18. Surface-water, ground-water, and total water withdrawals by water-use category for Illinois, 1990. 
Bowman, J.A., and Kimpel, B.C., 1991, Irrigation practices in Illinois: Illinois State Water Survey Research Report 118, 56 p.

Kirk, J.R., 1987, Water withdrawals in Illinois: Illinois State Water Survey Circular 167, 43 p.

Office of Management and Budget, 1987, Standard industrial classification manual 1987: Washington, D.C., U.S. Government Printing Office.

Seaber, P.R., Kapinos, F.P., and Knapp, G.L., 1987, Hydrologic unit maps: U.S. Geological Survey Water-Supply Paper 2294, 63 p.

Solley, W.B., Pierce, R.R., and Perlman, H.A., 1993, Estimated use of water in the United States in 1990: U.S. Geological Survey Circular 1081, 76 p.

U.S. Bureau of Census, 1989, Census of Agriculture 1987; Volume 1-Geographic areas series, Part 13-Illinois, State and county data: Washington D.C., U.S. Government Printing Office, 478 p.
U.S. Geological Survey, 1985, National water summary 1984-Hydrologic events, selected water-quality trends, and ground-water resources: U.S. Geological Survey Water-Supply Paper 2275, $467 \mathrm{p}$.

U.S. National Oceanic and Atmospheric Administration, 1991a, Climatological Data-Illinois, May 1990:

U.S. National Oceanic and Atmospheric Administration, v. 95 , no. 5,28 p.

1991b, Climatological Data-Illinois, June 1990:

U.S. National Oceanic and Atmospheric Administration, v. 95 , no. 6,28 p.

1991c, Climatological Data-Illinois, July 1990:

U.S. National Oceanic and Atmospheric Administration, v. 95 , no. 7, 28 p.

1991d, Climatological Data-Illinois, August 1990: U.S. National Oceanic and Atmospheric Administration, v. 95 , no. 8,28 p. 
TERMS USED IN THIS REPORT (from Solley and others, 1993):

Animal specialties. Water use associated with the production of fish in captivity except fish hatcheries, fur-bearing animals in captivity, horses, rabbits, and pets.

Commercial water use. Water for motels, hotels, restaurants, office buildings, other commercial facilities, and institutions. The water may be obtained from a public supply or may be self supplied.

Consumptive use. That part of water withdrawn that is evaporated, transpired, incorporated into products or crops, consumed by humans or livestock, or otherwise removed from the immediate water environment.

Conveyance loss. Water that is lost in transit from a pipe, canal, conduit, or ditch by leakage or evaporation. Generally, the water is not available for further use; however, leakage from an irrigation ditch, for example, may percolate to a groundwater source and be available for further use.

Delivery. The amount of water delivered to the point of use.

Domestic water use. Water for household purposes, such as drinking, food preparation, bathing, washing clothes and dishes, flushing toilets, and watering lawns and gardens. Also called residential water use.

Freshwater. Water that contains less than $1,000 \mathrm{mg} / \mathrm{L}$ (milligrams per liter) of dissolved solids; generally, more than $500 \mathrm{mg} / \mathrm{L}$ of dissolved solids is undesirable for drinking and many industrial uses.

Gigawatt-hour (GWh). One billion watt-hours.

Ground water. Generally all subsurface water as distinct from surface water; specifically, that part of the subsurface water in the saturated zone (a zone in which all voids are filled with water) where the water is under pressure greater than atmospheric.

Industrial water use. Water used for industrial purposes such as fabrication, processing, washing, and cooling, and includes such industries as steel, chemical and allied products, paper and allied products, mining, and petroleum refining. The water may be obtained from a public supply or may be self supplied.
Instream use. Water use that is used, but not withdrawn, from a ground- or surface-water source for such purposes as hydroelectric power generation, navigation, water-quality improvement, fish propagation, and recreation. Sometimes called nonwithdrawal use or in-channel use.

Irrigation water use. Artificial application of water on lands to assist in the growing of crops and pastures or to maintain vegetative growth in recreational lands, such as parks and golf courses.

Livestock water use. Water for livestock watering, feed lots, dairy operations, fish farming, and other on-farm needs. Livestock as used here includes cattle, sheep, goats, hogs, and poultry.

Million gallons per day (Mgal/d). A rate of flow of water.

Mining water use. Water use for the extraction of minerals occurring naturally including solids, such as coal and ores; liquids, such as crude petroleum; and gases, such as natural gas. Also includes uses associated with quarrying, well operations (dewatering), milling (crushing, screening, washing, floatation, and so forth), and other preparations customarily done at the mine site or as part of a mining activity.

Offstream use. Water withdrawn or diverted from a ground- or surface-water source for public-water supply, industry, irrigation, livestock, thermoelectric-power generation, and other uses. Sometimes called off-channel use or withdrawal use.

Per capita use. The average amount of water used per person during a standard time period, generally per day.

Public supply. Water withdrawn by public and private water suppliers and delivered to groups of users. Public suppliers provide water for a variety of uses, such as domestic, commercial, thermoelectric-power generation, industrial, and public water use.

Public-supply deliveries. Water provided to users through a public-supply distribution system.

Saline water. Water that contains more than 1,000 milligrams per liter of dissolved solids.

Self-supplied water. Water withdrawn from a surface- or ground-water source by a user rather than being obtained from a public supply.

Surface water. An open body of water, such as a stream or a lake. 
-Thermoelectric-power water use. Water used in the process of the generation of thermoelectric power. The water may be obtained from a public supply or may be self supplied.
Withdrawal. Water removed from the ground or diverted from a surface-water source for use. 
TABLES 
Table 1. Public-supply water withdrawals and domestic water use in Illinois, by county, 1990

[All values in million gallons per day]

\begin{tabular}{|c|c|c|c|c|c|c|}
\hline \multirow[b]{2}{*}{ County } & \multicolumn{3}{|c|}{ Public-supply withdrawals } & \multicolumn{3}{|c|}{ Domestic water use } \\
\hline & $\begin{array}{l}\text { Ground } \\
\text { water }\end{array}$ & $\begin{array}{c}\text { Surface } \\
\text { water }\end{array}$ & Total & $\begin{array}{c}\text { Public-supplied } \\
\text { deliveries }\end{array}$ & $\begin{array}{l}\text { Self-supplied } \\
\text { withdrawals }\end{array}$ & Total \\
\hline Adams & 1.67 & 7.06 & 8.73 & 4.53 & 0.37 & 4.90 \\
\hline Alexander & .36 & 1.42 & 1.78 & .81 & .07 & .88 \\
\hline Bond & .07 & .94 & 1.01 & .63 & .58 & 1.21 \\
\hline Boone & 3.83 & .00 & 3.83 & 1.64 & 1.21 & 2.85 \\
\hline Brown & .09 & .00 & .09 & .20 & .22 & .42 \\
\hline Bureau & 3.18 & .00 & 3.18 & 2.61 & 1.10 & 3.71 \\
\hline Calhoun & .34 & .00 & .34 & .13 & .29 & .42 \\
\hline Carroll & .06 & .00 & .06 & 1.11 & .64 & 1.75 \\
\hline Cass & 2.97 & .04 & 3.01 & .83 & .22 & 1.05 \\
\hline Champaign & 20.57 & .00 & 20.57 & 10.29 & 2.24 & 12.53 \\
\hline Christian & 1.25 & 2.16 & 3.41 & 1.95 & .68 & 2.63 \\
\hline Clark & 1.23 & .00 & 1.23 & .73 & .42 & 1.15 \\
\hline Clay & .00 & .88 & .88 & .59 & .44 & 1.03 \\
\hline Clinton & .25 & 2.02 & 2.27 & 2.05 & .56 & 2.61 \\
\hline Coles & .84 & 4.19 & 5.03 & 3.13 & .44 & 3.57 \\
\hline Cook & 20.04 & $1,102.83$ & $1,122.87$ & 482.15 & .47 & 482.62 \\
\hline Crawford & 2.05 & .00 & 2.05 & .96 & .43 & 1.39 \\
\hline Cumberland & .28 & .00 & .28 & .34 & .43 & .77 \\
\hline De Kalb & 7.79 & .00 & 7.79 & 4.82 & 2.16 & 6.98 \\
\hline De Witt & 2.21 & .00 & 2.21 & .85 & .49 & 1.34 \\
\hline Douglas & 1.24 & .00 & 1.24 & .81 & .56 & 1.37 \\
\hline Du Page & 86.35 & .00 & 86.35 & 61.32 & 9.30 & 70.62 \\
\hline Edgar & .34 & 1.20 & 1.54 & .89 & .49 & 1.38 \\
\hline Edwards & .02 & .11 & .13 & .32 & .33 & .65 \\
\hline Effingham & .24 & 2.21 & 2.45 & 1.30 & 1.01 & 2.31 \\
\hline Fayette & .09 & 1.20 & 1.29 & .79 & .72 & 1.51 \\
\hline Ford & 1.68 & .00 & 1.68 & .83 & .20 & 1.03 \\
\hline Franklin & .00 & 12.52 & 12.52 & 2.79 & .59 & 3.38 \\
\hline Fulton & 1.34 & 1.38 & 2.72 & 2.33 & .49 & 2.82 \\
\hline Gallatin & 2.68 & .04 & 2.72 & .46 & .11 & .57 \\
\hline Greene & .36 & .30 & .66 & .89 & .28 & 1.17 \\
\hline Grundy & 2.53 & .00 & 2.53 & 2.27 & .89 & 3.16 \\
\hline Hamilton & .02 & .00 & .02 & .35 & .37 & .72 \\
\hline Hancock & .21 & 1.04 & 1.25 & .84 & .81 & 1.65 \\
\hline Hardin & .12 & .15 & .27 & .38 & .06 & .44 \\
\hline Henderson & 5.90 & .00 & 5.90 & .21 & .46 & .67 \\
\hline Henry & 4.76 & .00 & 4.76 & 3.93 & 1.45 & 5.38 \\
\hline Iroquois & 2.17 & .00 & 2.17 & 1.50 & .79 & 2.29 \\
\hline Jacksson & .07 & 7.93 & 8.00 & 4.34 & .26 & 4.60 \\
\hline Jasper & .40 & .00 & .40 & .27 & .52 & .79 \\
\hline Jefferson & .00 & 1.28 & 1.28 & 2.28 & .70 & 2.98 \\
\hline Jersey & .90 & .00 & .90 & 1.40 & .16 & 1.56 \\
\hline Jo Daviess & 2.44 & .00 & 2.44 & 1.33 & 1.05 & 2.38 \\
\hline Johnson & .02 & .62 & .64 & .32 & .46 & .78 \\
\hline Kane & 28.82 & 9.08 & 37.90 & 25.89 & 3.49 & 29.38 \\
\hline Kankakee & 2.23 & 11.29 & 13.52 & 5.14 & 2.17 & 7.31 \\
\hline Kendall & 2.01 & .00 & 2.01 & 1.16 & 2.65 & 3.81 \\
\hline Knox & 1.39 & .00 & 1.39 & 3.63 & .51 & 4.14 \\
\hline Lake & 17.20 & 41.13 & 58.33 & 35.70 & 10.85 & 46.55 \\
\hline La Salle & 10.83 & 3.41 & 14.24 & 8.45 & 1.36 & 9.81 \\
\hline Lawrence & 1.68 & .00 & 1.68 & .79 & .34 & 1.13 \\
\hline Lee & 3.94 & .00 & 3.94 & 2.45 & 1.10 & 3.55 \\
\hline Livingston & 1.71 & 2.05 & 3.76 & 2.02 & 1.01 & 3.03 \\
\hline Logan & 3.30 & .00 & 3.30 & 1.80 & .51 & 2.31 \\
\hline McDonough & 1.45 & 1.73 & 3.18 & 2.13 & .41 & 2.54 \\
\hline
\end{tabular}


Table 1. Public-supply water withdrawals and domestic water use in Illinois, by county, 1990 - Continued

\begin{tabular}{|c|c|c|c|c|c|c|}
\hline \multirow[b]{2}{*}{ County } & \multicolumn{3}{|c|}{ Public-supply withdrawals } & \multicolumn{3}{|c|}{ Domestic water use } \\
\hline & $\begin{array}{l}\begin{array}{c}\text { Ground } \\
\text { water }\end{array} \\
\end{array}$ & $\begin{array}{c}\text { Surface } \\
\text { water }\end{array}$ & Total & $\begin{array}{c}\begin{array}{c}\text { Public-supplied } \\
\text { deliveries }\end{array} \\
\end{array}$ & $\begin{array}{l}\text { Self-supplied } \\
\text { withdrawals }\end{array}$ & Total \\
\hline McHenry & 14.52 & 0.00 & 14.52 & 9.36 & 6.65 & 16.01 \\
\hline McLean & 5.78 & 3.35 & 9.13 & 8.30 & 1.12 & 9.42 \\
\hline Macon & 1.31 & 32.56 & 33.87 & 8.51 & .67 & 9.18 \\
\hline Macoupin & .14 & 3.62 & 3.76 & 2.62 & 1.10 & 3.72 \\
\hline Madison & 12.28 & 43.83 & 56.11 & 17.40 & 1.16 & 18.56 \\
\hline Marion & .03 & 6.87 & 6.90 & 2.44 & .61 & 3.05 \\
\hline Marshall & 1.74 & .00 & 1.74 & .70 & .30 & 1.00 \\
\hline Mason & 1.16 & .00 & 1.16 & .72 & .60 & 1.32 \\
\hline Massac & 1.66 & .00 & 1.66 & .94 & .27 & 1.21 \\
\hline Menard & .71 & .00 & .71 & .53 & .39 & .92 \\
\hline Mercer & .95 & .00 & .95 & .93 & .96 & 1.89 \\
\hline Monroe & .13 & .49 & .62 & 1.01 & .71 & 1.72 \\
\hline Montgomery & .58 & 2.22 & 2.80 & 1.53 & .85 & 2.38 \\
\hline Morgan & .07 & .69 & .76 & 2.23 & .52 & 2.75 \\
\hline Moultrie & 1.08 & .00 & 1.08 & .73 & .29 & 1.02 \\
\hline Ogle & 5.62 & .00 & 5.62 & 2.57 & 2.05 & 4.62 \\
\hline Peoria & 19.77 & 6.92 & 26.69 & 13.02 & .85 & 13.87 \\
\hline Perry & .07 & .48 & .55 & .91 & .79 & 1.70 \\
\hline Piatt & 1.93 & .00 & 1.93 & .83 & .38 & 1.21 \\
\hline Pike & .95 & .51 & 1.46 & .87 & .44 & 1.31 \\
\hline Pope & .00 & .08 & .08 & .34 & .04 & .38 \\
\hline Pulaski & .50 & .00 & .50 & .44 & .22 & .66 \\
\hline Putnam & .49 & .00 & .49 & .43 & .18 & .61 \\
\hline Randolph & .77 & 2.60 & 3.37 & 2.14 & .62 & 2.76 \\
\hline Richland & .13 & 1.44 & 1.57 & .80 & .32 & 1.12 \\
\hline Rock Island & 2.80 & 14.65 & 17.45 & 14.56 & .95 & 15.51 \\
\hline St. Clair & .19 & 19.77 & 19.96 & 17.29 & 3.11 & 20.40 \\
\hline Saline & .00 & .34 & .34 & 1.96 & .27 & 2.23 \\
\hline Sangamon & 2.31 & 31.66 & 33.97 & 12.06 & 1.38 & 13.44 \\
\hline Schuyler & .64 & .00 & .64 & .32 & .26 & .58 \\
\hline Scott & .98 & .00 & .98 & .23 & .22 & .45 \\
\hline Shelby & 1.07 & 1.46 & 2.53 & .78 & .88 & 1.66 \\
\hline Stark & .70 & .00 & .70 & .31 & .19 & .50 \\
\hline Stephenson & 4.80 & .00 & 4.80 & 3.88 & 1.08 & 4.96 \\
\hline Tazewell & 15.69 & .58 & 16.27 & 8.60 & .75 & 9.35 \\
\hline Union & 1.25 & .15 & 1.40 & .91 & .48 & 1.39 \\
\hline Vermilion & 1.47 & 9.99 & 11.46 & 5.18 & 1.30 & 6.48 \\
\hline Wabash & .69 & 1.13 & 1.82 & .83 & .28 & 1.11 \\
\hline Warren & 2.36 & .00 & 2.36 & 1.08 & .41 & 1.49 \\
\hline Washington & .11 & .70 & .81 & 1.00 & .22 & 1.22 \\
\hline Wayne & .10 & 1.15 & 1.25 & .73 & .68 & 1.41 \\
\hline White & 1.39 & .00 & 1.39 & .98 & .39 & 1.37 \\
\hline Whiteside & 5.03 & .00 & 5.03 & 4.10 & 2.27 & 6.37 \\
\hline Will & 33.83 & .00 & 33.83 & 21.79 & 10.68 & 32.47 \\
\hline Williamson & .00 & 2.36 & 2.36 & 4.47 & .14 & 4.61 \\
\hline Winnebago & 36.76 & 0.00 & 36.76 & 19.05 & 6.32 & 25.37 \\
\hline Woodford & 1.64 & 5.68 & 7.32 & 1.49 & 1.04 & 2.53 \\
\hline Total & $\overline{443.70}$ & $1,415.49$ & $1,859.19$ & 903.56 & $\overline{115.31}$ & $1,018.87$ \\
\hline
\end{tabular}


Table 2. Public-supply withdrawals and domestic water use in Illinois, by hydrologic unit, 1990 [All values in million gallons per day]

\begin{tabular}{|c|c|c|c|c|c|c|}
\hline \multirow[b]{2}{*}{$\begin{array}{c}\text { Hydrologic } \\
\text { unit }\end{array}$} & \multicolumn{3}{|c|}{ Public-supply withdrawals } & \multicolumn{3}{|c|}{ Domestic water use } \\
\hline & $\begin{array}{l}\text { Ground } \\
\text { water }\end{array}$ & $\begin{array}{c}\text { Surface } \\
\text { water }\end{array}$ & Total & $\begin{array}{c}\text { Public-supplied } \\
\text { deliveries }\end{array}$ & $\begin{array}{l}\text { Self-supplied } \\
\text { withdrawals }\end{array}$ & Total \\
\hline 04040001 & 0.00 & 0.00 & 0.00 & 15.91 & 0.02 & 15.93 \\
\hline 04040002 & .10 & .00 & .10 & 19.21 & 1.45 & 20.66 \\
\hline 04060200 & .00 & $1,146.33$ & $1,146.33$ & .00 & .00 & .00 \\
\hline 05120108 & .07 & .37 & .44 & .99 & .26 & 1.25 \\
\hline 05120109 & 3.61 & 9.62 & 13.23 & 8.88 & 2.08 & 10.96 \\
\hline 05120111 & 2.83 & 1.20 & 4.03 & 1.29 & .67 & 1.96 \\
\hline 05120112 & 4.36 & 1.75 & 6.11 & 6.49 & 2.67 & 9.16 \\
\hline 05120113 & 2.01 & 1.24 & 3.25 & 1.45 & .61 & 2.06 \\
\hline 05120114 & 1.22 & 8.09 & 9.31 & 3.61 & 2.59 & 6.20 \\
\hline 05120115 & .12 & .17 & .29 & 2.10 & .95 & 3.05 \\
\hline 05140203 & .39 & .23 & .62 & .93 & .26 & 1.19 \\
\hline 05140204 & 2.23 & 1.04 & 3.27 & 4.51 & .87 & 5.38 \\
\hline 05140206 & 2.18 & 2.04 & 4.22 & 1.36 & .62 & 1.98 \\
\hline 07060005 & 3.66 & .00 & 3.66 & 2.10 & 1.43 & 3.53 \\
\hline 07080101 & .88 & 14.65 & 15.53 & 4.29 & .91 & 5.20 \\
\hline 07080104 & 9.65 & .58 & 10.23 & 6.49 & 2.37 & 8.86 \\
\hline 07090001 & .65 & .00 & .65 & .41 & .15 & .56 \\
\hline 07090003 & 5.22 & .00 & 5.22 & 10.13 & 3.22 & 13.35 \\
\hline 07090004 & .45 & .00 & .45 & 2.17 & .71 & 2.88 \\
\hline 07090005 & 50.12 & .00 & 50.12 & 18.52 & 7.46 & 25.98 \\
\hline 07090006 & 14.00 & .00 & 14.00 & 17.46 & 7.47 & 24.93 \\
\hline 07090007 & 3.49 & .00 & 3.49 & 9.63 & 2.22 & 11.85 \\
\hline 07110001 & 1.31 & 7.23 & 8.54 & 2.37 & .42 & 2.79 \\
\hline 07110004 & 1.07 & .00 & 1.07 & 1.86 & .58 & 2.44 \\
\hline 07110009 & 4.66 & 8.91 & 13.57 & 3.78 & .40 & 4.18 \\
\hline 07120001 & 3.28 & 11.26 & 14.54 & 12.10 & 5.65 & 17.75 \\
\hline 07120002 & 2.56 & .00 & 2.56 & 2.53 & 1.14 & 3.67 \\
\hline 07120003 & 11.08 & .00 & 11.08 & 223.02 & 1.63 & 224.65 \\
\hline 07120004 & 132.84 & .00 & 132.84 & 263.73 & 18.11 & 281.84 \\
\hline 07120005 & 4.38 & .03 & 4.41 & 5.50 & 2.96 & 8.46 \\
\hline 07120006 & 25.28 & .00 & 25.28 & 70.59 & 8.27 & 78.86 \\
\hline 07120007 & 32.73 & 9.08 & 41.81 & 28.99 & 6.09 & 35.08 \\
\hline 07130001 & 27.30 & 6.84 & 34.14 & 8.81 & 2.26 & 11.07 \\
\hline 07130002 & 1.92 & 5.46 & 7.38 & 4.28 & 1.30 & 5.58 \\
\hline 07130003 & 19.80 & 1.54 & 21.34 & 13.64 & 1.53 & 15.17 \\
\hline 07130004 & 4.84 & 9.60 & 14.44 & 5.70 & 1.19 & 6.89 \\
\hline 07130005 & 4.89 & .00 & 4.89 & 11.26 & 1.67 & 12.93 \\
\hline 07130006 & 7.14 & 32.56 & 39.70 & 11.70 & 1.72 & 13.42 \\
\hline 07130007 & 1.26 & 33.76 & 35.02 & 7.20 & 1.39 & 8.59 \\
\hline 07130008 & 2.57 & .11 & 2.68 & 6.60 & 1.22 & 7.82 \\
\hline 07130009 & 11.30 & .00 & 11.30 & 9.86 & 1.98 & 11.84 \\
\hline 07130010 & 1.60 & 1.93 & 3.53 & 2.75 & .95 & 3.70 \\
\hline 07130011 & 3.08 & 1.42 & 4.50 & 5.27 & 1.45 & 6.72 \\
\hline 07130012 & .28 & 3.02 & 3.30 & 2.76 & 1.04 & 3.80 \\
\hline 07140101 & 7.70 & 51.76 & 59.46 & 13.58 & 2.10 & 15.68 \\
\hline 07140105 & 1.59 & 2.02 & 3.61 & 2.30 & .53 & 2.83 \\
\hline 07140106 & .08 & 24.43 & 24.51 & 12.31 & 2.30 & 14.61 \\
\hline 07140108 & .40 & .10 & .50 & .87 & .31 & 1.18 \\
\hline 07140201 & 19.69 & 1.33 & 21.02 & 4.63 & 1.83 & 6.46 \\
\hline 07140202 & .34 & 7.60 & 7.94 & 4.03 & 1.66 & 5.69 \\
\hline 07140203 & .58 & 3.75 & 4.33 & 2.14 & 1.17 & 3.31 \\
\hline 07140204 & .91 & 4.44 & 5.35 & 21.47 & 3.47 & 24.94 \\
\hline Total & 443.70 & $1,415.49$ & $1,859.19$ & $\overline{903.56}$ & $\overline{115.31}$ & $1,018.87$ \\
\hline
\end{tabular}


Table 3. Population served by public-supply facilities and self-supplied population in Illinois, by county, 1990

\begin{tabular}{|c|c|c|c|c|c|}
\hline County & $\begin{array}{c}\text { Public-supplied } \\
\text { population }\end{array}$ & $\begin{array}{c}\text { Self-supplied } \\
\text { population } \\
\end{array}$ & County & $\begin{array}{c}\text { Public-supplied } \\
\text { population }\end{array}$ & $\begin{array}{c}\text { Self-supplied } \\
\text { population } \\
\end{array}$ \\
\hline $\begin{array}{l}\text { Adams } \\
\text { Alexander } \\
\text { Bond } \\
\text { Boone } \\
\text { Brown }\end{array}$ & $\begin{array}{r}60,970 \\
9,710 \\
7,070 \\
17,630 \\
2,810\end{array}$ & $\begin{array}{r}5,120 \\
920 \\
7,920 \\
13,180 \\
3,030\end{array}$ & $\begin{array}{l}\text { McHenry } \\
\text { McLean } \\
\text { Macon } \\
\text { Macoupin } \\
\text { Madison }\end{array}$ & $\begin{array}{r}110,680 \\
114,060 \\
108,190 \\
32,610 \\
233,410\end{array}$ & $\begin{array}{r}72,560 \\
15,120 \\
9,020 \\
15,070 \\
15,830\end{array}$ \\
\hline $\begin{array}{l}\text { Bureau } \\
\text { Calhoun } \\
\text { Carroll } \\
\text { Cass } \\
\text { Champaign }\end{array}$ & $\begin{array}{r}24,630 \\
1,300 \\
10,360 \\
10,420 \\
141,980\end{array}$ & $\begin{array}{r}11,060 \\
4,020 \\
6,440 \\
3,020 \\
31,040\end{array}$ & $\begin{array}{l}\text { Marion } \\
\text { Marshall } \\
\text { Mason } \\
\text { Massac } \\
\text { Menard }\end{array}$ & $\begin{array}{r}32,620 \\
8,760 \\
8,200 \\
11,290 \\
5,860\end{array}$ & $\begin{array}{l}8,940 \\
4,090 \\
8,070 \\
3,460 \\
5,300\end{array}$ \\
\hline $\begin{array}{l}\text { Christian } \\
\text { Clark } \\
\text { Clay } \\
\text { Clinton } \\
\text { Coles }\end{array}$ & $\begin{array}{r}25,140 \\
9,820 \\
8,080 \\
26,560 \\
45,270\end{array}$ & $\begin{array}{l}9,280 \\
6,100 \\
6,380 \\
7,380 \\
6,370\end{array}$ & $\begin{array}{l}\text { Mercer } \\
\text { Monroe } \\
\text { Montgomery } \\
\text { Morgan } \\
\text { Moultrie }\end{array}$ & $\begin{array}{r}7,650 \\
13,110 \\
19,120 \\
29,300 \\
9,670\end{array}$ & $\begin{array}{r}9,640 \\
9,310 \\
11,610 \\
7,100 \\
4,260\end{array}$ \\
\hline $\begin{array}{l}\text { Cook } \\
\text { Crawford } \\
\text { Cumberland } \\
\text { De Kalb } \\
\text { De Witt }\end{array}$ & $\begin{array}{r}5,099,990 \\
13,230 \\
4,450 \\
54,350 \\
9,880\end{array}$ & $\begin{array}{r}5,080 \\
6,230 \\
6,220 \\
23,580 \\
6,640\end{array}$ & $\begin{array}{l}\text { Ogle } \\
\text { Peoria } \\
\text { Perry } \\
\text { Piatt } \\
\text { Pike }\end{array}$ & $\begin{array}{r}25,400 \\
171,350 \\
10,960 \\
10,230 \\
11,520\end{array}$ & $\begin{array}{r}20,560 \\
11,480 \\
10,450 \\
5,320 \\
6,060\end{array}$ \\
\hline $\begin{array}{l}\text { Douglas } \\
\text { Du Page } \\
\text { Edgar } \\
\text { Edwards } \\
\text { Effingham }\end{array}$ & $\begin{array}{r}11,240 \\
680,130 \\
12,460 \\
3,240 \\
16,960\end{array}$ & $\begin{array}{r}8,220 \\
101,540 \\
7,140 \\
4,200 \\
14,740\end{array}$ & $\begin{array}{l}\text { Pope } \\
\text { Pulaski } \\
\text { Putnam } \\
\text { Randolph } \\
\text { Richland }\end{array}$ & $\begin{array}{r}3,900 \\
4,560 \\
3,910 \\
26,350 \\
11,800\end{array}$ & $\begin{array}{r}470 \\
2,960 \\
1,820 \\
8,230 \\
4,740\end{array}$ \\
\hline $\begin{array}{l}\text { Fayette } \\
\text { Ford } \\
\text { Franklin } \\
\text { Fulton } \\
\text { Gallatin }\end{array}$ & $\begin{array}{r}10,430 \\
11,540 \\
32,870 \\
31,310 \\
5,570\end{array}$ & $\begin{array}{r}10,460 \\
2,740 \\
7,450 \\
6,770 \\
1,340\end{array}$ & $\begin{array}{l}\text { Rock Island } \\
\text { St. Clair } \\
\text { Saline } \\
\text { Sangamon } \\
\text { Schuyler }\end{array}$ & $\begin{array}{r}139,240 \\
222,340 \\
23,160 \\
159,510 \\
3,950\end{array}$ & $\begin{array}{r}9,480 \\
40,510 \\
3,390 \\
18,880 \\
3,550\end{array}$ \\
\hline $\begin{array}{l}\text { Greene } \\
\text { Grundy } \\
\text { Hamilton } \\
\text { Hancock } \\
\text { Hardin }\end{array}$ & $\begin{array}{r}11,440 \\
22,600 \\
3,780 \\
10,090 \\
4,380\end{array}$ & $\begin{array}{r}3,880 \\
9,740 \\
4,720 \\
11,280 \\
810\end{array}$ & $\begin{array}{l}\text { Scott } \\
\text { Shelby } \\
\text { Stark } \\
\text { Stephenson } \\
\text { Tazewell }\end{array}$ & $\begin{array}{r}2,570 \\
9,350 \\
3,950 \\
37,250 \\
113,630\end{array}$ & $\begin{array}{r}3,070 \\
12,910 \\
2,580 \\
10,800 \\
10,060\end{array}$ \\
\hline $\begin{array}{l}\text { Henderson } \\
\text { Henry } \\
\text { Iroquois } \\
\text { Jackson } \\
\text { Jasper }\end{array}$ & $\begin{array}{r}1,660 \\
36,650 \\
19,840 \\
56,630 \\
3,020\end{array}$ & $\begin{array}{r}6,440 \\
14,510 \\
10,950 \\
4,440 \\
7,590\end{array}$ & $\begin{array}{l}\text { Union } \\
\text { Vermilion } \\
\text { Wabash } \\
\text { Warren } \\
\text { Washington }\end{array}$ & $\begin{array}{r}11,350 \\
70,170 \\
9,540 \\
13,500 \\
12,070\end{array}$ & $\begin{array}{r}6,270 \\
18,090 \\
3,570 \\
5,680 \\
2,890\end{array}$ \\
\hline $\begin{array}{l}\text { Jefferson } \\
\text { Jersey } \\
\text { Jo Daviess } \\
\text { Johnson } \\
\text { Kane }\end{array}$ & $\begin{array}{r}28,160 \\
18,390 \\
11,280 \\
5,250 \\
279,370\end{array}$ & $\begin{array}{r}8,860 \\
2,150 \\
10,540 \\
6,100 \\
38,100\end{array}$ & $\begin{array}{l}\text { Wayne } \\
\text { White } \\
\text { Whiteside } \\
\text { Will } \\
\text { Williamson }\end{array}$ & $\begin{array}{r}8,710 \\
11,600 \\
37,450 \\
240,740 \\
55,870\end{array}$ & $\begin{array}{r}8,530 \\
4,920 \\
22,740 \\
116,570 \\
1,860\end{array}$ \\
\hline $\begin{array}{l}\text { Kankakee } \\
\text { Kendall } \\
\text { Knox } \\
\text { Lake } \\
\text { La Salle }\end{array}$ & $\begin{array}{r}66,210 \\
10,430 \\
49,360 \\
397,980 \\
92,080\end{array}$ & $\begin{array}{r}30,050 \\
28,980 \\
7,030 \\
118,440 \\
14,830\end{array}$ & $\begin{array}{c}\text { Winnebago } \\
\text { Woodford } \\
\text { Total }\end{array}$ & $\begin{array}{r}189,560 \\
18,600 \\
10,059,670\end{array}$ & $\begin{array}{r}63,350 \\
14,050 \\
1,370,920\end{array}$ \\
\hline $\begin{array}{l}\text { Lawrence } \\
\text { Lee } \\
\text { Livingston } \\
\text { Logan } \\
\text { McDonough }\end{array}$ & $\begin{array}{l}10,930 \\
23,340 \\
25,300 \\
23,920 \\
29,560\end{array}$ & $\begin{array}{r}5,040 \\
11,050 \\
14,000 \\
6,880 \\
5,680\end{array}$ & & & \\
\hline
\end{tabular}


Table 4. Population served by public-supply facilities and self-supplied population in Illinois, by hydrologic unit, 1990

\begin{tabular}{|c|c|c|}
\hline $\begin{array}{c}\text { Hydrologic } \\
\text { unit }\end{array}$ & $\begin{array}{c}\text { Public-supplied } \\
\text { population }\end{array}$ & $\begin{array}{c}\text { Self-supplied } \\
\text { population }\end{array}$ \\
\hline 04040001 & 169,740 & 170 \\
\hline 04040002 & 204,610 & 15,900 \\
\hline 04060200 & 0 & 0 \\
\hline 05120108 & 13,340 & 3,570 \\
\hline 05120109 & 119,790 & 28,870 \\
\hline 05120111 & 18,090 & 9,860 \\
\hline 05120112 & 90,760 & 38,520 \\
\hline 05120113 & 18,310 & 7,980 \\
\hline 05120114 & 49,030 & 36,370 \\
\hline 05120115 & 27,410 & 12,660 \\
\hline 05140203 & 11,280 & 3,290 \\
\hline 05140204 & 56,180 & 10,870 \\
\hline 05140206 & 16,910 & 8,110 \\
\hline 07060005 & 20,340 & 14,340 \\
\hline 07080101 & 41,800 & 9,070 \\
\hline 07080104 & 69,480 & 27,740 \\
\hline 07090001 & 4,000 & 1,570 \\
\hline 07090003 & 98,570 & 32,200 \\
\hline 07090004 & 21,020 & 7,140 \\
\hline 07090005 & 180,250 & 75,100 \\
\hline 07090006 & 182,630 & 80,650 \\
\hline 07090007 & 93,870 & 22,170 \\
\hline 07110001 & 32,040 & 5,830 \\
\hline 07110004 & 25,040 & 7,960 \\
\hline 07110009 & 50,350 & 5,490 \\
\hline 07120001 & 139,230 & 66,700 \\
\hline 07120002 & 34,040 & 15,690 \\
\hline 07120003 & $2,378,860$ & 17,800 \\
\hline 07120004 & $2,810,130$ & 197,680 \\
\hline 07120005 & 60,660 & 33,610 \\
\hline 07120006 & 750,930 & 90,190 \\
\hline 07120007 & 307,700 & 66,490 \\
\hline 07130001 & 100,540 & 26,180 \\
\hline 07130002 & 52,340 & 16,850 \\
\hline 07130003 & 179,460 & 20,600 \\
\hline 07130004 & 74,820 & 16,050 \\
\hline 07130005 & 146,410 & 22,140 \\
\hline 07130006 & 155,330 & 23,660 \\
\hline 07130007 & 95,640 & 19,260 \\
\hline 07130008 & 87,480 & 16,450 \\
\hline 07130009 & 129,380 & 26,710 \\
\hline 07130010 & 36,950 & 13,150 \\
\hline 07130011 & 70,080 & 19,810 \\
\hline 07130012 & 36,460 & 14,310 \\
\hline 07140101 & 177,940 & 27,980 \\
\hline 07140105 & 29,520 & 6,990 \\
\hline 07140106 & 154,700 & 30,720 \\
\hline 07140108 & 11,060 & 4,180 \\
\hline 07140201 & 63,910 & 26,210 \\
\hline 07140202 & 54,800 & 23,680 \\
\hline 07140203 & 27,870 & 15,950 \\
\hline 07140204 & 278,590 & 46,450 \\
\hline Total & $10,059,670$ & $1,370,920$ \\
\hline
\end{tabular}


Table 5. Commercial self-supplied withdrawals and deliveries from public-supply facilities for commercial use in Illinois, by county, 1990

[All values are in millions of gallons per day]

\begin{tabular}{|c|c|c|c|c|c|}
\hline \multirow[b]{2}{*}{ County } & \multicolumn{3}{|c|}{ Self-supplied withdrawals } & \multirow{2}{*}{$\begin{array}{c}\text { Deliveries } \\
\text { from } \\
\text { public-supply } \\
\text { facilities }\end{array}$} & \multirow{2}{*}{$\begin{array}{c}\text { Total self- } \\
\text { supplied } \\
\text { withdrawals } \\
\text { and } \\
\text { public-supply } \\
\text { deliveries }\end{array}$} \\
\hline & $\begin{array}{c}\text { Ground } \\
\text { water }\end{array}$ & $\begin{array}{c}\text { Surface } \\
\text { water }\end{array}$ & Total & & \\
\hline Adams & 0.00 & 0.00 & 0.00 & 1.71 & 1.71 \\
\hline Alexander & .07 & .00 & .07 & .14 & .21 \\
\hline Bond & .00 & .00 & .00 & .16 & .16 \\
\hline Boone & .00 & .00 & .00 & .11 & .11 \\
\hline Brown & .00 & .00 & .00 & .12 & .12 \\
\hline Bureau & .44 & .28 & .72 & .30 & 1.02 \\
\hline Calhoun & .58 & 9.05 & 9.63 & .03 & 9.66 \\
\hline Carroll & .14 & 7.73 & 7.87 & .11 & 7.98 \\
\hline Cass & .00 & .03 & .03 & .07 & .10 \\
\hline Champaign & 1.64 & .00 & 1.64 & 3.68 & 5.32 \\
\hline Christian & .01 & .00 & .01 & .09 & .10 \\
\hline Clark & .00 & .00 & .00 & .11 & .11 \\
\hline Clay & .00 & .00 & .00 & .14 & .14 \\
\hline Clinton & .00 & .00 & .00 & .04 & .04 \\
\hline Coles & .00 & .00 & .00 & 2.67 & 2.67 \\
\hline Cook & 3.55 & 70.57 & 74.12 & 370.60 & 444.72 \\
\hline Crawford & .00 & .00 & .00 & .56 & .56 \\
\hline Cumberland & .00 & .00 & .00 & .02 & .02 \\
\hline De Kalb & .03 & .00 & .03 & 1.51 & 1.54 \\
\hline De Witt & .04 & .00 & .04 & .01 & .05 \\
\hline Douglas & .01 & .00 & .01 & .17 & .18 \\
\hline Du Page & 1.13 & 4.91 & 6.04 & 10.91 & 16.95 \\
\hline Edgar & .00 & .00 & .00 & .01 & .01 \\
\hline Edwards & .00 & .00 & .00 & .11 & .11 \\
\hline Effingham & .00 & .00 & .00 & .06 & .06 \\
\hline Fayette & .00 & 4.05 & 4.05 & .89 & 4.94 \\
\hline Ford & .00 & .00 & .00 & .13 & .13 \\
\hline Franklin & .00 & $.00^{\prime}$ & .00 & .13 & .13 \\
\hline Fulton & .00 & 2.52 & 2.52 & .58 & 3.10 \\
\hline Gallatin & .00 & .00 & .00 & .04 & .04 \\
\hline Greene & .00 & .00 & .00 & .15 & .15 \\
\hline Grundy & .00 & .00 & .00 & .09 & .09 \\
\hline Hamilton & .00 & .00 & .00 & .00 & .00 \\
\hline Hancock & .00 & .00 & .00 & .05 & .05 \\
\hline Hardin & .00 & .00 & .00 & .01 & .01 \\
\hline Henderson & .00 & .00 & .00 & .01 & .01 \\
\hline Henry & .01 & .00 & .01 & .20 & .21 \\
\hline Iroquois & .00 & .00 & .00 & .15 & .15 \\
\hline Jackson & 24.53 & .00 & 24.53 & .29 & 24.82 \\
\hline Jasper & .00 & .00 & .00 & .00 & .00 \\
\hline Jefferson & .00 & 1.89 & 1.89 & .08 & 1.97 \\
\hline Jersey & .04 & 7.35 & 7.39 & .06 & 7.45 \\
\hline Jo Daviess & .23 & .08 & .31 & .20 & .51 \\
\hline Johnson & .00 & .00 & .00 & .00 & .00 \\
\hline Kane & .11 & .87 & .98 & 4.19 & 5.17 \\
\hline Kankakee & .05 & .00 & .05 & 2.61 & 2.66 \\
\hline Kendall & .01 & .00 & .01 & .29 & .30 \\
\hline Knox & .00 & .00 & .00 & .65 & .65 \\
\hline Lake & .82 & .00 & .82 & 8.90 & 9.72 \\
\hline La Salle & .05 & .00 & .05 & 1.02 & 1.07 \\
\hline
\end{tabular}


Table 5. Commercial self-supplied withdrawals and deliveries from public-supply facilities for commercial use in Illinois, by county, 1990-Continued

\begin{tabular}{|c|c|c|c|c|c|}
\hline \multirow[b]{2}{*}{ County } & \multicolumn{3}{|c|}{ Self-supplied withdrawals } & \multirow{2}{*}{$\begin{array}{c}\text { Deliveries } \\
\text { from } \\
\text { public-supply } \\
\text { facilities }\end{array}$} & \multirow{2}{*}{$\begin{array}{c}\text { Total self- } \\
\text { supplied } \\
\text { withdrawals } \\
\text { and } \\
\text { public-supply } \\
\text { deliveries } \\
\end{array}$} \\
\hline & $\begin{array}{c}\begin{array}{c}\text { Ground } \\
\text { water }\end{array} \\
\end{array}$ & $\begin{array}{c}\text { Surface } \\
\text { water }\end{array}$ & Total & & \\
\hline Lawrence & 0.00 & 0.00 & 0.00 & 0.12 & 0.12 \\
\hline Lee & .16 & .00 & .16 & .40 & .56 \\
\hline Livingston & .00 & .00 & .00 & .28 & .28 \\
\hline Logan & .00 & .00 & .00 & .91 & .91 \\
\hline McDonough & .00 & .00 & .00 & 1.34 & 1.34 \\
\hline McHenry & .34 & .03 & .37 & 1.44 & 1.81 \\
\hline McLean & .11 & .00 & .11 & 3.58 & 3.69 \\
\hline Macon & .08 & .00 & .08 & 20.68 & 20.76 \\
\hline Macoupin & .00 & .00 & .00 & .06 & .06 \\
\hline Madison & 2.29 & .00 & 2.29 & 4.35 & 6.64 \\
\hline Marion & .00 & .00 & .00 & .91 & .91 \\
\hline Marshall & .00 & .00 & .00 & .07 & .07 \\
\hline Mason & 6.75 & .00 & 6.75 & .05 & 6.80 \\
\hline Massac & 1.39 & .00 & 1.39 & .01 & 1.40 \\
\hline Menard & .00 & .00 & .00 & .05 & .05 \\
\hline Mercer & .00 & .00 & .00 & .11 & .11 \\
\hline Monroe & .00 & .00 & .00 & .09 & .09 \\
\hline Montgomery & .00 & .00 & .00 & .05 & .05 \\
\hline Morgan & .00 & .00 & .00 & .66 & .66 \\
\hline Moultrie & .00 & .99 & .99 & .02 & 1.01 \\
\hline Ogle & .01 & .00 & .01 & .55 & .56 \\
\hline Peoria & .00 & .00 & .00 & 7.40 & 7.40 \\
\hline Perry & .00 & .00 & .00 & .00 & .00 \\
\hline Piatt & .02 & .00 & .02 & .03 & .05 \\
\hline Pike & .00 & .00 & .00 & .17 & .17 \\
\hline Pope & .00 & .00 & .00 & .00 & .00 \\
\hline Pulaski & .16 & .00 & .16 & .11 & .27 \\
\hline Putnam & .00 & .79 & .79 & .06 & .85 \\
\hline Randolph & .00 & .00 & .00 & .21 & .21 \\
\hline Richland & .00 & .00 & .00 & .45 & .45 \\
\hline Rock Island & .01 & .02 & .03 & .34 & .37 \\
\hline St. Clair & 8.18 & .00 & 8.18 & 4.50 & 12.68 \\
\hline Saline & .00 & .00 & .00 & 1.37 & 1.37 \\
\hline Sangamon & .00 & .00 & .00 & 7.43 & 7.43 \\
\hline Schuyler & .00 & .00 & .00 & .01 & .01 \\
\hline Scott & .00 & .00 & .00 & .02 & .02 \\
\hline Shelby & .00 & .00 & .00 & .01 & .01 \\
\hline Stark & .00 & .00 & .00 & .01 & .01 \\
\hline Stephenson & .01 & .00 & .01 & .02 & .03 \\
\hline Tazewell & .01 & .00 & .01 & 1.39 & 1.40 \\
\hline Union & .85 & .00 & .85 & .07 & .92 \\
\hline Vermilion & .01 & .00 & .01 & 1.93 & 1.94 \\
\hline Wabash & .02 & .00 & .02 & .15 & .17 \\
\hline Warren & .00 & .00 & .00 & .11 & .11 \\
\hline Washington & .00 & .00 & .00 & .26 & .26 \\
\hline Wayne & .00 & .00 & .00 & .04 & .04 \\
\hline White & .00 & .00 & .00 & .02 & .02 \\
\hline Whiteside & .00 & .18 & .18 & .53 & .71 \\
\hline Will & .32 & .00 & .32 & 6.66 & 6.98 \\
\hline Williamson & .00 & 7.74 & 7.74 & .68 & 8.42 \\
\hline Winnebago & .08 & .00 & .08 & 14.14 & 14.22 \\
\hline Woodford & .00 & .00 & .00 & .21 & .21 \\
\hline Total & 54.29 & 119.08 & $\overline{173.37}$ & 498.22 & 671.59 \\
\hline
\end{tabular}


Table 6. Commercial self-supplied withdrawals and deliveries from public-supply facilities for commercial use in Illinois, by hydrologic unit, 1990

[All values are in millions of gallons per day]

\begin{tabular}{|c|c|c|c|c|c|}
\hline \multirow[b]{2}{*}{$\begin{array}{c}\text { Hydrologic } \\
\text { unit }\end{array}$} & \multicolumn{3}{|c|}{ Self-supplied withdrawals } & \multirow{2}{*}{$\begin{array}{c}\begin{array}{c}\text { Deliveries } \\
\text { from }\end{array} \\
\text { public-supply } \\
\text { facilities }\end{array}$} & \multirow{2}{*}{$\begin{array}{c}\text { Total self- } \\
\text { supplied } \\
\text { withdrawals } \\
\text { and } \\
\text { public-supply } \\
\text { deliveries }\end{array}$} \\
\hline & $\begin{array}{c}\text { Ground } \\
\text { water }\end{array}$ & $\begin{array}{c}\text { Surface } \\
\text { water }\end{array}$ & Total & & \\
\hline $\begin{array}{l}04040001 \\
04040002 \\
04060200 \\
05120108 \\
05120109\end{array}$ & $\begin{array}{r}0.00 \\
.00 \\
.00 \\
.00 \\
1.64\end{array}$ & $\begin{array}{r}0.00 \\
14.12 \\
.00 \\
.00 \\
.00\end{array}$ & $\begin{array}{r}0.00 \\
14.12 \\
.00 \\
.00 \\
1.64\end{array}$ & $\begin{array}{r}8.29 \\
8.72 \\
.00 \\
.35 \\
3.17\end{array}$ & $\begin{array}{r}8.29 \\
22.84 \\
.00 \\
.35 \\
4.81\end{array}$ \\
\hline $\begin{array}{l}05120111 \\
05120112 \\
05120113 \\
05120114 \\
05120115\end{array}$ & $\begin{array}{l}.00 \\
.01 \\
.02 \\
.00 \\
.00\end{array}$ & $\begin{array}{l}.00 \\
.00 \\
.00 \\
.00 \\
.00\end{array}$ & $\begin{array}{l}.00 \\
.01 \\
.02 \\
.00 \\
.00\end{array}$ & $\begin{array}{r}.25 \\
3.01 \\
.29 \\
.81 \\
.37\end{array}$ & $\begin{array}{r}.25 \\
3.02 \\
.31 \\
.81 \\
.37\end{array}$ \\
\hline $\begin{array}{l}05140203 \\
05140204 \\
05140206 \\
07060005 \\
07080101\end{array}$ & $\begin{array}{r}.00 \\
.00 \\
1.39 \\
.37 \\
.01\end{array}$ & $\begin{array}{r}.00 \\
.00 \\
.00 \\
7.81 \\
.02\end{array}$ & $\begin{array}{r}.00 \\
.00 \\
1.39 \\
8.18 \\
.03\end{array}$ & $\begin{array}{r}.02 \\
1.63 \\
.07 \\
.26 \\
.42\end{array}$ & $\begin{array}{r}.02 \\
1.63 \\
1.46 \\
8.44 \\
.45\end{array}$ \\
\hline $\begin{array}{l}07080104 \\
07090001 \\
07090003 \\
07090004 \\
07090005\end{array}$ & $\begin{array}{l}.00 \\
.00 \\
.01 \\
.00 \\
.20\end{array}$ & $\begin{array}{l}.00 \\
.00 \\
.00 \\
.00 \\
.18\end{array}$ & $\begin{array}{l}.00 \\
.00 \\
.01 \\
.00 \\
.38\end{array}$ & $\begin{array}{r}.36 \\
.27 \\
4.84 \\
1.54 \\
7.35\end{array}$ & $\begin{array}{r}.36 \\
.27 \\
4.85 \\
1.54 \\
7.73\end{array}$ \\
\hline $\begin{array}{l}07090006 \\
07090007 \\
07110001 \\
07110004 \\
07110009\end{array}$ & $\begin{array}{l}.03 \\
.05 \\
.00 \\
.58 \\
.08\end{array}$ & $\begin{array}{r}.00 \\
.00 \\
.00 \\
3.21 \\
.00\end{array}$ & $\begin{array}{r}.03 \\
.05 \\
.00 \\
3.79 \\
.08\end{array}$ & $\begin{array}{r}4.17 \\
.48 \\
.81 \\
.56 \\
1.79\end{array}$ & $\begin{array}{r}4.20 \\
.53 \\
.81 \\
4.35 \\
1.87\end{array}$ \\
\hline $\begin{array}{l}07120001 \\
07120002 \\
07120003 \\
07120004 \\
07120005\end{array}$ & $\begin{array}{r}.06 \\
.00 \\
.21 \\
4.94 \\
.01\end{array}$ & $\begin{array}{r}.00 \\
.00 \\
6.61 \\
50.65 \\
.00\end{array}$ & $\begin{array}{r}.06 \\
.00 \\
6.82 \\
55.59 \\
.01\end{array}$ & $\begin{array}{r}4.50 \\
.61 \\
115.28 \\
232.22 \\
.90\end{array}$ & $\begin{array}{r}4.56 \\
.61 \\
122.10 \\
287.81 \\
.91\end{array}$ \\
\hline $\begin{array}{l}07120006 \\
07120007 \\
07130001 \\
07130002 \\
07130003\end{array}$ & $\begin{array}{r}.99 \\
.14 \\
.49 \\
.00 \\
6.77\end{array}$ & $\begin{array}{r}.03 \\
5.25 \\
1.07 \\
.00 \\
2.52\end{array}$ & $\begin{array}{r}1.02 \\
5.39 \\
1.56 \\
.00 \\
9.29\end{array}$ & $\begin{array}{r}29.43 \\
5.40 \\
1.65 \\
.59 \\
6.40\end{array}$ & $\begin{array}{r}30.45 \\
10.79 \\
3.21 \\
.59 \\
15.69\end{array}$ \\
\hline $\begin{array}{l}07130004 \\
07130005 \\
07130006 \\
07130007 \\
07130008\end{array}$ & $\begin{array}{l}.00 \\
.00 \\
.10 \\
.01 \\
.00\end{array}$ & $\begin{array}{l}.00 \\
.00 \\
.00 \\
.00 \\
.00\end{array}$ & $\begin{array}{l}.00 \\
.00 \\
.10 \\
.01 \\
.00\end{array}$ & $\begin{array}{r}1.00 \\
2.60 \\
15.00 \\
1.13 \\
7.58\end{array}$ & $\begin{array}{r}1.00 \\
2.60 \\
15.10 \\
1.14 \\
7.58\end{array}$ \\
\hline $\begin{array}{l}07130009 \\
07130010 \\
07130011 \\
07130012 \\
07140101\end{array}$ & $\begin{array}{r}.16 \\
.00 \\
.05 \\
.00 \\
10.38\end{array}$ & $\begin{array}{r}.00 \\
.00 \\
12.94 \\
.00 \\
.00\end{array}$ & $\begin{array}{r}.16 \\
.00 \\
12.99 \\
.00 \\
10.38\end{array}$ & $\begin{array}{r}9.13 \\
1.32 \\
1.30 \\
.12 \\
5.53\end{array}$ & $\begin{array}{r}9.29 \\
1.32 \\
14.29 \\
.12 \\
15.91\end{array}$ \\
\hline $\begin{array}{l}07140105 \\
07140106 \\
07140108 \\
07140201 \\
07140202\end{array}$ & $\begin{array}{r}.85 \\
24.50 \\
.24 \\
.00 \\
.00\end{array}$ & $\begin{array}{r}.00 \\
9.63 \\
.00 \\
.99 \\
4.05\end{array}$ & $\begin{array}{r}.85 \\
34.13 \\
.24 \\
.99 \\
4.05\end{array}$ & $\begin{array}{r}.17 \\
.96 \\
.20 \\
1.84 \\
1.48\end{array}$ & $\begin{array}{r}1.02 \\
35.09 \\
.44 \\
2.83 \\
5.53\end{array}$ \\
\hline $\begin{array}{l}07140203 \\
07140204\end{array}$ & $\begin{array}{l}.00 \\
.00 \\
\end{array}$ & $\begin{array}{l}.00 \\
.00 \\
\end{array}$ & $\begin{array}{l}.00 \\
.00 \\
\end{array}$ & $\begin{array}{r}.19 \\
1.86\end{array}$ & $\begin{array}{r}.19 \\
1.86 \\
\end{array}$ \\
\hline Total & 54.29 & 119.08 & $\overline{173.37}$ & 498.22 & 671.59 \\
\hline
\end{tabular}




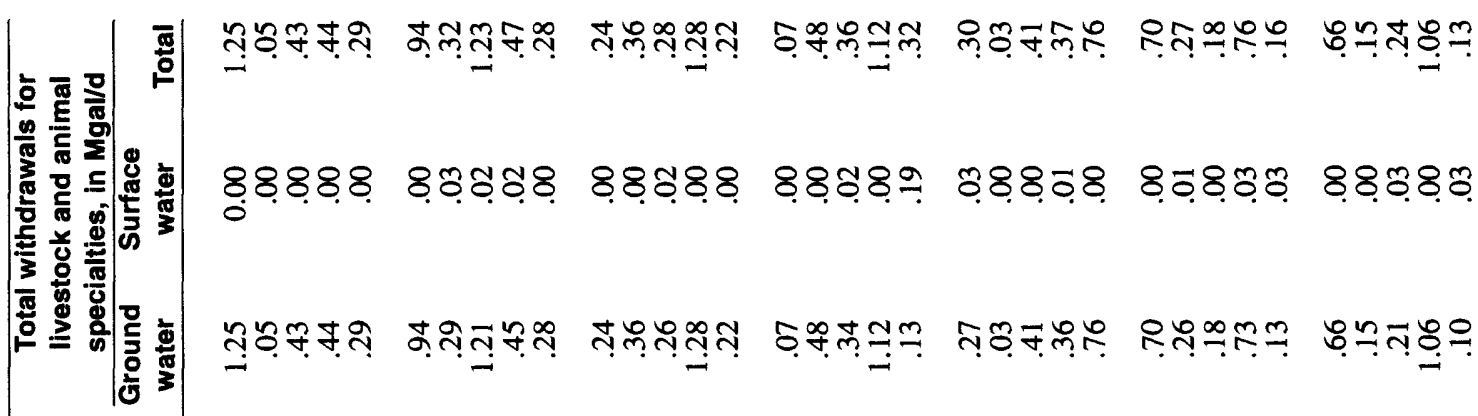

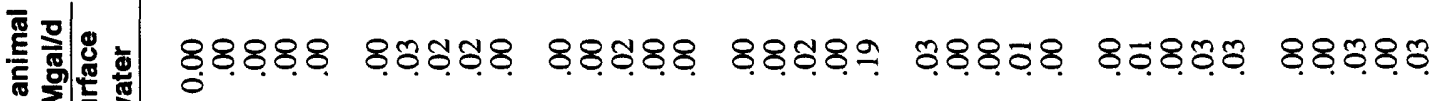

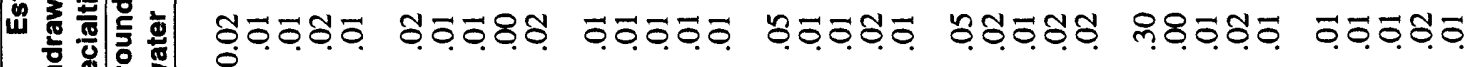

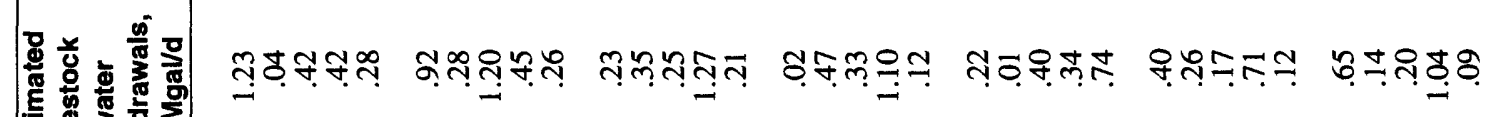

.

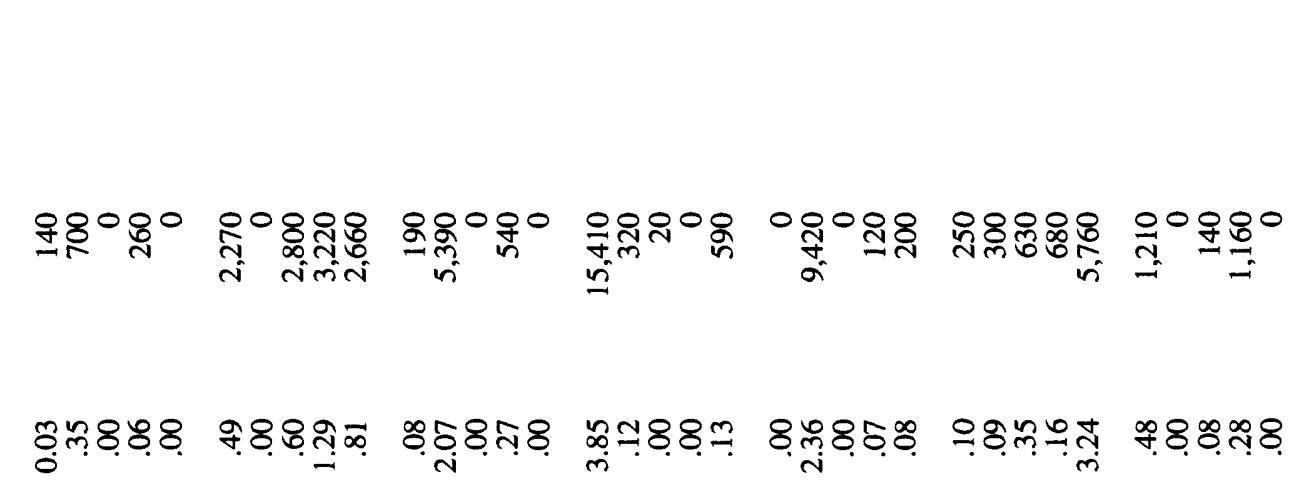

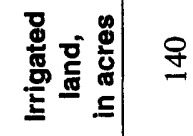

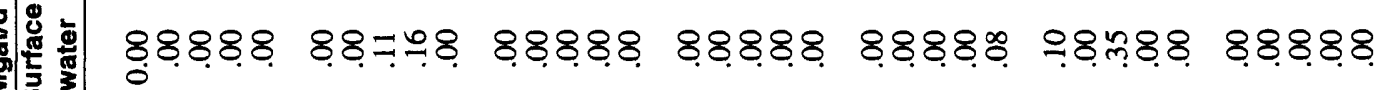

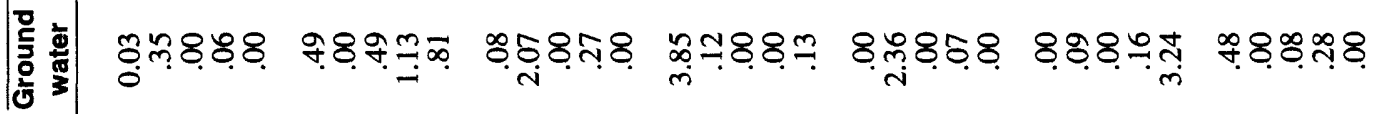




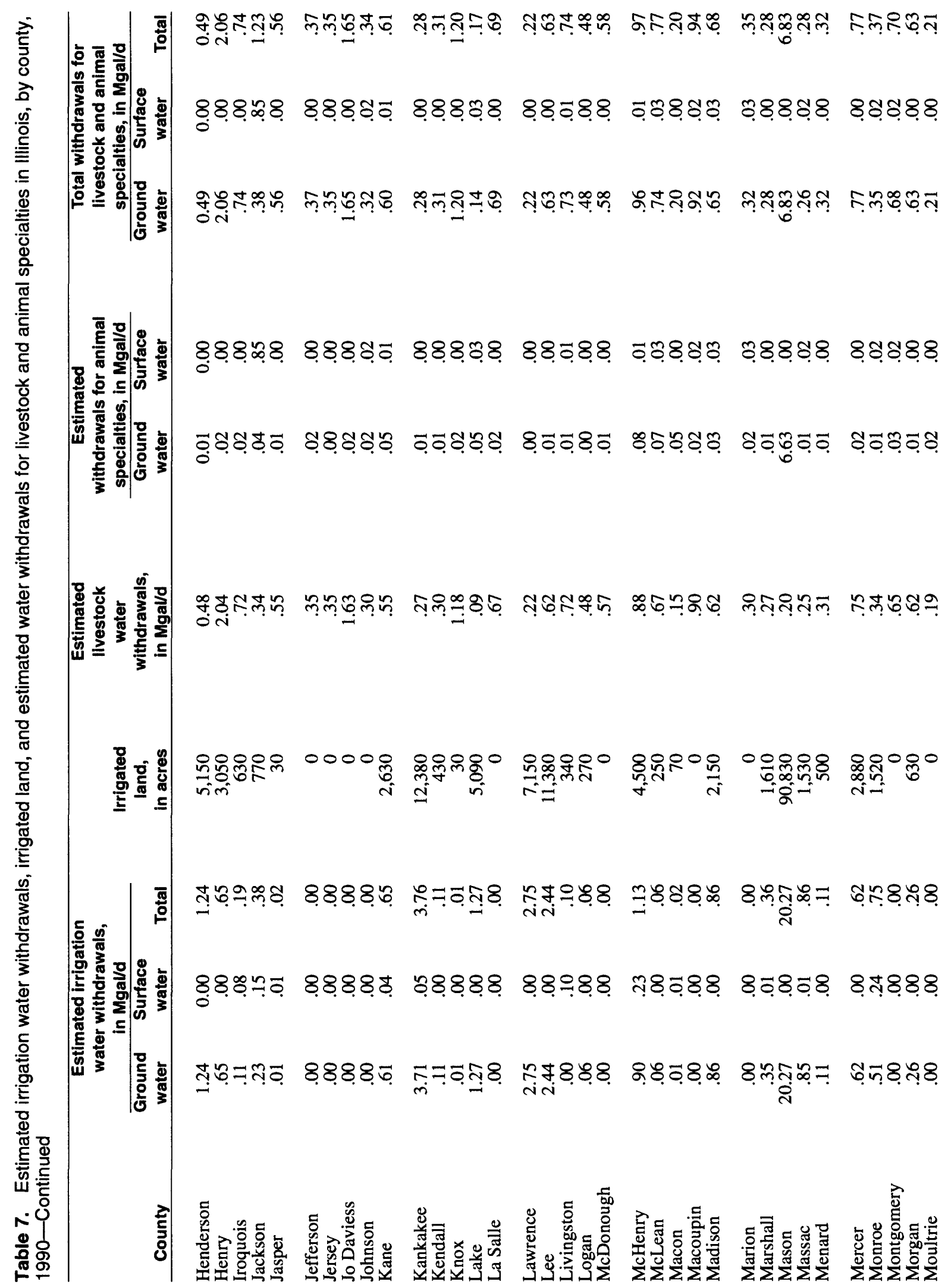




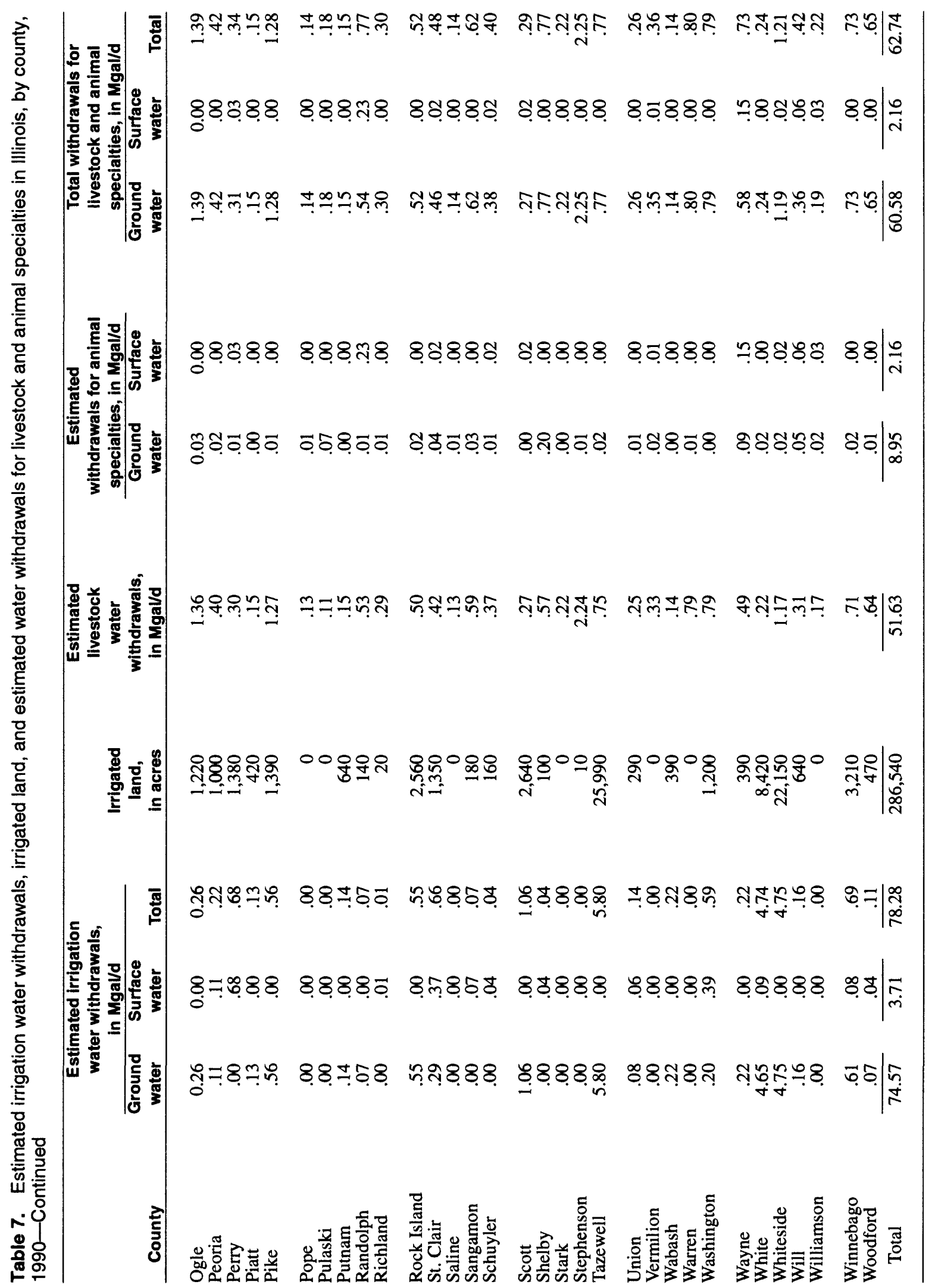




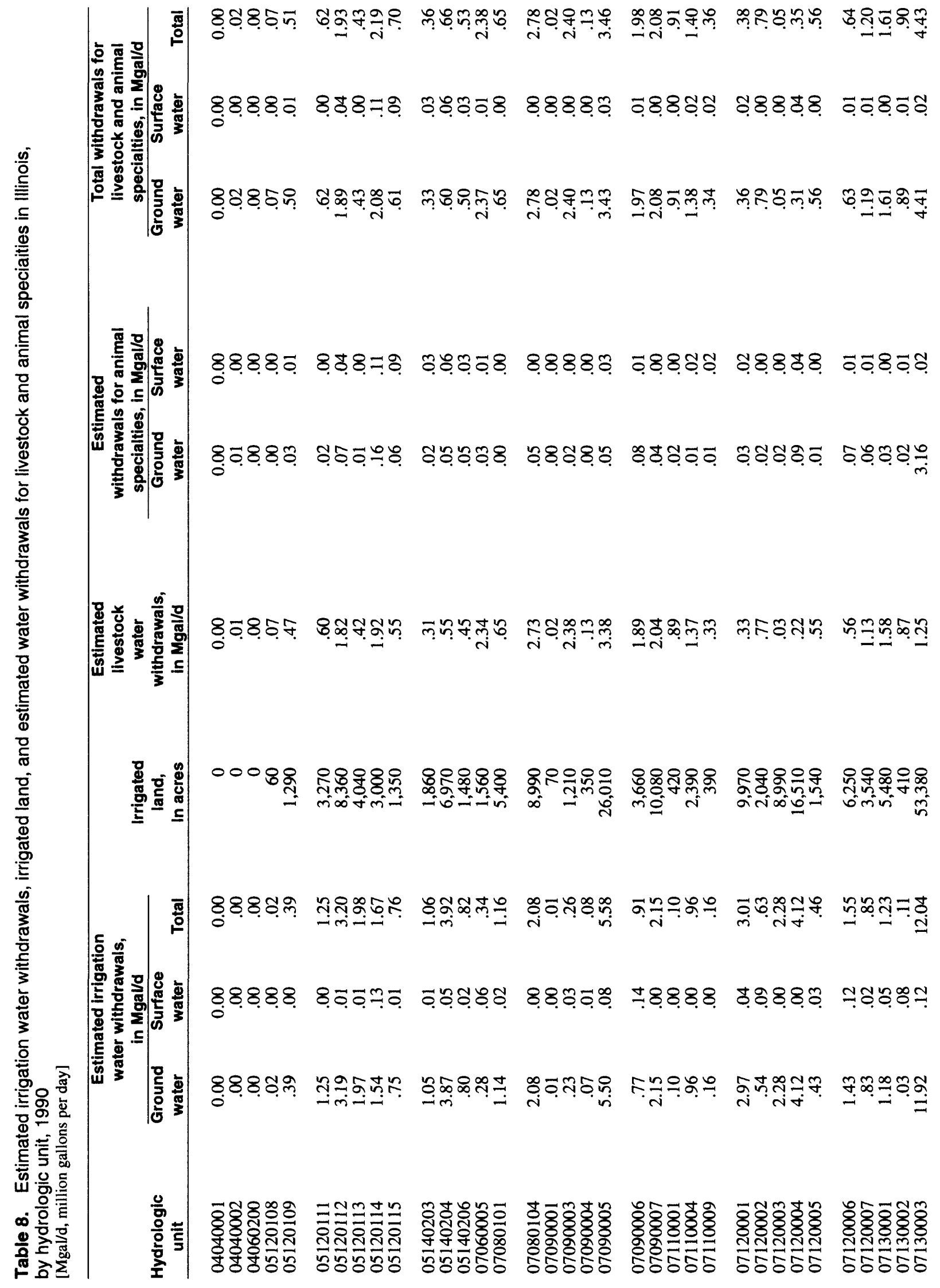




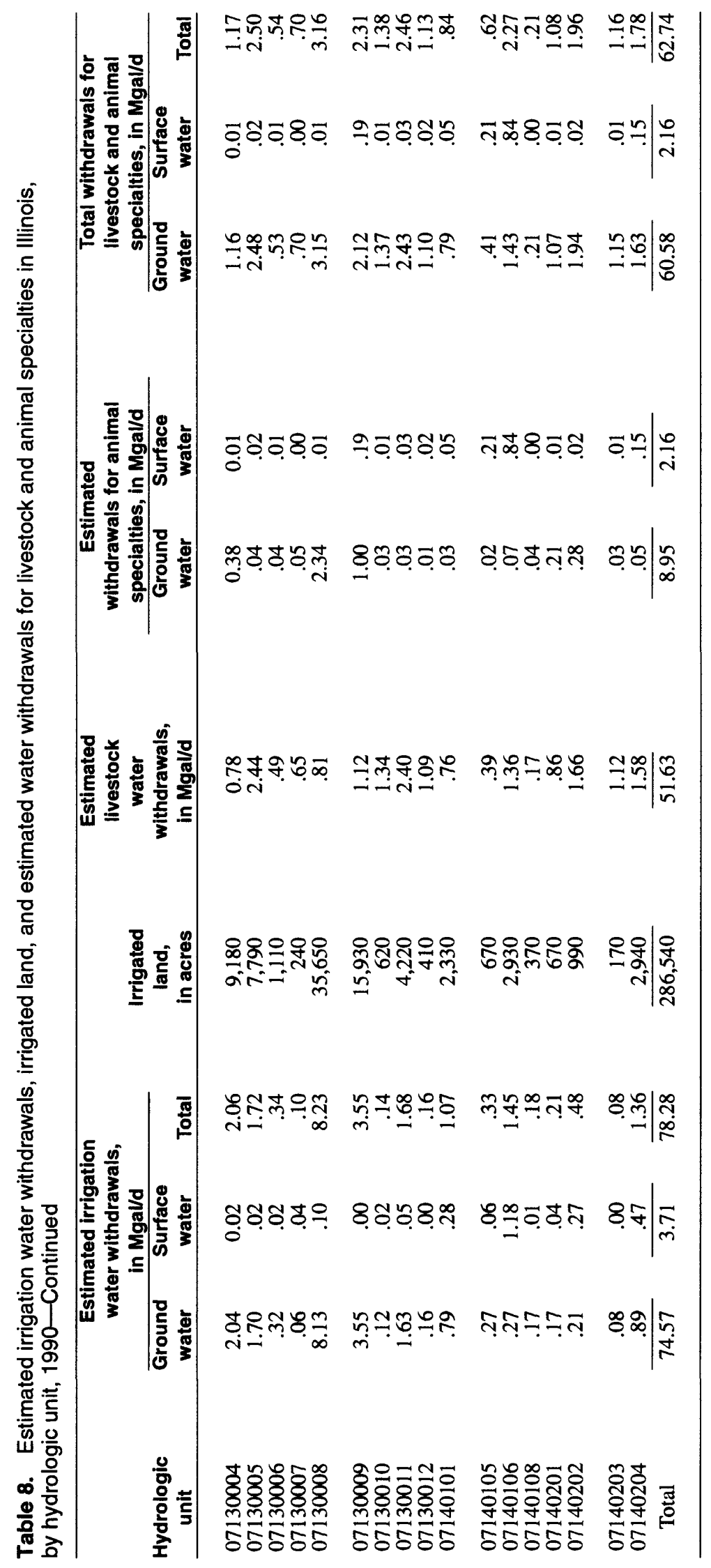


Table 9. Industrial self-supplied withdrawals and deliveries from public-water facilities for industrial use in Illinois, by county, 1990

[All values are in million gallons per day]

\begin{tabular}{|c|c|c|c|c|c|}
\hline County & \multicolumn{3}{|c|}{ Self-suppiied withdrawais } & $\begin{array}{c}\text { Deiiveries } \\
\text { from } \\
\text { pubilc-supply } \\
\text { faciitities }\end{array}$ & $\begin{array}{c}\text { Total } \\
\text { seif-suppiied } \\
\text { withdrawais and } \\
\text { public-suppiy } \\
\text { deiiveries }\end{array}$ \\
\hline $\begin{array}{l}\text { Adams } \\
\text { Alexander } \\
\text { Bond } \\
\text { Boone } \\
\text { Brown }\end{array}$ & $\begin{array}{r}10.28 \\
.01 \\
.00 \\
.07 \\
.00\end{array}$ & $\begin{array}{r}0.00 \\
.00 \\
.00 \\
.00 \\
.00\end{array}$ & $\begin{array}{r}10.28 \\
.01 \\
.00 \\
.07 \\
.00\end{array}$ & $\begin{array}{r}2.06 \\
.39 \\
.06 \\
1.64 \\
.00\end{array}$ & $\begin{array}{r}12.34 \\
.40 \\
.06 \\
1.71 \\
.00\end{array}$ \\
\hline $\begin{array}{l}\text { Bureau } \\
\text { Calhoun } \\
\text { Carroll } \\
\text { Cass } \\
\text { Champaign }\end{array}$ & $\begin{array}{r}.02 \\
.00 \\
1.96 \\
1.70 \\
3.61\end{array}$ & $\begin{array}{l}.00 \\
.00 \\
.00 \\
.00 \\
.00\end{array}$ & $\begin{array}{l}.02 \\
.00 \\
1.96 \\
1.70 \\
3.61\end{array}$ & $\begin{array}{r}.49 \\
.00 \\
.17 \\
.00 \\
2.15\end{array}$ & $\begin{array}{r}.51 \\
.00 \\
2.13 \\
1.70 \\
5.76\end{array}$ \\
\hline $\begin{array}{l}\text { Christian } \\
\text { Clark } \\
\text { Clay } \\
\text { Clinton } \\
\text { Coles }\end{array}$ & $\begin{array}{l}.00 \\
.00 \\
.00 \\
.00 \\
.00\end{array}$ & $\begin{array}{l}.00 \\
.00 \\
.00 \\
.00 \\
.00\end{array}$ & $\begin{array}{l}.00 \\
.00 \\
.00 \\
.00 \\
.00\end{array}$ & $\begin{array}{r}1.36 \\
.00 \\
.22 \\
.01 \\
.04\end{array}$ & $\begin{array}{r}1.36 \\
.00 \\
.22 \\
.01 \\
.04\end{array}$ \\
\hline $\begin{array}{l}\text { Cook } \\
\text { Crawford } \\
\text { Cumberland } \\
\text { De Kalb } \\
\text { De Witt }\end{array}$ & $\begin{array}{r}20.08 \\
.00 \\
.00 \\
.48 \\
.00\end{array}$ & $\begin{array}{r}159.35 \\
4.26 \\
.00 \\
.16 \\
.00\end{array}$ & $\begin{array}{r}179.43 \\
4.26 \\
.00 \\
.64 \\
.00\end{array}$ & $\begin{array}{r}174.05 \\
.49 \\
.00 \\
.43 \\
.00\end{array}$ & $\begin{array}{r}353.48 \\
4.75 \\
.00 \\
1.07 \\
.00\end{array}$ \\
\hline $\begin{array}{l}\text { Douglas } \\
\text { Du Page } \\
\text { Edgar } \\
\text { Edwards } \\
\text { Effingham }\end{array}$ & $\begin{array}{l}.00 \\
.39 \\
.00 \\
.00 \\
.00\end{array}$ & $\begin{array}{l}5.48 \\
.00 \\
.00 \\
.00 \\
.00\end{array}$ & $\begin{array}{r}5.48 \\
.39 \\
.00 \\
.00 \\
.00\end{array}$ & $\begin{array}{r}.01 \\
5.76 \\
.00 \\
.03 \\
.01\end{array}$ & $\begin{array}{r}5.49 \\
6.15 \\
.00 \\
.03 \\
.01\end{array}$ \\
\hline $\begin{array}{l}\text { Fayette } \\
\text { Ford } \\
\text { Franklin } \\
\text { Fulton } \\
\text { Gallatin }\end{array}$ & $\begin{array}{l}.00 \\
.00 \\
.00 \\
.00 \\
.00\end{array}$ & $\begin{array}{l}.00 \\
.00 \\
.00 \\
.00 \\
.00\end{array}$ & $\begin{array}{l}.00 \\
.00 \\
.00 \\
.00 \\
.00\end{array}$ & $\begin{array}{l}.07 \\
.17 \\
.19 \\
.04 \\
.00\end{array}$ & $\begin{array}{l}.07 \\
.17 \\
.19 \\
.04 \\
.00\end{array}$ \\
\hline $\begin{array}{l}\text { Greene } \\
\text { Grundy } \\
\text { Hamilton } \\
\text { Hancock } \\
\text { Hardin }\end{array}$ & $\begin{array}{r}.00 \\
6.24 \\
.00 \\
.00 \\
.00\end{array}$ & $\begin{array}{l}.00 \\
.07 \\
.00 \\
.00 \\
.00\end{array}$ & $\begin{array}{r}.00 \\
6.31 \\
.00 \\
.00 \\
.00\end{array}$ & $\begin{array}{l}.00 \\
.06 \\
.00 \\
.03 \\
.11\end{array}$ & $\begin{array}{r}.00 \\
6.37 \\
.00 \\
.03 \\
.11\end{array}$ \\
\hline $\begin{array}{l}\text { Henderson } \\
\text { Henry } \\
\text { Iroquois } \\
\text { Jackson } \\
\text { Jasper }\end{array}$ & $\begin{array}{l}.00 \\
.03 \\
.07 \\
.00 \\
.00\end{array}$ & $\begin{array}{l}.00 \\
.00 \\
.00 \\
.00 \\
.00\end{array}$ & $\begin{array}{l}.00 \\
.03 \\
.07 \\
.00 \\
.00\end{array}$ & $\begin{array}{r}.00 \\
.21 \\
.03 \\
2.41 \\
.00\end{array}$ & $\begin{array}{r}.00 \\
.24 \\
.10 \\
2.41 \\
.00\end{array}$ \\
\hline $\begin{array}{l}\text { Jefferson } \\
\text { Jersey } \\
\text { Jo Daviess } \\
\text { Johnson } \\
\text { Kane }\end{array}$ & $\begin{array}{r}.00 \\
.00 \\
1.72 \\
.00 \\
1.52\end{array}$ & $\begin{array}{l}.00 \\
.00 \\
.00 \\
.00 \\
.00\end{array}$ & $\begin{array}{r}.00 \\
.00 \\
1.72 \\
.00 \\
1.52\end{array}$ & $\begin{array}{r}.02 \\
.00 \\
.65 \\
.00 \\
5.20\end{array}$ & $\begin{array}{r}.02 \\
.00 \\
2.37 \\
.00 \\
6.72\end{array}$ \\
\hline $\begin{array}{l}\text { Kankakee } \\
\text { Kendall } \\
\text { Knox } \\
\text { Lake } \\
\text { La Salle }\end{array}$ & $\begin{array}{r}.12 \\
.32 \\
.00 \\
.69 \\
3.25\end{array}$ & $\begin{array}{r}.00 \\
.00 \\
.00 \\
11.61 \\
3.93\end{array}$ & $\begin{array}{r}.12 \\
.32 \\
.00 \\
12.30 \\
7.18\end{array}$ & $\begin{array}{r}4.13 \\
.23 \\
2.83 \\
3.35 \\
1.30\end{array}$ & $\begin{array}{r}4.25 \\
.55 \\
2.83 \\
15.65 \\
8.48\end{array}$ \\
\hline
\end{tabular}


Table 9. Industrial self-supplied withdrawals and deliveries from public-water facilities for industrial use in Illinois, by county, 1990-Continued

\begin{tabular}{|c|c|c|c|c|c|}
\hline \multirow[b]{2}{*}{ County } & \multicolumn{3}{|c|}{ Seif-supplied withdrawals } & \multirow{2}{*}{$\begin{array}{c}\text { Deliveries } \\
\text { from } \\
\text { public-suppiy } \\
\text { facilities }\end{array}$} & \multirow{2}{*}{$\begin{array}{c}\text { Total } \\
\text { self-supplied } \\
\text { withdrawals and } \\
\text { public-supply } \\
\text { deliveries }\end{array}$} \\
\hline & $\begin{array}{c}\text { Ground } \\
\text { water }\end{array}$ & $\begin{array}{c}\text { Surface } \\
\text { water }\end{array}$ & Totai & & \\
\hline $\begin{array}{l}\text { Lawrence } \\
\text { Lee } \\
\text { Livingston } \\
\text { Logan } \\
\text { McDonough }\end{array}$ & $\begin{array}{l}0.00 \\
.03 \\
.09 \\
.00 \\
.02\end{array}$ & $\begin{array}{r}0.00 \\
.02 \\
.00 \\
.00 \\
.00\end{array}$ & $\begin{array}{r}0.00 \\
.05 \\
.09 \\
.00 \\
.02\end{array}$ & $\begin{array}{r}0.03 \\
.65 \\
.34 \\
.39 \\
.06\end{array}$ & $\begin{array}{r}0.03 \\
.70 \\
.43 \\
.39 \\
.08\end{array}$ \\
\hline $\begin{array}{l}\text { McHenry } \\
\text { McLean } \\
\text { Macon } \\
\text { Macoupin } \\
\text { Madison }\end{array}$ & $\begin{array}{r}2.44 \\
.03 \\
.00 \\
.00 \\
34.08\end{array}$ & $\begin{array}{r}1.21 \\
.00 \\
8.50 \\
.00 \\
22.21\end{array}$ & $\begin{array}{r}3.65 \\
.03 \\
8.50 \\
.00 \\
56.29\end{array}$ & $\begin{array}{r}3.07 \\
.93 \\
.00 \\
.14 \\
20.83\end{array}$ & $\begin{array}{r}6.72 \\
.96 \\
8.50 \\
.14 \\
77.12\end{array}$ \\
\hline $\begin{array}{l}\text { Marion } \\
\text { Marshall } \\
\text { Mason } \\
\text { Massac } \\
\text { Menard }\end{array}$ & $\begin{array}{r}.00 \\
1.24 \\
.00 \\
4.87 \\
.00\end{array}$ & $\begin{array}{l}.00 \\
.00 \\
.00 \\
.00 \\
.00\end{array}$ & $\begin{array}{r}.00 \\
1.24 \\
.00 \\
4.87 \\
.00\end{array}$ & $\begin{array}{l}.36 \\
.00 \\
.04 \\
.00 \\
.00\end{array}$ & $\begin{array}{r}.36 \\
1.24 \\
.04 \\
4.87 \\
.00\end{array}$ \\
\hline $\begin{array}{l}\text { Mercer } \\
\text { Monroe } \\
\text { Montgomery } \\
\text { Morgan } \\
\text { Moultrie }\end{array}$ & $\begin{array}{r}.00 \\
.00 \\
.00 \\
3.91 \\
.00\end{array}$ & $\begin{array}{l}.00 \\
.00 \\
.44 \\
.00 \\
.00\end{array}$ & $\begin{array}{r}.00 \\
.00 \\
.44 \\
3.91 \\
.00\end{array}$ & $\begin{array}{l}.00 \\
.11 \\
.10 \\
.02 \\
.00\end{array}$ & $\begin{array}{r}.00 \\
.11 \\
.54 \\
3.93 \\
.00\end{array}$ \\
\hline $\begin{array}{l}\text { Ogle } \\
\text { Peoria } \\
\text { Perry } \\
\text { Piatt } \\
\text { Pike }\end{array}$ & $\begin{array}{r}.68 \\
15.37 \\
.00 \\
.74 \\
.00\end{array}$ & $\begin{array}{r}.00 \\
11.83 \\
.61 \\
.00 \\
.00\end{array}$ & $\begin{array}{r}.68 \\
27.20 \\
.61 \\
.74 \\
.00\end{array}$ & $\begin{array}{l}2.57 \\
1.82 \\
.00 \\
.02 \\
.01\end{array}$ & $\begin{array}{r}3.25 \\
29.02 \\
.61 \\
.76 \\
.01\end{array}$ \\
\hline $\begin{array}{l}\text { Pope } \\
\text { Pulaski } \\
\text { Putnam } \\
\text { Randolph } \\
\text { Richland }\end{array}$ & $\begin{array}{l}.00 \\
.00 \\
.10 \\
.00 \\
.00\end{array}$ & $\begin{array}{r}.00 \\
.00 \\
4.30 \\
.00 \\
.00\end{array}$ & $\begin{array}{r}.00 \\
.00 \\
4.40 \\
.00 \\
.00\end{array}$ & $\begin{array}{l}.00 \\
.02 \\
.09 \\
.16 \\
.60\end{array}$ & $\begin{array}{r}.00 \\
.02 \\
4.49 \\
.16 \\
.60\end{array}$ \\
\hline $\begin{array}{l}\text { Rock Island } \\
\text { St. Clair } \\
\text { Saline } \\
\text { Sangamon } \\
\text { Schuyler }\end{array}$ & $\begin{array}{r}12.58 \\
2.73 \\
.00 \\
.00 \\
.00\end{array}$ & $\begin{array}{r}36.41 \\
.00 \\
.00 \\
.00 \\
.00\end{array}$ & $\begin{array}{r}48.99 \\
2.73 \\
.00 \\
.00 \\
.00\end{array}$ & $\begin{array}{r}2.45 \\
8.19 \\
.39 \\
.04 \\
.03\end{array}$ & $\begin{array}{r}51.44 \\
10.92 \\
.39 \\
.04 \\
.03\end{array}$ \\
\hline $\begin{array}{l}\text { Scott } \\
\text { Shelby } \\
\text { Stark } \\
\text { Stephenson } \\
\text { Tazewell }\end{array}$ & $\begin{array}{r}.00 \\
.29 \\
.00 \\
1.82 \\
6.50\end{array}$ & $\begin{array}{r}.00 \\
.00 \\
.00 \\
.00 \\
17.44\end{array}$ & $\begin{array}{r}.00 \\
.29 \\
.00 \\
1.82 \\
23.94\end{array}$ & $\begin{array}{l}.00 \\
.00 \\
.00 \\
.01 \\
.97\end{array}$ & $\begin{array}{r}.00 \\
.29 \\
.00 \\
1.83 \\
24.91\end{array}$ \\
\hline $\begin{array}{l}\text { Union } \\
\text { Vermilion } \\
\text { Wabash } \\
\text { Warren } \\
\text { Washington }\end{array}$ & $\begin{array}{r}.00 \\
2.96 \\
.00 \\
.00 \\
.00\end{array}$ & $\begin{array}{l}.00 \\
.00 \\
.00 \\
.00 \\
.00\end{array}$ & $\begin{array}{r}.00 \\
2.96 \\
.00 \\
.00 \\
.00\end{array}$ & $\begin{array}{r}.06 \\
3.35 \\
.15 \\
.07 \\
.12\end{array}$ & $\begin{array}{r}.06 \\
6.31 \\
.15 \\
.07 \\
.12\end{array}$ \\
\hline $\begin{array}{l}\text { Wayne } \\
\text { White } \\
\text { Whiteside } \\
\text { Will } \\
\text { Williamson }\end{array}$ & $\begin{array}{r}.00 \\
.00 \\
3.62 \\
4.53 \\
.00\end{array}$ & $\begin{array}{r}.00 \\
.00 \\
4.03 \\
17.19 \\
.40\end{array}$ & $\begin{array}{r}.00 \\
.00 \\
7.65 \\
21.72 \\
.40\end{array}$ & $\begin{array}{r}.00 \\
.00 \\
.79 \\
2.10 \\
.07\end{array}$ & $\begin{array}{r}.00 \\
.00 \\
8.44 \\
23.82 \\
.47\end{array}$ \\
\hline $\begin{array}{l}\text { Winnebago } \\
\text { Woodford }\end{array}$ & $\begin{array}{r}3.59 \\
.01 \\
\end{array}$ & $\begin{array}{l}.00 \\
.00 \\
\end{array}$ & $\begin{array}{r}3.59 \\
.01 \\
\end{array}$ & $\begin{array}{r}1.92 \\
.01 \\
\end{array}$ & $\begin{array}{r}5.51 \\
.02 \\
\end{array}$ \\
\hline Total & 154.79 & 309.45 & 464.24 & 263.48 & 727.72 \\
\hline
\end{tabular}


Table 10. Industrial self-supplied withdrawals and deliveries from public-water facilities for industrial use in Illinois, by hydrologic unit, 1990

[All values are in million gallons per day]

\begin{tabular}{|c|c|c|c|c|c|}
\hline \multirow[b]{2}{*}{$\begin{array}{c}\text { Hydrologic } \\
\text { unit }\end{array}$} & \multicolumn{3}{|c|}{ Seif-suppiied withdrawals } & \multirow{2}{*}{$\begin{array}{c}\text { Deliveries } \\
\text { from } \\
\text { public-supply } \\
\text { facilities }\end{array}$} & \multirow{2}{*}{$\begin{array}{c}\text { Total self- } \\
\text { supplied } \\
\text { withdrawals } \\
\text { and } \\
\text { public-supply } \\
\text { deliveries } \\
\end{array}$} \\
\hline & $\begin{array}{c}\text { Ground } \\
\text { water }\end{array}$ & $\begin{array}{c}\text { Surface } \\
\text { water }\end{array}$ & Total & & \\
\hline 04040001 & 0.00 & 35.78 & 35.78 & 3.21 & 38.99 \\
\hline 04040002 & .02 & 69.71 & 69.73 & 3.37 & 73.10 \\
\hline 04060200 & .00 & 11.61 & 11.61 & .00 & 11.61 \\
\hline 05120108 & .00 & .00 & .00 & .50 & .50 \\
\hline 05120109 & 2.98 & .00 & 2.98 & 3.61 & 6.59 \\
\hline 05120111 & .00 & 4.26 & 4.26 & .17 & 4.43 \\
\hline 05120112 & .00 & .00 & .00 & .76 & .76 \\
\hline 05120113 & .00 & .00 & .00 & .26 & .26 \\
\hline 05120114 & .00 & .00 & .00 & .67 & .67 \\
\hline 05120115 & .00 & .00 & .00 & .15 & .15 \\
\hline 05140203 & .00 & .00 & .00 & .09 & .09 \\
\hline 05140204 & .00 & .00 & .00 & .44 & .44 \\
\hline 05140206 & 4.87 & .00 & 4.87 & .02 & 4.89 \\
\hline 07060005 & 3.67 & .00 & 3.67 & .73 & 4.40 \\
\hline 07080101 & 10.79 & 36.41 & 47.20 & 2.57 & 49.77 \\
\hline 07080104 & .00 & .00 & .00 & .61 & .61 \\
\hline 07090001 & .36 & .00 & .36 & .08 & .44 \\
\hline 07090003 & 1.82 & .00 & 1.82 & .73 & 2.55 \\
\hline 07090004 & .00 & .00 & .00 & .21 & .21 \\
\hline 07090005 & 8.73 & 4.05 & 12.78 & 4.26 & 17.04 \\
\hline 07090006 & 1.56 & 1.37 & 2.93 & 4.93 & 7.86 \\
\hline 07090007 & .03 & .00 & .03 & .68 & .71 \\
\hline 07110001 & 9.53 & .00 & 9.53 & 1.09 & 10.62 \\
\hline 07110004 & .00 & .00 & .00 & .46 & .46 \\
\hline 07110009 & 12.63 & 4.41 & 17.04 & .71 & 17.75 \\
\hline 07120001 & .12 & .00 & .12 & 4.01 & 4.13 \\
\hline 07120002 & .07 & .00 & .07 & .80 & .87 \\
\hline 07120003 & 18.43 & 49.14 & 67.57 & 64.65 & 132.22 \\
\hline 07120004 & 7.20 & 21.92 & 29.12 & 101.45 & 130.57 \\
\hline 07120005 & 8.54 & 1.47 & 10.01 & .88 & 10.89 \\
\hline 07120006 & 2.16 & .00 & 2.16 & 13.20 & 15.36 \\
\hline 07120007 & 2.06 & .00 & 2.06 & 4.71 & 6.77 \\
\hline 07130001 & 5.20 & 11.11 & 16.31 & 1.21 & 17.52 \\
\hline 07130002 & .09 & .00 & .09 & .61 & .70 \\
\hline 07130003 & 21.08 & 24.98 & 46.06 & 1.65 & 47.71 \\
\hline 07130004 & .09 & .00 & .09 & .35 & .44 \\
\hline 07130005 & .00 & .00 & .00 & 3.03 & 3.03 \\
\hline 07130006 & .74 & 8.50 & 9.24 & .93 & 10.17 \\
\hline 07130007 & .00 & .00 & .00 & 1.04 & 1.04 \\
\hline 07130008 & .00 & .00 & .00 & .11 & .11 \\
\hline 07130009 & .03 & .00 & .03 & 1.14 & 1.17 \\
\hline 07130010 & .02 & .00 & .02 & .22 & .24 \\
\hline 07130011 & 3.91 & .00 & 3.91 & .41 & 4.32 \\
\hline 07130012 & .00 & .00 & .00 & .14 & .14 \\
\hline 07140101 & 24.17 & 17.80 & 41.97 & 1.69 & 43.66 \\
\hline 07140105 & .00 & .00 & .00 & .44 & .44 \\
\hline 07140106 & .00 & 1.01 & 1.01 & 2.34 & 3.35 \\
\hline 07140108 & .01 & .00 & .01 & .42 & .43 \\
\hline 07140201 & 3.88 & 5.48 & 9.36 & .40 & 9.76 \\
\hline 07140202 & .00 & .00 & .00 & .35 & .35 \\
\hline 07140203 & & & .44 & & .57 \\
\hline 07140204 & .00 & .00 & .00 & 26.86 & 26.86 \\
\hline Total & $\overline{154.79}$ & 309.45 & $\overline{464.24}$ & $\overline{263.48}$ & $\overline{727.72}$ \\
\hline
\end{tabular}


Table 11. Mining withdrawals and consumptive use in Illinois, by county, 1990 [All values are in million gallons per day]

\begin{tabular}{|c|c|c|c|c|c|c|c|c|c|c|}
\hline \multirow[b]{3}{*}{ County } & \multicolumn{7}{|c|}{ Withdrawals } & & & \\
\hline & \multicolumn{3}{|c|}{ Ground water } & \multirow{2}{*}{$\begin{array}{c}\text { Surface } \\
\text { water }\end{array}$} & \multicolumn{3}{|c|}{ Total } & \multicolumn{3}{|c|}{ Consumptive use } \\
\hline & Fresh & Saline & Total & & Fresh & Saline & Total & Fresh & Saline & Total \\
\hline Adams & 0.00 & 0.00 & 0.00 & 0.00 & 0.00 & 0.00 & 0.00 & 0.00 & 0.00 & 0.00 \\
\hline Alexander & .00 & .00 & .00 & .00 & .00 & .00 & .00 & .00 & .00 & .00 \\
\hline Bond & .00 & .00 & .00 & .00 & .00 & .00 & .00 & .00 & .00 & .00 \\
\hline Boone & .00 & .00 & .00 & .00 & .00 & .00 & .00 & .00 & .00 & .00 \\
\hline Brown & .00 & .00 & .00 & .00 & .00 & .00 & .00 & .00 & .00 & .00 \\
\hline Bureau & .00 & .00 & .00 & .00 & .00 & .00 & .00 & .00 & .00 & .00 \\
\hline Calhoun & .00 & .00 & .00 & .00 & .00 & .00 & .00 & .00 & .00 & .00 \\
\hline Carroll & .00 & .00 & .00 & .00 & .00 & .00 & .00 & .00 & .00 & .00 \\
\hline Cass & .00 & .00 & .00 & .00 & .00 & .00 & .00 & .00 & .00 & .00 \\
\hline Champaign & .00 & .00 & .00 & 5.23 & 5.23 & .00 & 5.23 & .78 & .00 & .78 \\
\hline Christian & .01 & .46 & .47 & .22 & .23 & .46 & .69 & .11 & .46 & .57 \\
\hline Clark & .10 & .11 & .21 & .00 & .10 & .11 & .21 & .05 & .11 & .16 \\
\hline Clay & .00 & .72 & .72 & .00 & .00 & .72 & .72 & .00 & .72 & .72 \\
\hline Clinton & .37 & .31 & .68 & 1.39 & 1.76 & .31 & 2.07 & .77 & .31 & 1.08 \\
\hline Coles & .00 & .12 & .12 & .01 & .01 & .12 & .13 & .00 & .12 & .12 \\
\hline Cook & .00 & .00 & .00 & .55 & .55 & .00 & .55 & .08 & .00 & .08 \\
\hline Crawford & .00 & 3.60 & 3.60 & .00 & .00 & 3.60 & 3.60 & .00 & 3.60 & 3.60 \\
\hline Cumberland & .09 & .11 & .20 & .00 & .09 & .11 & .20 & .04 & .11 & .15 \\
\hline De Kalb & .00 & .00 & .00 & 2.77 & 2.77 & .00 & 2.77 & .42 & .00 & .42 \\
\hline De Witt & .00 & .00 & .00 & .00 & .00 & .00 & .00 & .00 & .00 & .00 \\
\hline Douglas & .00 & .00 & .00 & .24 & .24 & .00 & .24 & .12 & .00 & .12 \\
\hline Du Page & .06 & .00 & .06 & .00 & .06 & .00 & .06 & .01 & .00 & .01 \\
\hline Edgar & .00 & .09 & .09 & .00 & .00 & .09 & .09 & .00 & .09 & .09 \\
\hline Edwards & .00 & .49 & .49 & .00 & .00 & .49 & .49 & .00 & .49 & .49 \\
\hline Effingham & .00 & .22 & .22 & .00 & .00 & .22 & .22 & .00 & .22 & .22 \\
\hline Fayette & .00 & 1.28 & 1.28 & .00 & .00 & 1.28 & 1.28 & .00 & 1.28 & 1.28 \\
\hline Ford & .00 & .00 & .00 & .03 & .03 & .00 & .03 & .01 & .00 & .01 \\
\hline Franklin & .02 & .23 & .25 & 2.47 & 2.49 & .23 & 2.72 & 1.21 & .23 & 1.44 \\
\hline Fulton & .29 & .00 & .29 & .73 & 1.02 & .00 & 1.02 & .41 & .00 & .41 \\
\hline Gallatin & 1.54 & .27 & 1.81 & 1.16 & 2.70 & .27 & 2.97 & 1.32 & .27 & 1.59 \\
\hline Greene & .00 & .00 & .00 & .00 & .00 & .00 & .00 & .00 & .00 & .00 \\
\hline Grundy & .00 & .00 & .00 & .00 & .00 & .00 & .00 & .00 & .00 & .00 \\
\hline Hamilton & .00 & .51 & .51 & .32 & .32 & .51 & .83 & .16 & .51 & .67 \\
\hline Hancock & .00 & .00 & .00 & .00 & .00 & .00 & .00 & .00 & .00 & .00 \\
\hline Hardin & 1.16 & .00 & 1.16 & .00 & 1.16 & .00 & 1.16 & .17 & .00 & .17 \\
\hline Henderson & .00 & .00 & .00 & .00 & .00 & .00 & .00 & .00 & .00 & .00 \\
\hline Henry & .00 & .00 & .00 & .00 & .00 & .00 & .00 & .00 & .00 & .00 \\
\hline Iroquois & .00 & .00 & .00 & .00 & .00 & .00 & .00 & .00 & .00 & .00 \\
\hline Jackson & .00 & .00 & .00 & .72 & .72 & .00 & .72 & .35 & .00 & .35 \\
\hline Jasper & .00 & 1.10 & 1.10 & .00 & .00 & 1.10 & 1.10 & .00 & 1.10 & 1.10 \\
\hline Jefferson & .00 & .77 & .77 & .83 & .83 & .77 & 1.60 & .41 & .77 & 1.18 \\
\hline Jersey & .00 & .00 & .00 & .00 & .00 & .00 & .00 & .00 & .00 & .00 \\
\hline Jo Daviess & .00 & .00 & .00 & .00 & .00 & .00 & .00 & .00 & .00 & .00 \\
\hline Johnson & .00 & .00 & .00 & .00 & .00 & .00 & .00 & .00 & .00 & .00 \\
\hline Kane & .00 & .00 & .00 & .79 & .79 & .00 & .79 & .12 & .00 & .12 \\
\hline Kankakee & .79 & .00 & .79 & .00 & .79 & .00 & .79 & .12 & .00 & .12 \\
\hline Kendall & .00 & .00 & .00 & .00 & .00 & .00 & .00 & .00 & .00 & .00 \\
\hline Knox & .00 & .00 & .00 & .00 & .00 & .00 & .00 & .00 & .00 & .00 \\
\hline Lake & .51 & .00 & .51 & .54 & 1.05 & .00 & 1.05 & .16 & .00 & .16 \\
\hline La Salle & .15 & .00 & .15 & 20.75 & 20.90 & .00 & 20.90 & 3.14 & .00 & 3.14 \\
\hline Lawrence & .40 & 7.22 & 7.62 & .00 & .40 & 7.22 & 7.62 & .20 & 7.22 & 7.42 \\
\hline Lee & .00 & .00 & .00 & .00 & .00 & .00 & .00 & .00 & .00 & .00 \\
\hline Livingston & .00 & .00 & .00 & .00 & .00 & .00 & .00 & .00 & .00 & .00 \\
\hline Logan & .23 & .00 & .23 & .11 & .34 & .00 & .34 & .17 & .00 & .17 \\
\hline McDonough & .00 & .00 & .00 & .58 & .58 & .00 & .58 & .28 & .00 & .28 \\
\hline
\end{tabular}


Table 11. Mining withdrawals and consumptive use in Illinois, by county, 1990-Continued

\begin{tabular}{|c|c|c|c|c|c|c|c|c|c|c|}
\hline \multirow[b]{3}{*}{ County } & \multicolumn{7}{|c|}{ Withdrawals } & & & \\
\hline & \multicolumn{3}{|c|}{ Ground water } & \multirow{2}{*}{$\begin{array}{c}\text { Surface } \\
\text { water }\end{array}$} & \multicolumn{3}{|c|}{ Total } & \multicolumn{3}{|c|}{ Consumptive use } \\
\hline & Fresh & Saline & Total & & Fresh & Saline & Total & Fresh & Saline & Total \\
\hline McHenry & .00 & .00 & .00 & 2.59 & 2.59 & .00 & 2.59 & .39 & .00 & .39 \\
\hline McLean & .00 & .00 & .00 & .00 & .00 & .00 & .00 & .00 & .00 & .00 \\
\hline Macon & .00 & .00 & .00 & .00 & .00 & .00 & .00 & .00 & .00 & .00 \\
\hline Macoupin & .00 & .00 & .00 & 1.65 & 1.65 & .00 & 1.65 & .81 & .00 & .81 \\
\hline Madison & .00 & .09 & .09 & .00 & .00 & .09 & .09 & .00 & .09 & .09 \\
\hline Marion & .00 & .65 & .65 & .00 & .00 & .65 & .65 & .00 & .65 & .65 \\
\hline Marshall & .00 & .00 & .00 & .00 & .00 & .00 & .00 & .00 & .00 & .00 \\
\hline Mason & .00 & .00 & .00 & .00 & .00 & .00 & .00 & .00 & .00 & .00 \\
\hline Massac & .00 & .00 & .00 & .00 & .00 & .00 & .00 & .00 & .00 & .00 \\
\hline Menard & .00 & .00 & .00 & .00 & .00 & .00 & .00 & .00 & .00 & .00 \\
\hline Mercer & .00 & .00 & .00 & .00 & .00 & .00 & .00 & .00 & .00 & .00 \\
\hline Monroe & .00 & .00 & .00 & .00 & .00 & .00 & .00 & .00 & .00 & .00 \\
\hline Montgomery & .00 & .00 & .00 & .14 & .14 & .00 & .14 & .07 & .00 & .07 \\
\hline Morgan & .00 & .00 & .00 & .00 & .00 & .00 & .00 & .00 & .00 & .00 \\
\hline Moultrie & .00 & .00 & .00 & .00 & .00 & .00 & .00 & .00 & .00 & .00 \\
\hline Ogle & .35 & .00 & .35 & .00 & .35 & .00 & .35 & .05 & .00 & .05 \\
\hline Peoria & .00 & .00 & .00 & .00 & .00 & .00 & .00 & .00 & .00 & .00 \\
\hline Perry & 1.28 & .01 & 1.29 & 6.57 & 7.85 & .01 & 7.86 & 3.85 & .01 & 3.86 \\
\hline Piatt & .00 & .00 & .00 & .00 & .00 & .00 & .00 & .00 & .00 & .00 \\
\hline Pike & .00 & .00 & .00 & .00 & .00 & .00 & .00 & .00 & .00 & .00 \\
\hline Pope & .00 & .00 & .00 & .00 & .00 & .00 & .00 & .00 & .00 & .00 \\
\hline Pulaski & .00 & .00 & .00 & .00 & .00 & .00 & .00 & .00 & .00 & .00 \\
\hline Putnam & .00 & .00 & .00 & .00 & .00 & .00 & .00 & .00 & .00 & .00 \\
\hline Randolph & .00 & .00 & .00 & .67 & .67 & .00 & .67 & .33 & .00 & .33 \\
\hline Richland & .00 & .91 & .91 & .00 & .00 & .91 & .91 & .00 & .91 & .91 \\
\hline Rock Island & .00 & .00 & .00 & .34 & .34 & .00 & .34 & .04 & .00 & .04 \\
\hline St. Clair & .00 & .00 & .00 & 2.19 & 2.19 & .00 & 2.19 & 1.07 & .00 & 1.07 \\
\hline Saline & .00 & .35 & .35 & 3.78 & 3.78 & .35 & 4.13 & 1.85 & .35 & 2.20 \\
\hline Sangamon & .00 & .00 & .00 & 1.02 & 1.02 & .00 & 1.02 & .15 & .00 & .15 \\
\hline Schuyler & .00 & .00 & .00 & .00 & .00 & .00 & .00 & .00 & .00 & .00 \\
\hline Scott & .00 & .00 & .00 & .00 & .00 & .00 & .00 & .00 & .00 & .00 \\
\hline Shelby & .00 & .04 & .04 & .00 & .00 & .04 & .04 & .00 & .04 & .04 \\
\hline Stark & .00 & .00 & .00 & .00 & .00 & .00 & .00 & .00 & .00 & .00 \\
\hline Stephenson & .00 & .00 & .00 & .00 & .00 & .00 & .00 & .00 & .00 & .00 \\
\hline Tazewell & .00 & .00 & .00 & .00 & .00 & .00 & .00 & .00 & .00 & .00 \\
\hline Union & .00 & .00 & .00 & .00 & .00 & .00 & .00 & .00 & .00 & .00 \\
\hline Vermilion & .00 & .00 & .00 & .00 & .00 & .00 & .00 & .00 & .00 & .00 \\
\hline Wabash & .11 & 1.23 & 1.34 & .00 & .11 & 1.23 & 1.34 & .05 & 1.23 & 1.28 \\
\hline Warren & .00 & .00 & .00 & .00 & .00 & .00 & .00 & .00 & .00 & .00 \\
\hline Washington & .00 & .35 & .35 & .00 & .00 & .35 & .35 & .00 & .35 & .35 \\
\hline Wayne & .00 & 1.71 & 1.71 & .00 & .00 & 1.71 & 1.71 & .00 & 1.71 & 1.71 \\
\hline White & .09 & 2.49 & 2.58 & .00 & .09 & 2.49 & 2.58 & .04 & 2.49 & 2.53 \\
\hline Whiteside & .00 & .00 & .00 & .00 & .00 & .00 & .00 & .00 & .00 & .00 \\
\hline Will & .00 & .00 & .00 & .00 & .00 & .00 & .00 & .00 & .00 & .00 \\
\hline Williamson & .00 & .03 & .03 & 2.10 & 2.10 & .03 & 2.13 & 1.03 & .03 & 1.06 \\
\hline Winnebago & .00 & .00 & .00 & .74 & .74 & .00 & .74 & .11 & .00 & .11 \\
\hline Woodford & .00 & .00 & .00 & .00 & .00 & .00 & .00 & .00 & .00 & .00 \\
\hline Total & 7.55 & $\overline{25.47}$ & $\overline{33.02}$ & 61.23 & $\overline{68.78}$ & $\overline{25.47}$ & $\overline{94.25}$ & $\overline{20.45}$ & $\overline{25.47}$ & $\overline{45.92}$ \\
\hline
\end{tabular}


Table 12. Mining withdrawals and consumptive use in Illinois, by hydrologic unit, 1990 [All vahes are in million gallons per day]

\begin{tabular}{|c|c|c|c|c|c|c|c|c|c|c|}
\hline \multirow{3}{*}{$\begin{array}{c}\text { Hydrologic } \\
\text { unit }\end{array}$} & \multicolumn{7}{|c|}{ Withdrawals } & \multirow{2}{*}{\multicolumn{3}{|c|}{ Consumptive use }} \\
\hline & \multicolumn{3}{|c|}{ Ground water } & \multirow{2}{*}{$\begin{array}{l}\text { Surface } \\
\text { water }\end{array}$} & \multicolumn{3}{|c|}{ Total } & & & \\
\hline & Fresh & Saline & Totai & & Fresh & Saline & Total & Fresh & Sailine & Total \\
\hline 04040001 & 0.00 & 0.00 & 0.00 & 0.02 & 0.02 & 0.00 & 0.02 & 0.00 & 0.00 & 0.00 \\
\hline 04040002 & .07 & .00 & .07 & .09 & .16 & .00 & .16 & .02 & .00 & .02 \\
\hline 04060200 & .00 & .00 & .00 & .00 & .00 & .00 & .00 & .00 & .00 & .00 \\
\hline 05120108 & .00 & .00 & .00 & .12 & .12 & .00 & .12 & .02 & .00 & .02 \\
\hline 05120109 & .00 & .00 & .00 & 2.32 & 2.32 & .00 & 2.32 & .34 & .00 & .34 \\
\hline 05120111 & .00 & .05 & .05 & .00 & .00 & .05 & .05 & .00 & .05 & .05 \\
\hline 05120112 & .59 & 10.66 & 11.25 & .83 & 1.42 & 10.66 & 12.08 & .47 & 10.66 & 11.13 \\
\hline 05120113 & .32 & 2.55 & 2.87 & .15 & .47 & 2.55 & 3.02 & .23 & 2.55 & 2.78 \\
\hline 05120114 & .03 & 5.32 & 5.35 & .00 & .03 & 5.32 & 5.35 & .02 & 5.32 & 5.34 \\
\hline 05120115 & .01 & 1.14 & 1.15 & .23 & .24 & 1.14 & 1.38 & .13 & 1.14 & 1.27 \\
\hline 05140203 & .29 & .00 & .29 & .21 & .50 & .00 & .50 & .24 & .00 & .24 \\
\hline 05140204 & 1.54 & 1.55 & 3.09 & 5.75 & 7.29 & 1.55 & 8.84 & 3.48 & 1.55 & 5.03 \\
\hline 05140206 & .00 & .00 & .00 & .00 & .00 & .00 & .00 & .00 & .00 & .00 \\
\hline 07060005 & .00 & .00 & .00 & .00 & .00 & .00 & .00 & .00 & .00 & .00 \\
\hline 07080101 & .00 & .00 & .00 & .34 & .34 & .00 & .34 & .04 & .00 & .04 \\
\hline 07080104 & .00 & .00 & .00 & .00 & .00 & .00 & .00 & .00 & .00 & .0 \\
\hline 07090001 & .00 & .00 & .00 & .74 & .74 & .00 & .74 & .00 & .00 & .0 \\
\hline 07090003 & .26 & .00 & .26 & .00 & .26 & .00 & .26 & .04 & .00 & .04 \\
\hline 07090004 & .08 & .00 & .08 & .00 & .08 & .00 & .08 & .01 & .00 & .01 \\
\hline 07090005 & .61 & .00 & .61 & .01 & .62 & .00 & .62 & .09 & .00 & .09 \\
\hline 07090006 & .12 & .00 & .12 & 1.76 & 1.88 & .00 & 1.88 & .29 & .00 & .29 \\
\hline 07090007 & .00 & .00 & .00 & .02 & .02 & .00 & .02 & .00 & .00 & .00 \\
\hline 07110001 & .00 & .00 & .00 & .00 & .00 & .00 & .00 & .00 & .00 & .00 \\
\hline 07110004 & .00 & .00 & .00 & .00 & .00 & .00 & .00 & .00 & .00 & .00 \\
\hline 07110009 & .00 & .00 & .00 & .14 & .14 & .00 & .14 & .07 & .00 & .07 \\
\hline 07120001 & .79 & .00 & .79 & .00 & .79 & .00 & .79 & .12 & .00 & .12 \\
\hline 07120002 & .00 & .00 & .00 & .00 & .00 & .00 & .00 & .00 & .00 & .0 \\
\hline 07120003 & .03 & .00 & .03 & .28 & .31 & .00 & .31 & .05 & .00 & .0 \\
\hline 07120004 & .27 & .00 & .27 & .43 & .70 & .00 & .70 & .11 & .00 & .1 \\
\hline 07120005 & .02 & .00 & .02 & 2.49 & 2.51 & .00 & 2.51 & .38 & .00 & .3 \\
\hline 07120006 & .20 & .00 & .20 & 2.86 & 3.06 & .00 & 3.06 & .46 & .00 & .4 \\
\hline 07120007 & .05 & .00 & .05 & 7.90 & 7.95 & .00 & 7.95 & 1.22 & .00 & 1.2 \\
\hline 07130001 & .06 & .00 & .06 & 7.82 & 7.88 & .00 & 7.88 & 1.18 & .00 & 1.1 \\
\hline 07130002 & .03 & .00 & .03 & 4.37 & 4.40 & .00 & 4.40 & .66 & .00 & .6 \\
\hline 07130003 & .04 & .00 & .04 & .34 & .38 & .00 & .38 & .19 & .00 & .19 \\
\hline 07130004 & .00 & .00 & .00 & .00 & .00 & .00 & .00 & .00 & .00 & .0 \\
\hline 07130005 & .25 & .00 & .25 & .50 & .75 & .00 & .75 & .27 & .00 & .2 \\
\hline 07130006 & .00 & .01 & .01 & 1.49 & 1.49 & .01 & 1.50 & .24 & .01 & .2 \\
\hline 07130007 & .01 & .45 & .46 & .68 & .69 & .45 & 1.14 & .19 & .45 & .64 \\
\hline 07130008 & .00 & .00 & .00 & .42 & .42 & .00 & .42 & .06 & .00 & .06 \\
\hline 07130009 & .23 & .00 & .23 & .15 & .38 & .00 & .38 & .18 & .00 & .18 \\
\hline 07130010 & .00 & .00 & .00 & .48 & .48 & .00 & .48 & .23 & .00 & .2 \\
\hline 07130011 & .00 & .00 & .00 & .12 & .12 & .00 & .12 & .06 & .00 & .06 \\
\hline 07130012 & .00 & .00 & .00 & 1.13 & 1.13 & .00 & 1.13 & .56 & .00 & .56 \\
\hline 07140101 & .00 & .00 & .00 & .92 & .92 & .00 & .92 & .45 & .00 & .45 \\
\hline 07140105 & .02 & .00 & .02 & .46 & .48 & .00 & .48 & .23 & .00 & .2 \\
\hline 07140106 & 1.23 & 1.20 & 2.43 & 11.13 & 12.36 & 1.20 & 13.56 & 6.08 & 1.20 & 7.2 \\
\hline 07140108 & .00 & .00 & .00 & .00 & .00 & .00 & .00 & .00 & .00 & .00 \\
\hline 07140201 & .00 & .04 & .04 & .95 & .95 & .04 & .99 & .18 & .04 & .22 \\
\hline 07140202 & .08 & 2.32 & 2.40 & .66 & .74 & 2.32 & 3.06 & .36 & 2.32 & 2.68 \\
\hline 07140203 & .05 & .03 & .08 & .49 & .54 & .03 & .57 & .27 & .03 & .30 \\
\hline 07140204 & .27 & .15 & .42 & 2.43 & 2.70 & .15 & 2.85 & 1.23 & .15 & 1.38 \\
\hline Total & 7.55 & 25.47 & 33.02 & 61.23 & 68.78 & 25.47 & 94.25 & 20.45 & 25.47 & 45.92 \\
\hline
\end{tabular}


Table 13. Thermoelectric-power self-supplied withdrawals, deliveries from public-supply facilities for thermoelectric-power generation, consumptive use, and power generated in Illinois, by county, 1990

[Mgal/d, million gallons per day; GWh, gigawatt-hour]

\begin{tabular}{|c|c|c|c|c|c|c|c|}
\hline \multirow[b]{2}{*}{ County } & \multicolumn{3}{|c|}{$\begin{array}{l}\text { Self-supplied } \\
\text { withdrawals, } \\
\text { in MgaVd }\end{array}$} & \multirow{2}{*}{$\begin{array}{c}\text { Deliveries } \\
\text { from public- } \\
\text { water facilities, } \\
\text { in Mgal/d } \\
\end{array}$} & \multirow{2}{*}{$\begin{array}{c}\text { Total } \\
\text { self-supplied } \\
\text { withdrawals } \\
\text { and deliveries, } \\
\text { in Mgal/d } \\
\end{array}$} & \multirow{2}{*}{$\begin{array}{c}\text { Consumptive } \\
\text { use, } \\
\text { in Mgal/d }\end{array}$} & \multirow{2}{*}{$\begin{array}{c}\text { Power } \\
\text { generated, } \\
\text { in GWh } \\
\end{array}$} \\
\hline & $\begin{array}{c}\text { Ground } \\
\text { water }\end{array}$ & $\begin{array}{c}\text { Surface } \\
\text { water }\end{array}$ & Total & & & & \\
\hline Adams & 0.00 & 0.00 & 0.00 & 0.00 & 0.00 & 0.00 & 0.00 \\
\hline Alexander & .00 & .00 & .00 & .00 & .00 & .00 & .00 \\
\hline Bond & .00 & .00 & .00 & .00 & .00 & .00 & .00 \\
\hline Boone & .00 & .00 & .00 & .00 & .00 & .00 & .00 \\
\hline Brown & .00 & .00 & .00 & .00 & .00 & .00 & .00 \\
\hline Bureau & .00 & .00 & .00 & .00 & .00 & .00 & .00 \\
\hline Calhoun & .00 & .00 & .00 & .00 & .00 & .00 & .00 \\
\hline Carroll & .00 & .00 & .00 & .00 & .00 & .00 & .00 \\
\hline Cass & .00 & .00 & .00 & .00 & .00 & .00 & .00 \\
\hline Champaign & .00 & .00 & .00 & .00 & .00 & .00 & .00 \\
\hline Christian & .00 & 793.43 & 793.43 & .00 & 793.43 & 7.93 & $4,489.00$ \\
\hline Clark & .00 & .00 & .00 & .00 & .00 & .00 & .00 \\
\hline Clay & .00 & .00 & .00 & .00 & .00 & .00 & .00 \\
\hline Clinton & .00 & .00 & .00 & .00 & .00 & .00 & .00 \\
\hline Coles & .00 & .00 & .00 & .00 & .00 & .00 & .00 \\
\hline Cook & .00 & 409.64 & 409.64 & .43 & 410.07 & 4.09 & 861.72 \\
\hline Crawford & .76 & 58.66 & 59.42 & .00 & 59.42 & .61 & 408.14 \\
\hline Cumberland & .00 & .00 & .00 & .00 & .00 & .00 & .00 \\
\hline De Kalb & .00 & .00 & .00 & .00 & .00 & .00 & .00 \\
\hline De Witt & .00 & 493.18 & 493.18 & .00 & 493.18 & 14.79 & $3,051.00$ \\
\hline Douglas & .00 & .00 & .00 & .00 & .00 & .00 & .00 \\
\hline Du Page & .01 & .00 & .01 & .00 & .01 & .00 & .00 \\
\hline Edgar & .00 & .00 & .00 & .00 & .00 & .00 & .00 \\
\hline Edwards & .00 & .00 & .00 & .00 & .00 & .00 & .00 \\
\hline Effingham & .00 & .00 & .00 & .00 & .00 & .00 & .00 \\
\hline Fayette & .00 & .00 & .00 & .00 & .00 & .00 & .00 \\
\hline Ford & .00 & .00 & .00 & .00 & .00 & .00 & .00 \\
\hline Franklin & .00 & .00 & .00 & .00 & .00 & .00 & .00 \\
\hline Fulton & .00 & 267.99 & 267.99 & .00 & 267.99 & 8.04 & $1,880.21$ \\
\hline Gallatin & .00 & .00 & .00 & .00 & .00 & .00 & .00 \\
\hline Greene & .00 & .00 & .00 & .00 & .00 & .00 & .00 \\
\hline Grundy & .85 & $1,537.09$ & $1,537.94$ & .00 & $1,537.94$ & 30.83 & $10,173.77$ \\
\hline Hamilton & .00 & .00 & .00 & .00 & .00 & .00 & .00 \\
\hline Hancock & .00 & .00 & .00 & .00 & .00 & .00 & .00 \\
\hline Hardin & .00 & .00 & .00 & .00 & .00 & .00 & .00 \\
\hline Henderson & .00 & .00 & .00 & .00 & .00 & .00 & .00 \\
\hline Henry & .00 & .00 & .00 & .00 & .00 & .00 & .00 \\
\hline Iroquois & .00 & .00 & .00 & .00 & .00 & .00 & .00 \\
\hline Jackson & .09 & 142.76 & 142.85 & .00 & 142.85 & 1.48 & 386.00 \\
\hline Jasper & .00 & 419.18 & 419.18 & .00 & 419.18 & 3.45 & $4,756.00$ \\
\hline Jefferson & .00 & .00 & .00 & .00 & .00 & .00 & .00 \\
\hline Jersey & .00 & .00 & .00 & .00 & .00 & .00 & .00 \\
\hline Jo Daviess & .00 & .00 & .00 & .00 & .00 & .00 & .00 \\
\hline Johnson & .00 & .00 & .00 & .00 & .00 & .00 & .00 \\
\hline Kane & .00 & .00 & .00 & .00 & .00 & .00 & .00 \\
\hline Kankakee & .00 & .00 & .00 & .00 & .00 & .00 & .00 \\
\hline Kendall & .00 & .00 & .00 & .00 & .00 & .00 & .00 \\
\hline Knox & .00 & .00 & .00 & .00 & .00 & .00 & .00 \\
\hline Lake & .00 & $2,789.62$ & $2,789.62$ & .04 & $2,789.66$ & 70.92 & $10,076.00$ \\
\hline La Salle & .24 & 63.14 & 630.38 & .00 & 630.38 & 63.04 & $13,170.00$ \\
\hline
\end{tabular}


Table 13. Thermoelectric-power self-supplied withdrawals, deliveries from public-supply facilities for thermoelectric-power generation, consumptive use, and power generated in Illinois, by county, 1990-Continued

\begin{tabular}{|c|c|c|c|c|c|c|c|}
\hline County & $\begin{array}{c}\text { Ground } \\
\text { water }\end{array}$ & $\begin{array}{c}\begin{array}{c}\text { Self-suppli } \\
\text { withdrawa } \\
\text { in Mgal/c }\end{array} \\
\begin{array}{c}\text { Surface } \\
\text { water }\end{array} \\
\end{array}$ & Total & $\begin{array}{c}\text { Deliveries } \\
\text { from public- } \\
\text { water facilities, } \\
\text { in Mgal/d }\end{array}$ & $\begin{array}{c}\text { Total } \\
\text { self-supplied } \\
\text { withdrawals } \\
\text { and deliveries, } \\
\text { in Mgal/d }\end{array}$ & $\begin{array}{c}\text { Consumptive } \\
\text { use, } \\
\text { in Mgal/d } \\
\end{array}$ & $\begin{array}{c}\text { Power } \\
\text { generated, } \\
\text { in GWh }\end{array}$ \\
\hline $\begin{array}{l}\text { Lawrence } \\
\text { Lee } \\
\text { Livingston } \\
\text { Logan } \\
\text { McDonough }\end{array}$ & $\begin{array}{r}0.00 \\
.00 \\
.00 \\
.00 \\
.00\end{array}$ & $\begin{array}{l}0.00 \\
.00 \\
.00 \\
.00 \\
.00\end{array}$ & $\begin{array}{l}0.00 \\
.00 \\
.00 \\
.00 \\
.00\end{array}$ & $\begin{array}{r}0.00 \\
.00 \\
.00 \\
.00 \\
.00\end{array}$ & $\begin{array}{r}0.00 \\
.00 \\
.00 \\
.00 \\
.00\end{array}$ & $\begin{array}{r}0.00 \\
.00 \\
.00 \\
.00 \\
.00\end{array}$ & $\begin{array}{r}0.00 \\
.00 \\
.00 \\
.00 \\
.00\end{array}$ \\
\hline $\begin{array}{l}\text { McHenry } \\
\text { McLean } \\
\text { Macon } \\
\text { Macoupin } \\
\text { Madison }\end{array}$ & $\begin{array}{l}.00 \\
.00 \\
.00 \\
.00 \\
.00\end{array}$ & $\begin{array}{r}.00 \\
.00 \\
.00 \\
.00 \\
257.32\end{array}$ & $\begin{array}{r}.00 \\
.00 \\
.00 \\
.00 \\
257.32\end{array}$ & $\begin{array}{l}.00 \\
.00 \\
.00 \\
.00 \\
.01\end{array}$ & $\begin{array}{r}.00 \\
.00 \\
.00 \\
.00 \\
257.33\end{array}$ & $\begin{array}{r}.00 \\
.00 \\
.00 \\
.00 \\
2.63\end{array}$ & $\begin{array}{r}.00 \\
.00 \\
.00 \\
.00 \\
1,705.00\end{array}$ \\
\hline $\begin{array}{l}\text { Marion } \\
\text { Marshall } \\
\text { Mason } \\
\text { Massac } \\
\text { Menard }\end{array}$ & $\begin{array}{l}.00 \\
.00 \\
.83 \\
.93 \\
.00\end{array}$ & $\begin{array}{r}.00 \\
.00 \\
102.00 \\
466.55 \\
.00\end{array}$ & $\begin{array}{r}.00 \\
.00 \\
102.83 \\
467.48 \\
.00\end{array}$ & $\begin{array}{l}.00 \\
.00 \\
.00 \\
.00 \\
.00\end{array}$ & $\begin{array}{r}.00 \\
.00 \\
102.83 \\
467.48 \\
.00\end{array}$ & $\begin{array}{r}.00 \\
.00 \\
1.85 \\
4.83 \\
.00\end{array}$ & $\begin{array}{r}.00 \\
.00 \\
1,722.00 \\
6,434.00 \\
.00\end{array}$ \\
\hline $\begin{array}{l}\text { Mercer } \\
\text { Monroe } \\
\text { Montgomery } \\
\text { Morgan } \\
\text { Moultrie }\end{array}$ & $\begin{array}{l}.00 \\
.00 \\
.00 \\
.07 \\
.00\end{array}$ & $\begin{array}{r}.00 \\
.00 \\
420.00 \\
136.44 \\
.00\end{array}$ & $\begin{array}{r}.00 \\
.00 \\
420.00 \\
136.51 \\
.00\end{array}$ & $\begin{array}{l}.00 \\
.00 \\
.02 \\
.00 \\
.00\end{array}$ & $\begin{array}{r}.00 \\
.00 \\
420.02 \\
136.51 \\
.00\end{array}$ & $\begin{array}{r}.00 \\
.00 \\
48.41 \\
1.43 \\
.00\end{array}$ & $\begin{array}{r}.00 \\
.00 \\
3,958.00 \\
1,066.70 \\
.00\end{array}$ \\
\hline $\begin{array}{l}\text { Ogle } \\
\text { Peoria } \\
\text { Perry } \\
\text { Piatt } \\
\text { Pike }\end{array}$ & $\begin{array}{l}.58 \\
.00 \\
.00 \\
.00 \\
.02\end{array}$ & $\begin{array}{r}57.26 \\
343.00 \\
.00 \\
.00 \\
13.61\end{array}$ & $\begin{array}{r}57.84 \\
343.00 \\
.00 \\
.00 \\
13.63\end{array}$ & $\begin{array}{l}.00 \\
.01 \\
.00 \\
.00 \\
.00\end{array}$ & $\begin{array}{r}57.84 \\
343.01 \\
.00 \\
.00 \\
13.63\end{array}$ & $\begin{array}{r}1.73 \\
3.43 \\
.00 \\
.00 \\
.13\end{array}$ & $\begin{array}{r}15,878.00 \\
3,183.44 \\
.00 \\
.00 \\
102.00\end{array}$ \\
\hline $\begin{array}{l}\text { Pope } \\
\text { Pulaski } \\
\text { Putnam } \\
\text { Randolph } \\
\text { Richland }\end{array}$ & $\begin{array}{l}.00 \\
.00 \\
.62 \\
.00 \\
.00\end{array}$ & $\begin{array}{r}.00 \\
.00 \\
170.96 \\
1,047.75 \\
.00\end{array}$ & $\begin{array}{r}.00 \\
.00 \\
171.58 \\
1,047.75 \\
.00\end{array}$ & $\begin{array}{l}.00 \\
.00 \\
.00 \\
.01 \\
.00\end{array}$ & $\begin{array}{r}.00 \\
.00 \\
171.58 \\
1,047.76 \\
.00\end{array}$ & $\begin{array}{r}.00 \\
.00 \\
2.33 \\
10.68 \\
.00\end{array}$ & $\begin{array}{r}.00 \\
.00 \\
1,535.00 \\
9,240.00 \\
.00\end{array}$ \\
\hline $\begin{array}{l}\text { Rock Island } \\
\text { St. Clair } \\
\text { Saline } \\
\text { Sangamon } \\
\text { Schuyler }\end{array}$ & $\begin{array}{r}1.89 \\
.00 \\
.00 \\
.00 \\
.00\end{array}$ & $\begin{array}{r}1.46 \\
.00 \\
.00 \\
204.58 \\
.00\end{array}$ & $\begin{array}{r}3.35 \\
.00 \\
.00 \\
204.58 \\
.00\end{array}$ & $\begin{array}{l}.00 \\
.00 \\
.00 \\
.79 \\
.00\end{array}$ & $\begin{array}{r}3.35 \\
.00 \\
.00 \\
205.37 \\
.00\end{array}$ & $\begin{array}{r}.10 \\
.00 \\
.00 \\
2.05 \\
.00\end{array}$ & $\begin{array}{r}10,500.00 \\
.00 \\
.00 \\
1,631.36 \\
.00\end{array}$ \\
\hline $\begin{array}{l}\text { Scott } \\
\text { Shelby } \\
\text { Stark } \\
\text { Stephenson } \\
\text { Tazewell }\end{array}$ & $\begin{array}{r}.00 \\
.00 \\
.00 \\
.00 \\
1.03\end{array}$ & $\begin{array}{r}.00 \\
.00 \\
.00 \\
.00 \\
764.38\end{array}$ & $\begin{array}{r}.00 \\
.00 \\
.00 \\
.00 \\
765.41\end{array}$ & $\begin{array}{l}.00 \\
.00 \\
.00 \\
.00 \\
.00\end{array}$ & $\begin{array}{r}.00 \\
.00 \\
.00 \\
.00 \\
765.41\end{array}$ & $\begin{array}{r}.00 \\
.00 \\
.00 \\
.00 \\
8.67\end{array}$ & $\begin{array}{r}.00 \\
.00 \\
.00 \\
.00 \\
3,822.75\end{array}$ \\
\hline $\begin{array}{l}\text { Union } \\
\text { Vermilion } \\
\text { Wabash } \\
\text { Warren } \\
\text { Washington }\end{array}$ & $\begin{array}{l}.00 \\
.00 \\
.00 \\
.00 \\
.00\end{array}$ & $\begin{array}{r}.00 \\
2.76 \\
.00 \\
.00 \\
.00\end{array}$ & $\begin{array}{r}.00 \\
2.76 \\
.00 \\
.00 \\
.00\end{array}$ & $\begin{array}{l}.00 \\
.00 \\
.00 \\
.00 \\
.00\end{array}$ & $\begin{array}{r}.00 \\
2.76 \\
.00 \\
.00 \\
.00\end{array}$ & $\begin{array}{r}.00 \\
2.76 \\
.00 \\
.00 \\
.00\end{array}$ & $\begin{array}{r}.00 \\
912.90 \\
.00 \\
.00 \\
.00\end{array}$ \\
\hline $\begin{array}{l}\text { Wayne } \\
\text { White } \\
\text { Whiteside } \\
\text { Will } \\
\text { Williamson }\end{array}$ & $\begin{array}{r}.00 \\
.00 \\
.00 \\
1.11 \\
.00\end{array}$ & $\begin{array}{r}.00 \\
.00 \\
.00 \\
3,560.03 \\
69.92\end{array}$ & $\begin{array}{r}.00 \\
.00 \\
.00 \\
3,561.14 \\
69.92\end{array}$ & $\begin{array}{l}.00 \\
.00 \\
.00 \\
.00 \\
.00\end{array}$ & $\begin{array}{r}.00 \\
.00 \\
.00 \\
3,561.14 \\
69.92\end{array}$ & $\begin{array}{r}.00 \\
.00 \\
.00 \\
73.52 \\
.65\end{array}$ & $\begin{array}{r}.00 \\
.00 \\
.00 \\
15,787.52 \\
1,164.37\end{array}$ \\
\hline $\begin{array}{l}\text { Winnebago } \\
\text { Woodford }\end{array}$ & $\begin{array}{l}.00 \\
.00 \\
\end{array}$ & $\begin{array}{l}.00 \\
.00 \\
\end{array}$ & $\begin{array}{l}.00 \\
.00 \\
\end{array}$ & $\begin{array}{l}.00 \\
.00 \\
\end{array}$ & $\begin{array}{l}.00 \\
.00\end{array}$ & $\begin{array}{l}.00 \\
.00 \\
\end{array}$ & $\begin{array}{l}.00 \\
.00 \\
\end{array}$ \\
\hline Total & 9.03 & $15,159.71$ & $15,168.74$ & 1.31 & $15,170.05$ & 370.38 & $127,894.88$ \\
\hline
\end{tabular}


Table 14. Thermoelectric-power self-supplied withdrawals, deliveries from public-supply facilities for thermoelectric-power generation, consumptive use, and power generated in Illinois, by hydrologic unit, 1990

[Mgal/d, million gallons per day; GWh, gigawatt-hour]

\begin{tabular}{|c|c|c|c|c|c|c|c|}
\hline \multirow[b]{2}{*}{$\begin{array}{l}\text { Hydrologic } \\
\text { unit }\end{array}$} & \multicolumn{3}{|c|}{$\begin{array}{l}\text { Self-supplied withdrawals, } \\
\text { in Mgal/d }\end{array}$} & \multirow{2}{*}{$\begin{array}{c}\text { Deliveries } \\
\text { from public- } \\
\text { water facilities, } \\
\text { in Mgal/d }\end{array}$} & \multirow{2}{*}{$\begin{array}{c}\text { Total self-supplied } \\
\text { withdrawals and } \\
\text { deliveries, } \\
\text { in Mgal/d } \\
\end{array}$} & \multirow[b]{2}{*}{$\begin{array}{c}\text { Consumptive use, } \\
\text { in Mgal/d }\end{array}$} & \multirow{2}{*}{$\begin{array}{c}\text { Power } \\
\text { generated, } \\
\text { in GWh } \\
\end{array}$} \\
\hline & $\begin{array}{l}\text { Ground } \\
\text { water }\end{array}$ & $\begin{array}{c}\text { Surface } \\
\text { water }\end{array}$ & Total & & & & \\
\hline 04040001 & 0.00 & 0.00 & 0.00 & 0.00 & 0.00 & 0.00 & 0.00 \\
\hline 04040002 & .00 & .00 & .00 & .00 & .00 & .00 & .00 \\
\hline 04060200 & .00 & $2,789.62$ & $2,789.62$ & .04 & $2,789.66$ & 70.92 & $10,076.00$ \\
\hline 05120108 & .00 & .00 & .00 & .00 & .00 & .00 & .00 \\
\hline 05120109 & .00 & 2.76 & 2.76 & .00 & 2.76 & 2.76 & 912.90 \\
\hline 05120111 & .76 & 58.66 & 59.42 & .00 & 59.42 & .61 & 408.14 \\
\hline 05120112 & .00 & .00 & .00 & .00 & .00 & .00 & .00 \\
\hline 05120113 & .00 & .00 & .00 & .00 & .00 & .00 & .00 \\
\hline 05120114 & .00 & 419.18 & 419.18 & .00 & 419.18 & 3.45 & $4,756.00$ \\
\hline 05120115 & .00 & .00 & .00 & .00 & .00 & .00 & .00 \\
\hline 05140203 & .00 & .00 & .00 & .00 & .00 & .00 & .00 \\
\hline 05140204 & .00 & 69.92 & 69.92 & .00 & 69.92 & .65 & $1,164.37$ \\
\hline 05140206 & .93 & 466.55 & 467.48 & .00 & 467.48 & 4.83 & $6,434.00$ \\
\hline 07060005 & .00 & .00 & .00 & .00 & .00 & .00 & .00 \\
\hline 07080101 & 1.89 & 1.46 & 3.35 & .00 & 3.35 & .10 & $10,500.00$ \\
\hline 07080104 & .00 & .00 & .00 & .00 & .00 & .00 & .00 \\
\hline 07090001 & .00 & .00 & .00 & .00 & .00 & .00 & .00 \\
\hline 07090003 & .00 & .00 & .00 & .00 & .00 & .00 & .00 \\
\hline 07090004 & .00 & .00 & .00 & .00 & .00 & .00 & .00 \\
\hline 07090005 & .58 & 57.26 & 57.84 & .00 & 57.84 & 1.73 & $15,878.00$ \\
\hline 07090006 & .00 & .00 & .00 & .00 & .00 & .00 & .00 \\
\hline 07090007 & .00 & .00 & .00 & .00 & .00 & .00 & .00 \\
\hline 07110001 & .00 & .00 & .00 & .00 & .00 & .00 & .00 \\
\hline 07110004 & .00 & .00 & .00 & .00 & .00 & .00 & .00 \\
\hline 07110009 & .00 & 218.96 & 218.96 & .01 & 218.97 & 2.25 & $1,686.00$ \\
\hline 07120001 & .10 & 767.99 & 768.09 & .00 & 768.09 & 22.11 & $10,173.11$ \\
\hline 07120002 & .00 & .00 & .00 & .00 & .00 & .00 & .00 \\
\hline 07120003 & .00 & 20.34 & 20.34 & .19 & 20.53 & 2.00 & 398.75 \\
\hline 07120004 & 1.11 & $1,862.91$ & $1,864.02$ & .24 & $1,864.26$ & 19.22 & $11,359.49$ \\
\hline 07120005 & 1.00 & $3,305.65$ & $3,306.65$ & .00 & $3,306.65$ & 128.15 & $18,061.66$ \\
\hline 07120006 & .00 & .00 & .00 & .00 & .00 & .00 & .00 \\
\hline 07120007 & .01 & .00 & .01 & .00 & .01 & .00 & .00 \\
\hline 07130001 & .62 & 17.96 & 171.58 & .00 & 171.58 & 2.33 & $1,535.00$ \\
\hline 07130002 & .00 & .00 & .00 & .00 & .00 & .00 & .00 \\
\hline 07130003 & 1.85 & $1,477.38$ & $1,479.23$ & .01 & $1,479.24$ & 21.99 & $10,608.40$ \\
\hline 07130004 & .00 & .00 & .00 & .00 & .00 & .00 & .00 \\
\hline 07130005 & .00 & .00 & .00 & .00 & .00 & .00 & .00 \\
\hline 07130006 & .00 & .00 & .00 & .00 & .00 & .00 & .00 \\
\hline 07130007 & .00 & 998.01 & 998.01 & .79 & 998.80 & 9.98 & $6,120.36$ \\
\hline 07130008 & .00 & .00 & .00 & .00 & .00 & .00 & .00 \\
\hline 07130009 & .00 & 493.18 & 493.18 & .00 & 493.18 & 14.79 & $3,051.00$ \\
\hline 07130010 & .00 & .00 & .00 & .00 & .00 & .00 & .00 \\
\hline 07130011 & .09 & 15.05 & 15.14 & .00 & 15.14 & 1.56 & $1,168.70$ \\
\hline 07130012 & .00 & .00 & .00 & .00 & .00 & .00 & .00 \\
\hline 07140101 & .00 & 38.36 & 38.36 & .00 & 38.36 & .38 & 19.00 \\
\hline 07140105 & .09 & 142.76 & 142.85 & .00 & 142.85 & 1.48 & 386.00 \\
\hline 07140106 & .00 & .00 & .00 & .00 & .00 & .00 & .00 \\
\hline 07140108 & .00 & .00 & .00 & .00 & .00 & .00 & .00 \\
\hline 07140201 & .00 & .00 & .00 & .00 & .00 & .00 & .00 \\
\hline 07140202 & .00 & .00 & .00 & .00 & .00 & .00 & .00 \\
\hline 07140203 & .00 & 420.00 & 420.00 & .02 & 420.02 & 48.41 & $3,958.00$ \\
\hline 07140204 & .00 & $1,047.75$ & $1,047.75$ & .01 & $1,047.76$ & 1.68 & $9,240.00$ \\
\hline Total & 9.03 & $\overline{15,159.71}$ & $\overline{15,168.74}$ & 1.31 & $15,170.05$ & 37.38 & $\overline{127,894.88}$ \\
\hline
\end{tabular}


Table 15. Total withdrawals in Illinois, by county, 1990 [All values are in million gallons per day]

\begin{tabular}{|c|c|c|c|c|c|c|c|}
\hline \multirow[b]{3}{*}{ County } & \multicolumn{7}{|c|}{ Withdrawals } \\
\hline & \multicolumn{3}{|c|}{ Ground water } & \multirow{2}{*}{$\begin{array}{c}\begin{array}{c}\text { Surface } \\
\text { water }\end{array} \\
\end{array}$} & \multicolumn{3}{|c|}{ Total } \\
\hline & Fresh & Saline & Total & & Fresh & Sailine & Total \\
\hline Adams & 13.60 & 0.00 & 13.60 & 7.06 & 20.66 & 0.00 & 20.66 \\
\hline Alexander & .91 & .00 & .91 & 1.42 & 2.33 & .00 & 2.33 \\
\hline Bond & 1.08 & .00 & 1.08 & .94 & 2.02 & .00 & 2.02 \\
\hline Boone & 5.61 & .00 & 5.61 & .00 & 5.61 & .00 & 5.61 \\
\hline Brown & .60 & .00 & .60 & .00 & .60 & .00 & .60 \\
\hline Bureau & 6.17 & .00 & 6.17 & .28 & 6.45 & .00 & 6.45 \\
\hline Calhoun & 1.50 & .00 & 1.50 & 9.08 & 10.58 & .00 & 10.58 \\
\hline Carroll & 4.50 & .00 & 4.50 & 7.86 & 12.36 & .00 & 12.36 \\
\hline Cass & 6.47 & .00 & 6.47 & .25 & 6.72 & .00 & 6.72 \\
\hline Champaign & 29.15 & .00 & 29.15 & 5.23 & 34.38 & .00 & 34.38 \\
\hline Christian & 2.27 & .46 & 2.73 & 795.81 & 798.08 & .46 & 798.54 \\
\hline Clark & 4.18 & .11 & 4.29 & .00 & 4.18 & .11 & 4.29 \\
\hline Clay & .70 & .72 & 1.42 & .90 & 1.60 & .72 & 2.32 \\
\hline Clinton & 2.73 & .31 & 3.04 & 3.41 & 6.14 & .31 & 6.45 \\
\hline Coles & 1.50 & .12 & 1.62 & 4.20 & 5.70 & .12 & 5.82 \\
\hline Cook & 48.06 & .00 & 48.06 & $1,742.94$ & $1,791.00$ & .00 & $1,791.00$ \\
\hline Crawford & 3.84 & 3.60 & 7.44 & 62.92 & 66.76 & 3.60 & 70.36 \\
\hline Cumberland & 1.14 & .11 & 1.25 & .02 & 1.16 & .11 & 1.27 \\
\hline De Kalb & 11.58 & .00 & 11.58 & 2.93 & 14.51 & .00 & 14.51 \\
\hline De Witt & 3.00 & .00 & 3.00 & 493.37 & 496.37 & .00 & 496.37 \\
\hline Douglas & 2.08 & .00 & 2.08 & 5.75 & 7.83 & .00 & 7.83 \\
\hline Du Page & 99.63 & .00 & 99.63 & 4.91 & 104.54 & .00 & 104.54 \\
\hline Edgar & 1.24 & .09 & 1.33 & 1.20 & 2.44 & .09 & 2.53 \\
\hline Edwards & .78 & .49 & 1.27 & .12 & .90 & .49 & 1.39 \\
\hline Effingham & 2.01 & .22 & 2.23 & 2.29 & 4.30 & .22 & 4.52 \\
\hline Fayette & 1.51 & 1.28 & 2.79 & 5.35 & 6.86 & 1.28 & 8.14 \\
\hline Ford & 2.23 & .00 & 2.23 & .04 & 2.27 & .00 & 2.27 \\
\hline Franklin & .79 & .23 & 1.02 & 15.34 & 16.13 & .23 & 16.36 \\
\hline Fulton & 3.01 & .00 & 3.01 & 272.65 & 275.66 & .00 & 275.66 \\
\hline Gallatin & 7.70 & .27 & 7.97 & 1.23 & 8.93 & .27 & 9.20 \\
\hline Greene & 1.78 & .00 & 1.78 & .30 & 2.08 & .00 & 2.08 \\
\hline Grundy & 10.66 & .00 & 10.66 & $1,537.16$ & $1,547.82$ & .00 & $1,547.82$ \\
\hline Hamilton & .68 & .51 & 1.19 & .35 & 1.03 & .51 & 1.54 \\
\hline Hancock & 2.36 & .00 & 2.36 & 1.04 & 3.40 & .00 & 3.40 \\
\hline Hardin & 1.44 & .00 & 1.44 & .18 & 1.62 & .00 & 1.62 \\
\hline Henderson & 8.09 & .00 & 8.09 & .00 & 8.09 & .00 & 8.09 \\
\hline Henry & 8.96 & .00 & 8.96 & .00 & 8.96 & .00 & 8.96 \\
\hline Iroquois & 3.88 & .00 & 3.88 & .08 & 3.96 & .00 & 3.96 \\
\hline Jackson & 25.56 & .00 & 25.56 & 152.41 & 177.97 & .00 & 177.97 \\
\hline Jasper & 1.49 & 1.10 & 2.59 & 419.19 & 420.68 & 1.10 & 421.78 \\
\hline Jefferson & 1.07 & .77 & 1.84 & 4.00 & 5.07 & .77 & 5.84 \\
\hline Jersey & 1.45 & .00 & 1.45 & 7.35 & 8.80 & .00 & 8.80 \\
\hline Jo Daviess & 7.09 & .00 & 7.09 & .08 & 7.17 & .00 & 7.17 \\
\hline Johnson & .80 & .00 & .80 & .64 & 1.44 & .00 & 1.44 \\
\hline Kane & 35.15 & .00 & 35.15 & 10.79 & 45.94 & .00 & 45.94 \\
\hline Kankakee & 9.35 & .00 & 9.35 & 11.34 & 20.69 & .00 & 20.69 \\
\hline Kendall & 5.41 & .00 & 5.41 & .00 & 5.41 & .00 & 5.41 \\
\hline Knox & 3.11 & .00 & 3.11 & .00 & 3.11 & .00 & 3.11 \\
\hline Lake & 31.48 & .00 & 31.48 & $2,842.93$ & $2,874.41$ & .00 & $2,874.41$ \\
\hline La Salle & 16.57 & .00 & 16.57 & 658.23 & 674.80 & .00 & 674.80 \\
\hline Lawrence & 5.39 & 7.22 & 12.61 & .00 & 5.39 & 7.22 & 12.61 \\
\hline Lee & 8.30 & .00 & 8.30 & .02 & 8.32 & .00 & 8.32 \\
\hline Livingston & 3.54 & .00 & 3.54 & 2.16 & 5.70 & .00 & 5.70 \\
\hline Logan & 4.58 & .00 & 4.58 & .11 & 4.69 & .00 & 4.69 \\
\hline McDonough & 2.46 & .00 & 2.46 & 2.31 & 4.77 & .00 & 4.77 \\
\hline
\end{tabular}


Table 15. Total withdrawals in llinois, by county-Continued

\begin{tabular}{|c|c|c|c|c|c|c|c|}
\hline \multirow[b]{3}{*}{ County } & \multicolumn{7}{|c|}{ Withdrawals } \\
\hline & \multicolumn{3}{|c|}{ Ground water } & \multirow{2}{*}{$\begin{array}{c}\begin{array}{c}\text { Surface } \\
\text { water }\end{array} \\
\end{array}$} & \multicolumn{3}{|c|}{ Total } \\
\hline & Fresh & Saline & Total & & Fresh & Saline & Total \\
\hline McHenry & 25.81 & 0.00 & 25.81 & 4.07 & 29.88 & 0.00 & 29.88 \\
\hline McLean & 7.84 & .00 & 7.84 & 3.38 & 11.22 & .00 & 11.22 \\
\hline Macon & 2.27 & .00 & 2.27 & 41.07 & 43.34 & .00 & 43.34 \\
\hline Macoupin & 2.16 & .00 & 2.16 & 5.29 & 7.45 & .00 & 7.45 \\
\hline Madison & 51.32 & .09 & 51.41 & 323.39 & 374.71 & .09 & 374.80 \\
\hline Marion & .96 & .65 & 1.61 & 6.90 & 7.86 & .65 & 8.51 \\
\hline Marshall & 3.91 & .00 & 3.91 & .01 & 3.92 & .00 & 3.92 \\
\hline Mason & 36.44 & .00 & 36.44 & 102.00 & 138.44 & .00 & 138.44 \\
\hline Massac & 10.23 & .00 & 10.23 & 466.58 & 476.81 & .00 & 476.81 \\
\hline Menard & 1.53 & .00 & 1.53 & .00 & 1.53 & .00 & 1.53 \\
\hline Mercer & 3.30 & .00 & 3.30 & .00 & 3.30 & .00 & 3.30 \\
\hline Monroe & 1.70 & .00 & 1.70 & .75 & 2.45 & .00 & 2.45 \\
\hline Montgomery & 2.11 & .00 & 2.11 & 422.82 & 424.93 & .00 & 424.93 \\
\hline Morgan & 5.46 & .00 & 5.46 & 137.13 & 142.59 & .00 & 142.59 \\
\hline Moultrie & 1.58 & .00 & 1.58 & .99 & 2.57 & .00 & 2.57 \\
\hline Ogle & 10.94 & .00 & 10.94 & 57.26 & 68.20 & .00 & 68.20 \\
\hline Peoria & 36.52 & .00 & 36.52 & 361.86 & 398.38 & .00 & 398.38 \\
\hline Perry & 2.45 & .01 & 2.46 & 8.37 & 10.82 & .01 & 10.83 \\
\hline Piatt & 3.35 & .00 & 3.35 & .00 & 3.35 & .00 & 3.35 \\
\hline Pike & 3.25 & .00 & 3.25 & 14.12 & 17.37 & .00 & 17.37 \\
\hline Pope & .18 & .00 & .18 & .08 & .26 & .00 & .26 \\
\hline Pulaski & 1.06 & .00 & 1.06 & .00 & 1.06 & .00 & 1.06 \\
\hline Putnam & 1.68 & .00 & 1.68 & 176.05 & 177.73 & .00 & 177.73 \\
\hline Randolph & 2.00 & .00 & 2.00 & $1,051.25$ & $1,053.25$ & .00 & $1,053.25$ \\
\hline Richland & .75 & .91 & 1.66 & 1.45 & 2.20 & .91 & 3.11 \\
\hline Rock Island & 19.30 & .00 & 19.30 & 52.88 & 72.18 & .00 & 72.18 \\
\hline St. Clair & 14.96 & .00 & 14.96 & 22.35 & 37.31 & .00 & 37.31 \\
\hline Saline & .41 & .35 & .76 & 4.12 & 4.53 & .35 & 4.88 \\
\hline Sangamon & 4.31 & .00 & 4.31 & 237.33 & 241.64 & .00 & 241.64 \\
\hline Schuyler & 1.28 & .00 & 1.28 & .06 & 1.34 & .00 & 1.34 \\
\hline Scott & 2.53 & .00 & 2.53 & .02 & 2.55 & .00 & 2.55 \\
\hline Shelby & 3.01 & .04 & 3.05 & 1.50 & 4.51 & .04 & 4.55 \\
\hline Stark & 1.11 & .00 & 1.11 & .00 & 1.11 & .00 & 1.11 \\
\hline Stephenson & 9.96 & .00 & 9.96 & .00 & 9.96 & .00 & 9.96 \\
\hline Tazewell & 30.55 & .00 & 30.55 & 782.40 & 812.95 & .00 & 812.95 \\
\hline Union & 2.92 & .00 & 2.92 & .21 & 3.13 & .00 & 3.13 \\
\hline Vermilion & 6.09 & .00 & 6.09 & 12.76 & 18.85 & .00 & 18.85 \\
\hline Wabash & 1.46 & 1.23 & 2.69 & 1.13 & 2.59 & 1.23 & 3.82 \\
\hline Warren & 3.57 & .00 & 3.57 & .00 & 3.57 & .00 & 3.57 \\
\hline Washington & 1.32 & .35 & 1.67 & 1.09 & 2.41 & .35 & 2.76 \\
\hline Wayne & 1.58 & 1.71 & 3.29 & 1.30 & 2.88 & 1.71 & 4.59 \\
\hline White & 6.76 & 2.49 & 9.25 & .09 & 6.85 & 2.49 & 9.34 \\
\hline Whiteside & 16.86 & .00 & 16.86 & 4.23 & 21.09 & .00 & 21.09 \\
\hline Will & 50.99 & .00 & 50.99 & $3,577.28$ & $3,628.27$ & .00 & $3,628.27$ \\
\hline Williamson & .33 & .03 & .36 & 82.55 & 82.88 & .03 & 82.91 \\
\hline Winnebago & 48.09 & .00 & 48.09 & .82 & 48.91 & .00 & 48.91 \\
\hline Woodford & 3.41 & .00 & 3.41 & 5.72 & 9.13 & .00 & 9.13 \\
\hline Total & 919.82 & 25.47 & 945.29 & $\overline{17,070.83}$ & $1,799.65$ & 25.47 & $18,016.12$ \\
\hline
\end{tabular}


Table 16. Total withdrawals in Illinois, by hydrologic unit, 1990 [All values are in million gallons per day]

\begin{tabular}{|c|c|c|c|c|c|c|c|}
\hline \multirow{3}{*}{$\begin{array}{l}\text { Hydrologic } \\
\text { unit }\end{array}$} & \multicolumn{7}{|c|}{ Withdrawals } \\
\hline & \multicolumn{3}{|c|}{ Ground water } & \multirow{2}{*}{$\begin{array}{c}\text { Surface } \\
\text { water }\end{array}$} & \multicolumn{3}{|c|}{ Total } \\
\hline & Fresh & Saline & Total & & Fresh & Saline & Total \\
\hline 04040001 & 0.02 & 0.00 & 0.02 & 35.80 & 35.82 & 0.00 & 35.82 \\
\hline 04040002 & 1.66 & .00 & 1.66 & 83.92 & 85.58 & .00 & 85.58 \\
\hline 04060200 & .00 & .00 & .00 & $3,947.56$ & $3,947.56$ & .00 & $3,947.56$ \\
\hline 05120108 & .42 & .00 & .42 & .49 & .91 & .00 & .91 \\
\hline 05120109 & 11.20 & .00 & 11.20 & 14.71 & 25.91 & .00 & 25.91 \\
\hline 05120111 & 6.13 & .05 & 6.18 & 64.12 & 70.25 & .05 & 70.30 \\
\hline 05120112 & 12.71 & 10.66 & 23.37 & 2.63 & 15.34 & 10.66 & 26.00 \\
\hline 05120113 & 5.36 & 2.55 & 7.91 & 1.40 & 6.76 & 2.55 & 9.31 \\
\hline 05120114 & 7.46 & 5.32 & 12.78 & 427.51 & 434.97 & 5.32 & 440.29 \\
\hline 05120115 & 2.44 & 1.14 & 3.58 & .50 & 2.94 & 1.14 & 4.08 \\
\hline 05140203 & 2.32 & .00 & 2.32 & .48 & 2.80 & .00 & 2.80 \\
\hline 05140204 & 9.11 & 1.55 & 10.66 & 76.82 & 85.93 & 1.55 & 87.48 \\
\hline 05140206 & 11.29 & .00 & 11.29 & 468.64 & 479.93 & .00 & 479.93 \\
\hline 07060005 & 11.78 & .00 & 11.78 & 7.88 & 19.66 & .00 & 19.66 \\
\hline 07080101 & 16.27 & .00 & 16.27 & 52.90 & 69.17 & .00 & 69.17 \\
\hline 07080104 & 16.88 & .00 & 16.88 & .58 & 17.46 & .00 & 17.46 \\
\hline 07090001 & 1.19 & .00 & 1.19 & .74 & 1.93 & .00 & 1.93 \\
\hline 07090003 & 13.16 & .00 & 13.16 & .03 & 13.19 & .00 & 13.19 \\
\hline 07090004 & 1.44 & .00 & 1.44 & .01 & 1.45 & .00 & 1.45 \\
\hline 07090005 & 76.63 & .00 & 76.63 & 61.61 & 138.24 & .00 & 138.24 \\
\hline 07090006 & 25.92 & .00 & 25.92 & 3.28 & 29.20 & .00 & 29.20 \\
\hline 07090007 & 10.02 & .00 & 10.02 & .02 & 10.04 & .00 & 10.04 \\
\hline 07110001 & 12.27 & .00 & 12.27 & 7.23 & 19.50 & .00 & 19.50 \\
\hline 07110004 & 4.57 & .00 & 4.57 & 3.23 & 7.80 & .00 & 7.80 \\
\hline 07110009 & 18.27 & .00 & 18.27 & 232.44 & 250.71 & .00 & 250.71 \\
\hline 07120001 & 13.33 & .00 & 13.33 & 779.31 & 792.64 & .00 & 792.64 \\
\hline 07120002 & 5.10 & .00 & 5.10 & .09 & 5.19 & .00 & 5.19 \\
\hline 07120003 & 33.71 & .00 & 33.71 & 256.37 & 290.08 & .00 & 290.08 \\
\hline 07120004 & 168.90 & .00 & 168.90 & $1,935.95$ & $2,104.85$ & .00 & $2,104.85$ \\
\hline 07120005 & 17.90 & .00 & 17.90 & $3,309.67$ & $3,327.57$ & .00 & $3,327.57$ \\
\hline 07120006 & 38.96 & .00 & 38.96 & 3.02 & 41.98 & .00 & 41.98 \\
\hline 07120007 & 43.10 & .00 & 43.10 & 22.26 & 65.36 & .00 & 65.36 \\
\hline 07130001 & 38.72 & .00 & 38.72 & 197.85 & 236.57 & .00 & 236.57 \\
\hline 07130002 & 4.26 & .00 & 4.26 & 9.92 & 14.18 & .00 & 14.18 \\
\hline 07130003 & 67.40 & .00 & 67.40 & $1,506.90$ & $1,574.30$ & .00 & $1,574.30$ \\
\hline 07130004 & 9.32 & .00 & 9.32 & 9.63 & 18.95 & .00 & 18.95 \\
\hline 07130005 & 10.99 & .00 & 10.99 & .54 & 11.53 & .00 & 11.53 \\
\hline 07130006 & 10.55 & .01 & 10.56 & 42.58 & 53.13 & .01 & 53.14 \\
\hline 07130007 & 3.43 & .45 & 3.88 & $1,032.49$ & $1,035.92$ & .45 & $1,036.37$ \\
\hline 07130008 & 15.07 & .00 & 15.07 & .64 & 15.71 & .00 & 15.71 \\
\hline 07130009 & 19.37 & .00 & 19.37 & 493.52 & 512.89 & .00 & 512.89 \\
\hline 07130010 & 4.06 & .00 & 4.06 & 2.44 & 6.50 & .00 & 6.50 \\
\hline 07130011 & 12.64 & .00 & 12.64 & 164.61 & 177.25 & .00 & 177.25 \\
\hline 07130012 & 2.58 & .00 & 2.58 & 4.17 & 6.75 & .00 & 6.75 \\
\hline 07140101 & 45.93 & .00 & 45.93 & 109.17 & 155.10 & .00 & 155.10 \\
\hline 07140105 & 3.76 & .00 & 3.76 & 145.51 & 149.27 & .00 & 149.27 \\
\hline 07140106 & 29.81 & 1.20 & 31.01 & 48.22 & 78.03 & 1.20 & 79.23 \\
\hline 07140108 & 1.34 & .00 & 1.34 & .11 & 1.45 & .00 & 1.45 \\
\hline 07140201 & 26.64 & .04 & 26.68 & 8.80 & 35.44 & .04 & 35.48 \\
\hline 07140202 & 4.23 & 2.32 & 6.55 & 12.60 & 16.83 & 2.32 & 19.15 \\
\hline 07140203 & 3.03 & .03 & 3.06 & 424.69 & 427.72 & .03 & 427.75 \\
\hline 07140204 & 7.17 & .15 & 7.32 & $1,055.24$ & $1,062.41$ & .15 & $1,062.56$ \\
\hline Total & $\overline{919.82}$ & $\overline{25.47}$ & $\overline{945.29}$ & $\overline{1,707.83}$ & $\overline{17,990.65}$ & $\overline{25.47}$ & $\overline{18,016.12}$ \\
\hline
\end{tabular}

